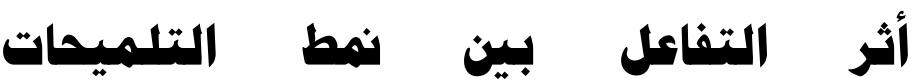
(الاكتوبة/اللونية) والأسلوب المعرفي في التعلم

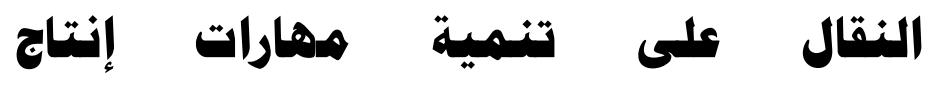
الإنفوجرافيك والتفكير الابتكاري لدى طلاب

\title{
تكنوالوجيا التمايسم
}

د/ هبه عثمان فؤاد العرب

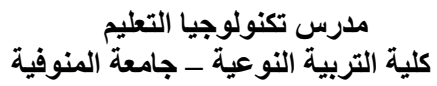

أ.م. أيمن فوزى خطاب هدكور

أستاذ مساعد تكنولوجيا التعليم كلية التربية النوعية - جامعة المنوفية
إنتاج الإنفوجرافيك الثابت باستخدام برنامج الفوتوشوب، والتفكير الابتكاري. تمثلت أدوات البحث في اختبار تحصيلي، بطاقة تقييم أداء مهارات إنتاج الإنفوجرافيك الثابت باستخدام برنامج الفوتوشوب، واختبار للتفير الابتكاري، وتكونت عينة البحث من 9ه طالبًا وطالبة وتم تقسيمهم إلي أربع مجموعات حسب الأسلوب المعرفي، وتم استخدام برنامج ال SPSS إلى: وجود تأثير عند تقديم نمطي التلميحات في التعلم النقال لصالح التلميحات المكتوبة وأنها أفضل من التلميحات اللونية على تتمية التحصيل الدراسي، والأداء المهاري، والتفكير الابتكاري؛ وأنه يوجد تأثثير أيضًا للأسلوب المعرفي في التعلم النقال لصالح الطلاب المعتمدون بأنهم أفضل من المستقلون عند تتمية التحصيل الدراسي، والأداء المهاري لايهم، ولا يوجد

\section{وستخاص البمث}

هدف البحث الحالي إلى الكثف عن دراسة أثز التفاعل بين نمط التلميحات (المكتوبة/اللونية) والأسلوب المعرفي (الأعتماد على المجال/الأستقلال عن المجال) في التعلم النقال على تتمية مهارات إنتاج الإنفوجرافيك الثابت باستخدام برنامـ الفوتوشوب والتفكير الابتكاري لاى طلاب تكنولوجيا التعليم بالفرقة الثانية بمقرر إنتاج الرسوم التعليمية. تم الإعتماد على التصميم التجريبي وهو التصميم العاملى البسيط (YXYY) الأي يهتم بقياس أثر متغيرين مستقلين، وهما نمط التلميحات (المكتوبة/اللونية)، والأسلوب المعرفي (الأعتماد على المجال/الأستقلال عن المجال) في التعلم التقال، على المتغيرات التابعة وهي الجوانب المعرفية، الجوانب الأدائية لمهارات

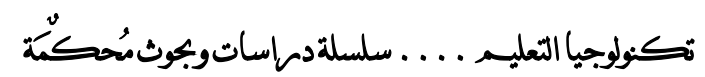


المحمولية، والتكنولوجيات اللاسلكية (محمد عطية، .* (1 194 ص r. 1)

التعلم النقـال هـو عبـارة عـن إيجـاد سـياقات

متعددة للتعلم الذي يوفر للمتعلم تفاعلًا مـع المحتوى

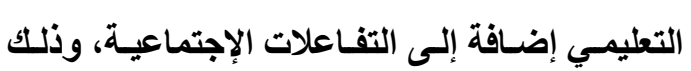
بالإعتمــاد عـى الأجهـزة الإكترونيـة الثخصـية اللاسلكية (Crompton, 2013, p.4). ويتميز بعدة إمكانيات وخصائص فريدة أهمها: تدعيم الأداء في أي مكسان وأي وقت، ويتيح استخدام الوسـائط المتعددة التي يمكن أن تغني وتثري المحتوى، يعد كوسيط اتصال لخلق المعرفة والذي يتيح من خلالهـ الوصـــول للخبــراء، بنـــاء مجتمعـــات للمعرفـــة و الممارسـة، سـب المطلومـات وتقديمها للمتعلمين في آن واحد، يسـاعد على توصيل المحتوى ومـواد

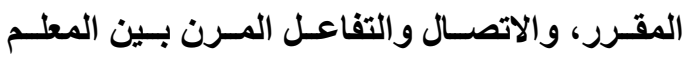
والمتعلمين في الواقع والفصول التقليديـة، وتميزه بالسـعة والسـرعة في إدارة الـتعلم والمطلومــات، و إمكانيـة المـتعلم الحصــول السـريع على خـدمات

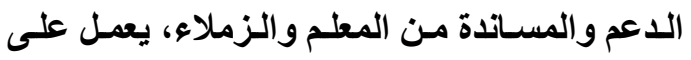
توفير المرونة في عملية التعلم ، وأيضًا يساعد على وهن توفير وقت التعلم وتسريعه. ويتسم أيضًا بخصائص هـي: الاتســاع والامتــداد، الـتعلم الــواري، تعـدـد أنشطة التعلم، الانفتاح على البيئة، التكيف، التعلم

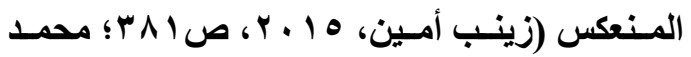

* اتبع الباحثان في التوثيق نظام جمعية علم النفس الأمريكية الإصدار السادس (APA 6ed).
تأثير للأسلوب المعرفي عند تنمية التفكير الابتكاري؛ ووجود تأثير للتفاعل بين نمطي التلميحات والأسلوب المعرفي في التعلم النقال على تتمية الأداء المهاري لصالح مجموعة ذوي أسلوب التعلم المعتمد مع التلميحات المكتوبة، ولا يوجد تأثير لهذا التفاعل عند تنمية التحصيل الدراسي، والتفكير الابتكاري. الكلمات المفتاحية: التعلم النقال، التلميحات، الأسلوب المعرفي، الإنفوجرافيك،

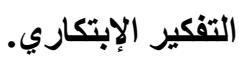

\section{هقدهة}

تلعبب تكنولوجيـا الـتعلم النقــال دورًا متزايـدًا الأهميـة فـي مجـال التعلـيم والـتعلم، وذلــك لتعزيـز

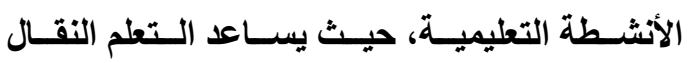
المتعلمين على تمكينهم مسن الوصسول إلى مصسادر

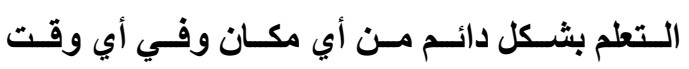

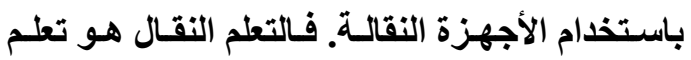
إلكترونـي ممتد إلى خـارج الجدران، ومـن ثم فهو

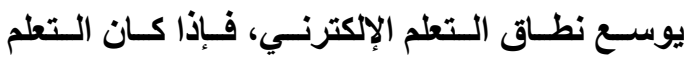
الإكتروني ينقل التعلم إلى خارج الفصول والقاعـات الاراسية، فإن التعلم النقال ينقل التعلم إلى أي مكان

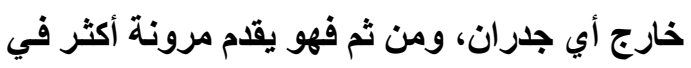
أي وقت وأي مكان، وهذه المرونة تحدث من خلال نظم وتكنولوجيا التوصيل بإستخدام الأجهزة الرقمية

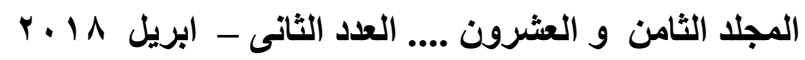


الجمعية المصرية لتكنولوجيا التعليم

(2011; Chen, Wang, \& Huang, 2008 الفوائـد التعليميـة السـابقة يعد التعلم النقـال مناسبًا لاستخدامه في تنميـة مهـارات إنتـاج الإنفوجر افيك والتفكير الابتكاري للى الطلاب حيث يقوم الطلاب بتحويـل البيانـات والمعلومــات المكتوبـه إلـى صـور ورسـومات عن طريق برامج الكمبيوتر، كبرنـامج الفوتوشوب أو الإليستريتور أو الفلاش أوغيرها من برامج الجرافيك المنتشرة. ويعد إنتاج الإنفوجرافيك

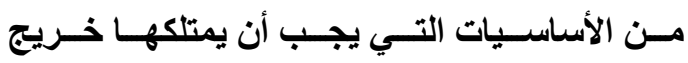
تكنولوجيا التعليم نظرًا لطبيعة العصر الذي نعيثـه لهـ اليـوم مـن تكـس البيانـات والمعلومــات المكتوبــة والتـي تعـد أحــ المشـكلات التربويـة التـي يقابلهـا المتعلمـون عنــــ دراسـتهم، ولــنلك فمـن واجبـات أخصـائي تكنولوجيا التعليم أن يقوم بحل مثل هذه المشكلات، وقد يكون لدى طلاب تكنولوجيا التعليم بعض المهارات الخاصـة بتصميم الجرافيك، ولكنهم غير قـادرين على توظيف مثل هذه المهارات في

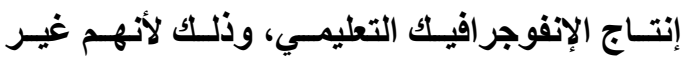

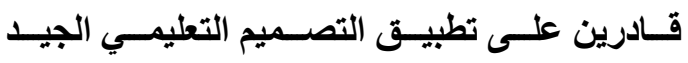
ومعاييره عند الإنتاج، وعدم قدرتهم على الوصول

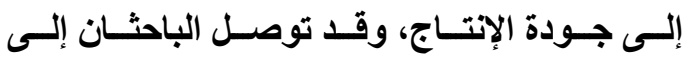
المشكلات المتعلقة بالإنتاج من خلال تطبيق دراسـة اسـتطلاعية على طـلاب تكنولوجيـا التعليم بمقرر إنتـاج الرسـوم التعليميـة، والتـي سـيرد ذكرهـا في مشـكلة البحثث. ووفقَـا لنتـائج البحـوث و الدراســات حول فاعلية التعلم النقال كمـا تم ذكره سـابقًا فيرى

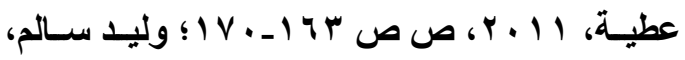
(IVT מ. (I) للتعلم النقال وظائف واستخد/مات عديدة، فهو يسـتخدم فـي: رفـع كفــاءة المتعلمـين فـي إنجـاز المشـروعات التعاونيـة، التحفيـز الإيجـابي للطـلاب نحسو الـتـلم، وزيــادة الأداء الأكسـاديمي، وتحسـين اتجاهاتهم الإيجابية نحو الأفضل، تنمية التفاعل بين المتعلمـين بعضــهم الـبعض فـي إنجـاز المهمــات التعليميـة، تنميـة التحصيل الدراسي والإنجـاز للدى الطلاب بكفاعة عاليـة، توفير المعلومـات والتوجيـه والإرشــاد متـى وأيـن تكـون الحاجـة إليهـا، تنميـة مهارات البحث العلمي للى طلاب الدراسـات العليا، تنمية مهارات الانخراط في التعليم، تنمية مهارات استخدام تطبيقات الهواتف الذكية لدى معلمي التعليم الأساسي، اكساب المتعلمين المفاهيم والمصطلحات التكنولوجيـة وتكوين اتجاهـات ايجابيـة للـيهم نحو التعلم النقال، وعلاج الأخطاء التدريسية الشائعة في تنفيـذ الـدرس للدى المعلمين. وقــ أثبتـت البحـوث فاعليـة اسـتخدامه (حمــادة محمـد، وأيمـن محمـد،

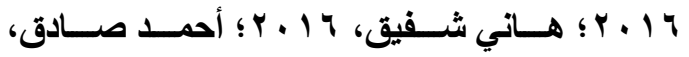
ه 1 ـ ب؛ محمــد دســوقي، ومصــطفى أبوالنــور، ـ ا ـ ب؛ رفيــق البربــري، وحنـــان عبدالســلام، Crompton, \& Burke, 2018; $\leqslant r+11$ Iglesias, García, \& Sánchez, 2017; Pimmer, Mateescu, \& Gröhbiel, 2016; Miliva, 2011; Chang, Wong, \& Chang,

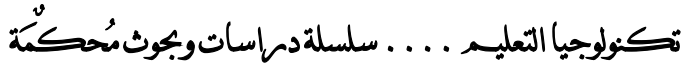


المألوفـة ســواء كانــت ذات طسابع خـاص أو تمثـل مفهومَّا عامًَا، ويسـاعد المتعلمين على الأحتفـاظ بمحتوى التقلم وزيادة التركيز، الأسـهام في توصيل الرســالة والهـدف التعليمسي بسـرعة نظـرًا لتركيـز المعلومات بشكل بصري، ويساعد في المساهمة في تكـوين تصــور عقلـي سـليم وتعـديل التصــورات الخاطئسة لـدى المتعلمسين (تـامر المفــاوري، وياسـر

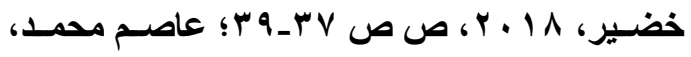
T 19

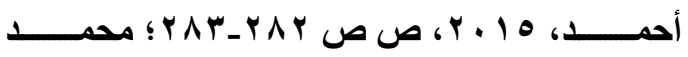

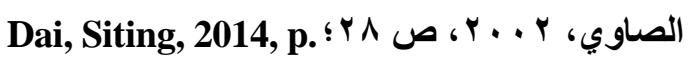
16; Matrix, \& Hodson, 2014, pp.17-27; Semetko, \& Scammell, 2012; Lester, 2006, ; ) ، ولأن الإنفوجرافيك هو وسيط تكنولوجي، لذلك فهو من الوسائط البصرية التي يجب أن يتمكن منها المتخصص في تكنولوجيا التعليم. يعد الإنفوجرافيك من الوسـائط المناسبة التي يمكن استخد/مها في التعلم النقال، لذلك يمكن تنمية مهارات إنتاج الإنفوجرافيك باستخدام التعلم النقال، حيث أثثتـت البحوث والاراسـات فاعلية استخدامه

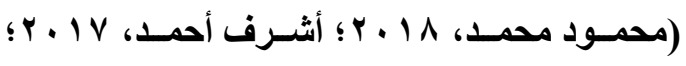

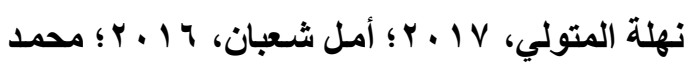

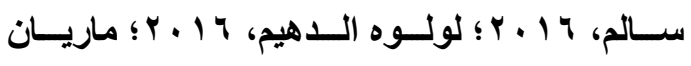

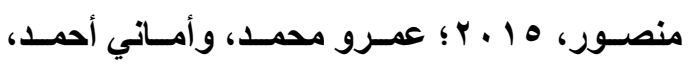

Salas Rueda, 2015; Kos, \& $\leqslant$. 10

.(Sims, 2014
الباحثـان أنسه يمكن من خـلال تحقيق معرفة أعمق للمحتـوى ومستويات أعلى لتنميـة مهارات إنتـاج الإنفوجر افيك الثابت بإستخدام برنـامج الفوتوشوب و التفكير الابتكـاري للدى الطـلاب، وذلكـ مـن خـلال التفاعل والمشـاركات التي يقومـوا بها مـع بعضهـم

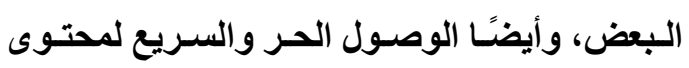
الاراسة في أي وقت وأي مكان. يقصد بالإنفوجر افيك بأنه تمثيل مرئي للبيانـات والمعلومات والمفاهيم المعقده لتقليل النصوص عن طريـق الجمـع بين أقل عدد مـن الكلمـات والصـور

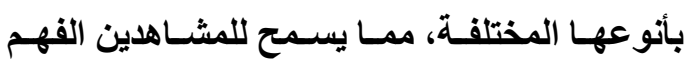
بسـرعة للأفكـار الأساسـية المـراد توصـيلها لهـــ خמ (Salas Rueda, 2015, p. 38) ، ويتميز بعدة

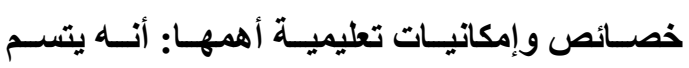
بالقدرة على ترميز المعلومـات، ويتســ بالتصـيم

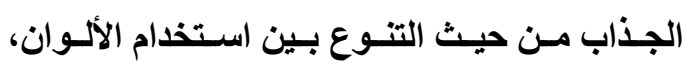
والصور، والرسومات، والخطوط، وهذا يسهم في قـــرة الإنفوجرافيـــ في مخاطبـة جميـع الأعمـار

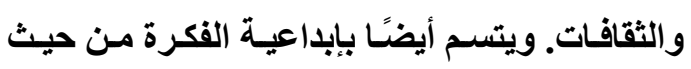
تقديمه المحتوى بثكل إبداعي، ويتسم بقدرته على ولى تنظـيم الأفكـار بطريقـة مفيــة، وإظهــار العلاقــات المعقدة بطريقة مرئية، ومقارنـة المعلومـات بطريقة

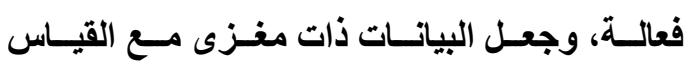

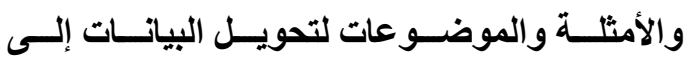
معلومات، يستخدم لشرح أي معلومـة في أي مجـال تعليمي، ويعد أداة مثالية لتوضيح شكل الأثياء غير

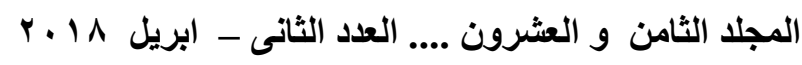


الجمعية المصرية لتكنولوجيا التعليم

الدهثة، الغرابة، الأسئلة، التظليل، التكرار، الحجم، شفرة اللون، التمثيل، والغموض (الثحات عتمـان،

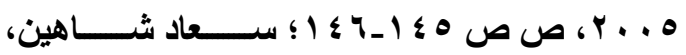

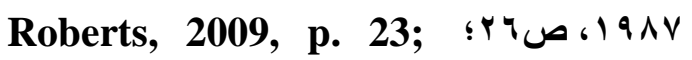
Brashears, Akers, \& Smith, 2005, p. 8; Dwrey, 1978, pp. 158-160)، وقد أجريت عدة بحوث ودراسات حول أنماط التلميحات؛ كما هو Liu, Lin, الحسال في دراسـة ليو، لين، وبـاس and Paas (2013) بالأسهم والخطوط من خلال بيئة التعلم النقال حيث ســاهمت علـى خفض الحمـل المعرفـي، و زيــادة التحصيل الدراسي وتنميـة المهارات العملية بثكل جيد ورفع الكفـاعة الذاتيـة للدى المتعلمين؛ ودراسـة Lin, Kuo, لين، كو، لين، لين، تثـانغ، وليو Lin, Lin, Chang, and Liu (2012) استخدمت التلميحات اللونيـة في التعلم النقال على مسـاعدة الطلاب على تذكر واسترجاع المطلومـات الخاصة بموضوع العلم، وتوصلت النتائج أيضًا إلى أن التلميحسات اللونيـة سـاهمت على تقــدم الطـلاب بثــكل متســاوي فـي التحصـيل والأداء المهــاري وخفض الحمـل المعرفـي وسـرعة الفهـم؛ ودراســة فونج (2008) Voong التي استخدامت التلميحات الإشـارية في التـعلم بالوسـائط المتعددة اللاسـلكية على تركيز إنتباه الطلاب نحو عملية تعلمهم وعدم تثـتيتهم مـن خـلال المثيـرات المختلفـة الموجـوده بالسـياق التعليمس؛ ودراسـة أولاسـفيرتنا، رينـود،
نظرًا لأن التعلم النقال يشتمل على العليد

مـن المشتتـات بإعطائـهـ الحريـة للمتعلمين بـالتجول الحر داخل البيئة التعليمية في أي وقت وأي مكان، فمن الممكن أن تعمل هذه الحرية على عدم تركيزهم في التعلم وتثتيتهم، لذلك فهو يحتاج إلى استخدام التلميحات لتركيز الانتبـاه على المثيرات الأصلية. ويقصد بالتلميحات تلك المثيرات الثانوية التي تركز (De Koning, الانتبـاه على المثيرات الأصلية ‘Tabbers, Rikers, \& Paas, 2009, p.117) وقد أجريت دراسات وبحوث أثثتت فاعلية استخدام التلميحـات (صـــي حسـين، 0 ـ ب؟ محمـــ أبـو

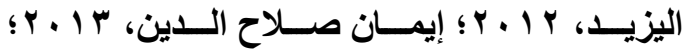

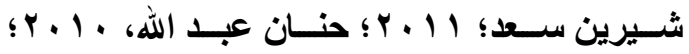
أسـامة هنـاوي، وصبري إبراهيم، ^ . . ץ؛ هثــام

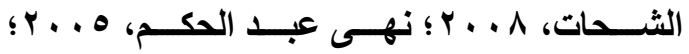
Yang, 2016; Boucheix, Lowe Putri, \& Groff, 2013; De Koning, Tabbers, Rikers, \&Paas, 2011; Lin, \& Atkinson, .(2011; Brashears, \& Lawver, 2005 توجد عدة أنمـاط للتلميحـات، من أهمها: التلمـيح المكتـوب، اللـونـي، الحركـة، الموســيقى، الأسـهم، الخطوط، ووضـع خطوط تعـ الكلمسات، الرسومات المتحركة، الوضع في دائرة، الوضع في إطسار، التـأثيرات البصـرية، التركيـب، المنظمـات المتقدمه، والتغير، الحداثة، الألفة، العرض المتعدد، التبـاين، التعقيــ، كثافـة المثيـر، التسـمية، عنصـر

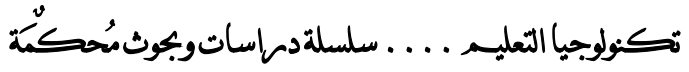


للنصـوص فقـ و التلميحـات السـمعية للنصـوص

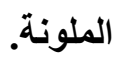

ويلاحظ أن هذه البحوث والدر اسـات لم تتنـاول

التلميحـات المكتوبة/اللونيـة أيهمـا الأنسب، ويقصد

بالتلميحـات المكتوبـة بأنها عبـارات نصية مـوجزة

تستخدم كطريقة بليلة لتوصيل المعلومـات المهمـة

و التركيـز عليهـا، وتسـتخدم فـي تنميـة عديـــــن

جوانب التـطم كزيــادة التحصيل الاراسـي، وإتقـان

المهارات، رفع القدرة على حل المشكلات، وخفض

الحمـل المعرفي لـدى المتعلمـين، وتحسـين إدراك وفهم المتعلم وانتقال أثر التعلم، وتقليل الوقت الذي يستغرقه المتطلم للبحث عن المعلومات الأساسية في المـواد التعليميـة. أمـا التلميحـات اللونيـة فهي أحـا أنمـاط التلميحـات البصـرية وتعرف بأنهـا مثيرات ثانوية باللون لتوجية انتباه وتركيز المتعلمين على المعلومـات المهمـة بموضوع التعلم، وتستخدم في لمي مسـاعدة المتعلمـين علـى دقـة الانتبـاه و اســخـام الرموز المناسبة للمعالجة والتخزين في الأكرة أي أنهـا تعمل على زيـادة احتفــاظ المتطلم بالمطلومـات، وخفض الحمل المعرفي، يستخدمها المتعلم بسهولية لاستعادة المطومسات من الذاكرة بعد فترات أطول، تقـوم بـــور الملخـص والموضــح فتوضــح النقــاط الغامضة وتظهر ها وتقوم بدور الملخص للموضوع

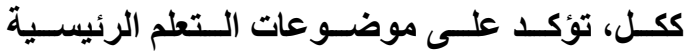
وتنظيمها، وجذب انتباة المتعلم. لذلك يركز البحث الحالي على هذين النمطين.
Oulasvirta, Renaud, رينتو، وسـولي Raento, and Sauli (2007) التلميحـات بالأســهم والخطـوط فـي بيـــات الـتعلم النقالة، فعملت على توفير فرص التفاعل الإجتمـاعي فيما بينهم ممـا يسـاعدهم على زيادة فرص تعلمهم بثكل موجهه دون تثتيت؛ ودراسة بيريث، مـارتن، أولريك كولد، ميكايل Berith, Martin, Ulrik Kold, and Mikael (2006) التلميحات من خلال تطبيقات التعلم النقال فسـاعدت على تكـوين علاقــات إجتماعيـة بـين الطـلاب مـع بعضهم البعض، وزيادة تثـاركهم في تنفيذ المهمـات المكلفين بها، ورفع دافعيتهم للإنجـاز والتحصيل

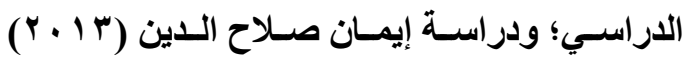
استخدمت التلميحات بالأسـهم والألوان عند تصميم

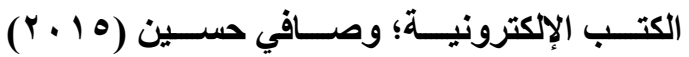

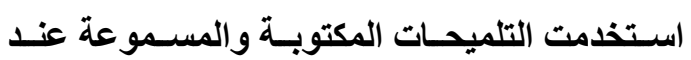
تصميم الألعاب الإكترزونيـة؛ ودر اسـة شيرين سـعد

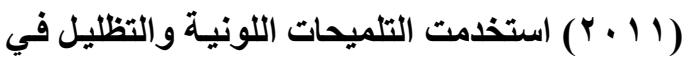
البيئــات الإلكترونيــة؛ ودراســـة حنــان عبــــ الله

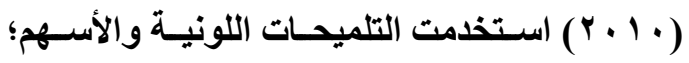

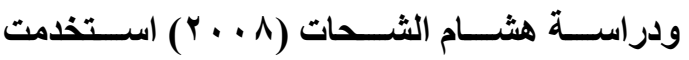
Kim, التلميحات المجسمة؛ ودراسـة كيم، جيلمسان \& Gilman (2008) المكتوبة مع الرسومات والتلميحات المسموعة مـع الرسومات في بيئة تعلم عبر الويب؛ ودراسـة نهى

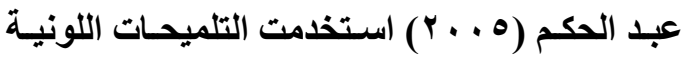

المجلد الثامن و العشرون .... العدد الثانى ـ ابريل 1 ـ r 
الجمعية المصرية لتكنولوجيا التعليم

ودراسـة محمـد البـاتع (ه . . ب)، ودراسـة كل مـن

Chen, شــين، مـــاجولاس، ديمـــاكوبلوس

‘Magoulas, \& Dimakopoulos (2005)

Kim, \& Allen ودراسـة كل من: كيم، وألين

Dean \& Yuliang ) ودين، ويوليانج

Terry \& Fathi (2002). ويذكر تري، فـاتي

(2004) أن الأسـلوب المعرفي الاستقلال/ الاعتمـاد

يـرتبط بطــرق معالجـة المعلومــات لـــى الأفـراد،

فالأفراد المعتمدين على المجال الإدراكي هم أفراد لا

يستطيعون تمييز الأثكال عن خلفيتها بعكس الأفراد

المسـتقلين عـن المجــال الإدراكـي، وعليـهـ فـإنهم

يختلفـون فـي أســاليبهم العقليـة مـن حيـث إدراك

المعلومة ومعالجتها، على عكس الأفراد المستقلين

الذين يتصفون بالذاتية في التعلم. وعلى ذلك تتمثل

العلاقـة بـين نمطي التلميحـات المكتوبـة واللونيـة

والأسـلزب المعرفي المستقل والمعتمـد في مراعـاة

الفـروق الفرديـة بـين المتعلمـين، بإعتبـار أن لكـل

متعلم أسلوب معرفي خاص يختلف به عن الآخرين.

وبالتــالي تظهـر أهميـة معرفـة الأســلوب المعرفـي

للمتعلم بما يُتيح وضعه في الأسلوب المناسب لتعلمه

على اعتبـار أنسه يوجــ مـتعلم يحتــاج عنـــ الـتعلم

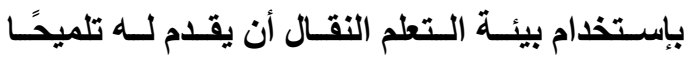

مكتوبًا، ومتتطم أخر يحتـاج تلميحًا لونيًا. وأوصت

بعض البحوث والدراسـات بضرورة دراسـة الأنمـاط

المختلفــة مـن التلميحسـات وعلاقاتهــا بالأســاليب

المعرفيـة للمتعلمـين، بمـا يضـمن تقديم التلميحـات
توجد علاقة بين أنماط التلميحات المكتوبـة

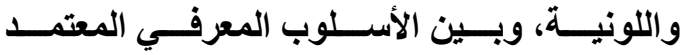

والمستقل، وذلك وفقًا لاختلاف خصـائص المتعلمين

و إمكانـاتهم وقدراتهم وأسـاليب تعلمهم، فيلاحظ أن

الأساليب المعرفية بمثابـة طرائق متميزة أو عادات

عامـة شـبه ثابتـة للتفكيـر و أســاس بنـائي لسـلوك

الأفراد، حيث أنها هي المسئولة عن الفروق الفردية

في كثير من العمليات النفسية والمتغيرات المعرفية والإدراكية والوجدانية، ما يجعلها تعبر عن الفروق الفرديـة الثابتـة نسـيبًا في طرائـق تكـوين وتنـاول وتنظيم المعلومـات والخبرات التي يمر بها الفرد. فتعـــ الأســاليب المعرفيــة مــن أهـــم مجموعــة الاسـتعدادات المختلفـة لـدى الفـرد، التــي تـؤثر في التعليم، فهي بمثابـة أسس يُعتمد عليها في دراسـة الفـروق بـين الأفـراد فـي أسـاليب تعـاملاتهم مــع المواقف الخارجية بمـا فيها من موضوعات سواء كانت هذه المواقف تربويـة أو مهنيـة أو اجتماعيـة

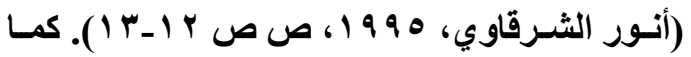
تختلف خصسائص المتعلمين في كل أسـلوب عن الآخر، وكذلك في كيفية استقبال المتعلم لتعلمه، وقد أثبتـت البحسوث و الار اسـات وجـود تـأثير لأسـاليب التتطم و التفاعل بينهـا وبـين المعالجـات التجريبيـة كالتلميحات والتذذية لراجعة واللاعم على مخرجات

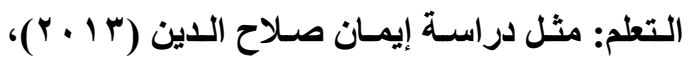

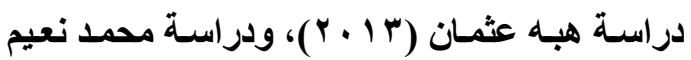

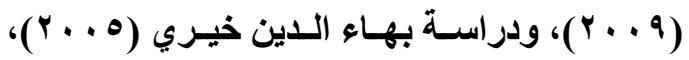

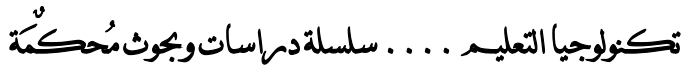


التعليمـي؛ تـرتبط التلميحسـات بعديـــــــن الأسـس والمبــادئ النظريــة المنبثقــة مـن نظريــات الـتعلم المختلفة؛ حيث تعتمد التلميحات على نظرية الترميز الثـائي وذلـك لأنها تؤكلد على أهميـة التزامن في استخدام النظام اللفظي والنظام الغير اللفظي في آن واحد عنـــ التعلم حيث أن ذلـك يـؤدي إلـي تيسير عملية التعلم ويزيد من سـهولة اكتسـاب واسترجاع

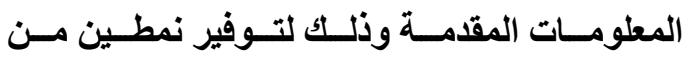
التمثيلات الذهنيـة اللفظيـة وغير اللفظيـة بـلَّا مـن

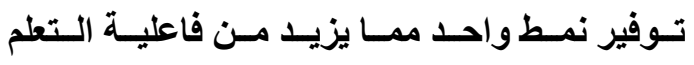
(Miller, 1956)، أيضَّا تعتمــ التلميحـات على نظرية معالجة المعلومات التي تري أن التعلم عملية معرفية توصف بأنها تغير في المعرفة المخزنـة في الـذاكرة، وأن الـذاكرة تلعب دورًا مهمًا في التعلم المعرفي، فالتعلم يحدث عندما يتم تخزين المعلومـات في الذاكرة بشكل منظم، كما تنظر هذه النظريـة إلي المتعلم كمعالج للمعلومات فالتعلم يحدث عندما تأتي المعلومــات مـن البيئة تُم يقـوم المـتعلم بمعالجتهـا ويخزنها في الذاكرة ثم تخرج كمخرجات في شكل قـــرات متعلمــة (عصــام الطيـب، ربيــع رشــوان،

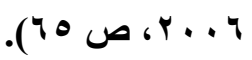
مشكلة البحث نبعت مشكلة البحث الحالي من عدة محاور هي: أولا: زيادة إقبال الطلاب على استخدام وسائط التعلم النقال في التعليم: وهذا ما أكدته دراسات عديدة
المناسبة لكل متعلم وفقًا لخصائصسه وقدراتـه العقلية

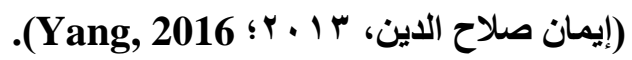
وعلى ذلك فالبحث الحالي يهدف إلى دراسـة أثر التفاعل بين نمط التلميحات (المكتوبة/اللونيـة) والأسلوب المعرفي (الأعتماد على المجال/الأستقلال عن المجـال) في التعلم النقـال على تنميـة مهارات إنتـاج الإنفوجرافيك باستخدام برنـامج الفوتوشـوب والتفكير الابتكـاري لـدى طـلاب تكنولوجيـا التعليم بالقرقة الثانية بمقرر إنتاج الرسوم التعليمية. يسـتند البحــث الحسالي على مجموعـة مـن النظريـات والمبادئ منها النظريـة البنائية التي تعد النظريـة الرئيسية للتعلم الآن، فهي الأكثر مناسبة

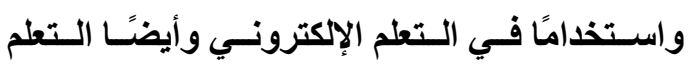
النقال، فتتدرج تحتها كثير من النظريات مثل نظريـة التعلم الموقفي أو المعرفة الموقفية، وهذا مـا يعتمد علية التعلم النقال من خلال توجيه معرفة الأفراد في

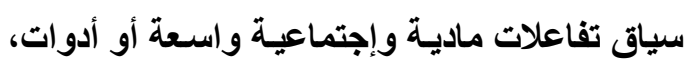
ومعاني منشأة ثقافيًا، ويناء المعاني من خلال نشـاط اجتمـاعي؛ ونظريـة النشـاط التـي تركز على نظــام النشاط الذي يقوم به المتعلم بإستخدام أدوات معينة،

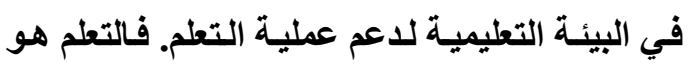
عملية بناء الحدث من خلال العمل وليس من خلال التلقي السلبي للمعرفة (محمد عطية، ه 1 ـ Y، ص صن

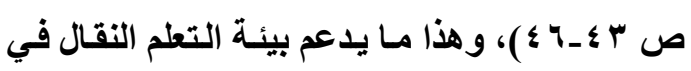
البحث الحسالي حيث يكلف الطـلاب بمجموعـة مـن المهــات والتكليفـات الخاصـة بإنتـاج الإنفوجر افيك 
الجمعية المصرية لتكنولوجيا التعليم

فاعلية التلميحات اللونية في التعلم النقال في تنمية التحصيل والأداء المهاري وخفض الحمل المعرفي وسرعة الفهم؛ ودراسة أولاسفيرتا، رينود، رينتو، Oulasvirta, Renaud, Raento, وسولي \&Sauli (2007) أهمية تقديم التلميحات من خلال بيئات التعلم النقالة في تنمية فرص التفاعل الإجتماعي بين المتعلمين ويعضهم البعض؛ ودراسة بيريث، مارتن، أولريك Sولد، ميكايل يل

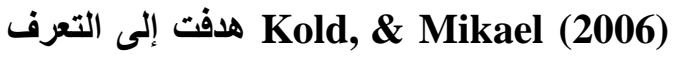
على فاعلية تقديم التلميحات من خلال تطبيقات التعلم النقال في تنمية تكوين علاقات إجتماعية بين الطلاب وتوجيههم نحو عملية التعلم؛ بناءًا على ماسبق يتضح أن هذه الاراسات لم تستخلم متغيرات البحث الحالي؛ لذلك هناك حاجة للتعرف على أنسب نمط عند تقديم التلميحات المكتوبة أم اللونية في

$$
\text { بيئة التعلم النقال. }
$$

ثالثا: تضارب الاراسات والبحوث التي ألقت الضوء على تقليم التلميحات وتفاعلها مع الأسلوب المعرفي سواء في التعلم النقال أو بيئات أخري: بالرغم من إثـارة الاراسات والبحوث السابقة التي تم ذكر ها في مقدمة البحث إلى أهمية التلميحات في العملية التعليمية وخصوصًا في بيئات التعلم المعتمدة على الويب في تنمية عديد من نواتج التعلم المختلفة، إلا أنه يوجد تضارب بين نتائج هذه الدراسات حول استخدام أنماط التلميحات. أيضًا
Iglesias, كدراسة إجليسياس، جارسيا، وسانشيز ،arcía, and Sánchez (2017) ماتيسكو، جروبيل Pimmer, Mateescu, and Gröhbiel (2016) ودراسة هاني شفيق

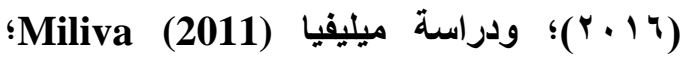
Chang, Wong, ودراسة تثانج، ونج، وشانج \& Chang (2011) وحنان عبدالسلام (11 +ץ)؛ ودراسة تثين، وانج وهوانج (2008) (Chen, Wang, \& Huang) دراسة شيه (2007) Shih وكثيرًا من البحوث والاراسات على هذا المنوال، وهذا ما يؤكد على أهمية استخدام التعلم النقال في البحث الحالي. ثانيا: استخدام تلميحات أخرى مع بيئة التعلم النقال، وعدم استخدام تلميحات البحث الحالي: فبالرغم من ارتباط بيئة التعلم النقال عمومًا ببناء المعارف وتثثاركها وبالمهمات التعليمية وهذه المهمات لكي يتم إنجازها فهي تمر بمجموعة من المراحل منها وأهمها التلميحات المقدمة للمتعلمين لتحسين نواتج تعلمهم واستخدمت كثيرًا من التلميحات مع هذه Liu, Lin, البيئة فقد استخدمت ليو، لين، وباس ( \& Paas (2013) التلميحات الأنسب الأسهم أم الخطوط من خلال بيئة التعلم النقال على خفض الحمل المعرفي لاى المتعلمين؛ ودراسة لين، كو، لين، لين، تثانغ، وليو \&in, Kuo, Lin, Lin, Chang, \& Liu (2012)

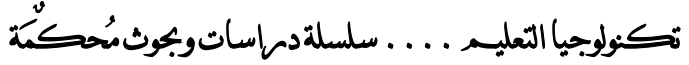


كل منتج من قبل كل طالب تكون مختلفة عن الطالب الآخر لكون الإنفوجرافيك متميز بالناحية الابتكارية والإبداعية أيًا ما كان نوعه، كما وجد أن الطلاب في حاجة لروية أعمال زملائهم للإستفادة منها وتوجيههم أيضًا، وكان من أفضل مصادر التوجيه من خلال تقديم التلميحات لهم بصفه مستمرة وفقًا لمنتجاتهم وذلك من خلال بيئة التعلم النقال. وللتأكد من ذلك أجريا دراسة استكثافية بهدف التعرف على الحاجات التي يحتاجها الطلاب والمشكلات التي قابلتهم أثثاء عملية الإتتاج وتعديل المنتج لجطه مطابق لمعايير التصميم التطليمي لنوع المنتج، و التعرف على مدى قدرتهم على استخدام بيئة التعلم النقال، وذلك من خلال إعداد استبيان" وتوزيعه على الطلاب وقسم الباحثان هذه الحاجات إلى جزئين: الأول حاجات خاصة باحتياجات الطالب لمعارف ومهارات إنتاج الإنفوجرافيك الثابت التعليمي بإستخدام برنامج الفوتوشوب وكان عدد العبارات ثمان عبارات بثمان مهمات أساسية لانتاج الإنفوجرافيك، بالإضافة إلى سؤال مفتوح للطلاب لتحديد مهارات ومعارف أخرى يريدونها، أما الجزء الثاني فكان مختص ببيئة التعلم النقال وتطبيقات الويب وتكون هذا الجزء من عشر عبارات الإجابة الخاصة بها نعم أو لا، وقد طبقت هذه الاراسة على عدد • r طالبًا وطالبة من طلاب الفرقة الثانية تكنولوجيا التعليم، وتم تحليل النتائج للتوصل إلى

( الاستبيان مرفق بملحق () *
توصية بعض الدراسات والبحوث بإستخدام أنواع أخرى من التلميحات لأهميتها في العملية التعليمية ومحاولة استكثاف ملامحها ومعاييرها وكيفية توظيفها في بيئات التعلم الإكترونية المختلفة، وكما تم ذكره في مقدمة البحث أنه توجد بعض الدراسات والبحوث بوجود تفاعل بين التلميحات (المكتوبة/ اللونية) والأسلوب المعرفي (المستقل/ المعتمد) في بيئات التعلم الأخرى غير البيئة المستخدمة في البحث الحالي، وهذا ما دعى الباحثان الكثف عن أثر التفاعل بينهما في بيئة التعلم النقال لتنمية مهارات إنتاج الإنفوجرافيك التعليمي والتفكير

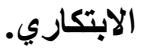

رابعا: ألقت الدراسات السابقة على علاقة كل متغير مستقل على حدة بمتغيرات البحث الحالي (التحصيل المعرفي، الأداء المهاري، والتفكير الابتكاري) لكنها لم تتناول معارف ومهارات إنتاج الإنفوجرافيك التعليمي التي تم تحديدها في البحث الحالي، وقد تم ذكر هذه الاراسات في مقدمة البحث. خامسًا: توجد حاجة لدى طلاب تكنولوجيا التعليم إلى استخدام التعلم النقال في تنمية مهارات إنتاج الإنفوجرافيك الثابت التعليمي بإستخدام برنامج الفوتوشوب، حيث وجد الباحثان ضعف لاى الطلاب عند إنتاجهم الإنفوجرافيك بمقرر إنتاج الرسوم التعليمية بالفرقة الثانية تكنولوجيا التعليم، واحتياجهم المستمر إلى التوجيه وتركيز إنتباههم نحو الهذف المطلوب تحقيقه، ولأن خطوات إنتاج

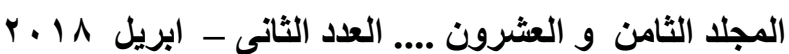


الجمعية المصرية لتكنولوجيا التعليم

الدراسات سابقة الذكر، ولكن الاراسات التي أشارت إلى تقديم التلميحات في بيئات التعلم الإكترونية المختلفة لم تحدد أي من شكل التلميحات هو الأنسب وكيف تقدم وما الاستراتيجية المناسبة من أجل تنمية المهارات المختلفة سواء مهارات إنتاج الإنفوجرافيك أو تنمية التفكير الابتكاري، وأيضًا لم تتوصل الاراسات سابقة الأكر مدى علاقة التلميحات في التعلم النقال بالأساليب المعرفية المختلفة. من هنا ظهرت مشكثة البحث الحالي والتي يمكن صياغتها في العبارة الآتية": وجود حاجة إلى دراسة أثر التفاعل بين التلميحات (المكتوبة /اللونية) والأسلوب المعرفي (المعتمد /المستقل) في رلي التعلم النقال مصمم حسب معايير تكنولوجية سليمة على تنمية التحصيل المعرفي ومهارات إنتاج الإنفوجرافيك الثابت باستخدام برنامج الفوتوشوب والتفكير الابتكاري بمقرر إنتاج الرسوم التعليمية لاى طلاب تكنولوجيا التعليم، وهو مالم تتناوله البحوث والاراسات السابقة، التي اقتصرت على دراسة كل متغير على حدة، دون تحديد العلاقة بين

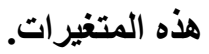

\section{أسئلة البحث}

على ضوء ذلك يمكن صياغة السؤال الرئيس

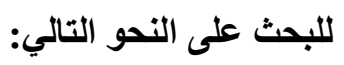

أهم المعارف والمهارات التي يحتاجها الطلاب إنتاجهم الإنفوجرافيك الثابت بإستخدام برنامج الفوتوشوب، ومدى قدرتهم على التعامل مع بيئة التعلم النقال وتطبيقات الويب بصفه عامة؛ وأظهرت النتائج إلى أن الطلاب يفتقدوا أكثر من ••\% من المهارات الرئيسة لإتتاج إنفوجرافيك تعليمي ناجح، وأجمع 09 \% منهم على أنهم يحتاجون من المعلم بشكل مستمر إلى عمليات توجيه مستمرة عند تنفيذ التكليفات الخاصة بهم، ولكي يستطيعوا تعديلها، ونسبة .0 \% منهم يريدون أن يروا منتجات زملائهم ليستفيدوا من التلميحات المقدة لهم، ونسبة ، 9 \% أرادوا أن يتواصلوا مع المعلم بصفه مستمرة لمتابعة أعمالهم وتقديم التلميحات لهم لكي يستطيعوا تحسين تعلمهم وأداءهم، وأشار حوالي ه9 \% إلى أنهم يريدوا أن يعرفوا الخطوات التي توصل بها زملائهم إلى المنتج النهائي لأن كل منتج له خطواته التي تختلف عن خطوات إنتاج المنتج الرئيس، ونسبة . . 1\% من الطلاب لايهم قدرات عالية عند استخد/مهم تطبيقات الويب المختلفة ويمتلكون أجهزة نقالة وأيضًا لديهم استعداد على استخدام بيئة التعلم النقال عند الدراسة. من نتائج الاراسة الاستكثافية السابقة يمكن القول أن بيئة التعلم النقال كمستحدث تكنولوجي يتميز بخصائص تميزه عن غيره يمكن

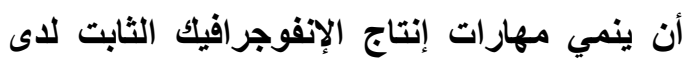
المتعلمين، ويقدم من خلاله التلميحات كما أشـارت

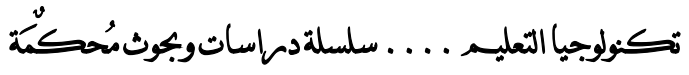


لمهــــارات إنتـــاج الإنفوجر افيــــ الثابــــ باسـتخدام برنـامج الفوتوشـوب، والتفكير الابتكاري) بمقرر إنتاج الرسوم التعليمية لــدى طـلاب الفرقــة الثانيــة تخصــص

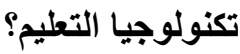

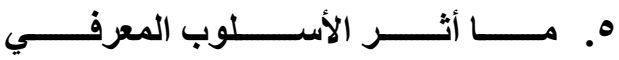
(المعتمد/المستقل) في بيئة التعلم النقـال على تنميـة كل مـن: (الجوانب المعرفيـة،

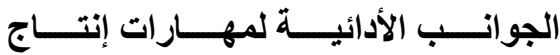
الإنفوجر افيـك الثابــت باســتخدام برنــامج الفوتوشـوب، والتفكير الابتكـاري) بمقرر إنتاج الرسوم التعليمية للى طلاب الفرقة الثانية تخصص تكنولوجيا التعليم؟ 7. مـــا أثـر التفاعـل بـين نمـط التلميحـات (المكتوبة/اللونيــة) والأســلوب المعرفـي (المعتمد/المستقل) ببيئة التعلم النقال على تنميـة كـلـ مـن (الجوانـب المعرفيـة، الجوانـــب الأدائيـــة لمهــــارات إنتـــــاج الإنفوجرافيـك الثابــت باســتخدام برنسامج الفوتوشـوب، والتفكير الابتكاري) بمقرر إنتاج الرسوم التعليميـة للى طلاب الفرقة الثانية تخصص تكنولوجيا التعليم؟

\section{أهداف البحث} يهدف البحث الحالي التوصل إلى:
كيف يمكن تصميم التعلم النقال باستخدام نمطين من التلميحات (المكتوبة / اللونية) ودراسة أثر تفاعلهما مع الأسلوب المعرفي (المعتمد /المستقل) في التعلم النقال على تنمية مهارات إنتاج الإنفوجرافيك والتفكير الابتكاري للى طلاب تكنولوجيا التعليج؟ كما أمكن تحليل هذا السؤال إلى

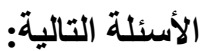

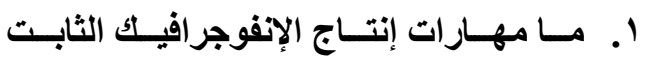
باستخلام برنـامج الفوتوشوب بمقرر إنتاج الرسوم التطليميـة لدى طلاب الفرقة الثانيـة تخصص تكنولوجيا التعليج؟ Y. مـا معايير تصـميم بيــة التعلم النقـال في ضـو نمسط التلميحـات (المكتوبة/اللونيـة) والأسلوب المعرفي (المعتمد/المستقل)؟ r. ما التصميم التعليمي لبيئة التعلم النقال في ضـو نمـط التلميحـات (المكتوبة/اللونيـة) والأســلوب المعرفـي (المعتمد/المسـتقل) لتنمية مهارات إنتاج الإنفوجرافيك الثابت باسـتخدام برنسامج الفوتوشـوب والتفكير الابتكـاري بمقرر إنتـاج الرسـوم التعليميـة لـــى طـلاب الفرقــة الثانيــة تخصــص

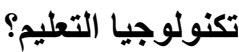
؛. مـا أثثر نمط التلميحات (المكتوبة/اللونيـة) في بيئة التتلم النقـال على تنميـة كل من: (الجوانـب المعرفيـة، الجوانـب الأدائيـة 
الجمعية المصرية لتكنولوجيا التعليم

ا ـ التأكيـد علـى تفعيـل أنمــاط التلميحـات عنـــ

$$
\text { تصميم بيئات التعلم النقال. }
$$

r. توجيـه إهتمـام القـائمين على تصـميم التتعلم

النقال إلى ضرورة توفير أنمـاط مختلفة من

التلميحـات وفقَـا للأسـلوب المعرفي لمواجهـة

الفروق الفردية بين المتعلمين.

r. يعتبر تطبيقَا لأبحـاث التفاعل بـين المعالجـة

والإستعداد، والتي تـوائم بيلن طريقـة التعلم

$$
\text { والفروق الفردية بين المتعلمين. }
$$

؛. إثراء المجـال البحثي لتخصص تكنولوجيـا

التعليم للتركيز على توظيف التلميحـات في

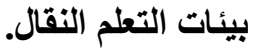

هـ يعد البحث الحالي مواكبًا للاتجاهـات التربويـة

الحلثة التي تؤكد على جعل المتعلم محور

العملية التعليمة منتج للمعرفة وليس متلقي

$$
\text { وتغيير دور المعلم كمرشدًا. }
$$

هدود البمث

$$
\text { يقتصر البحث الحالي على: }
$$

1- مقـرر إنتــاج الرسـوم التعليميـة (إنتـــاج

الإنفوجرافيـك الثابـت التعليمسي بإســتذام

برنامج (الفوتوشوب) لطلاب الفرقة الثانية

تكنولوجيـا التعليم بكليـة التربيـة النوعيـة

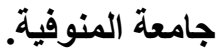

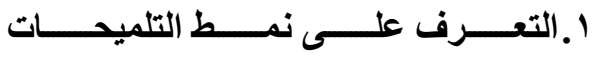

(المكتوبة/اللونية) الأنسب في بيئة التعلم

النقـال على تنميـة كـل مـن: (الجوانـب

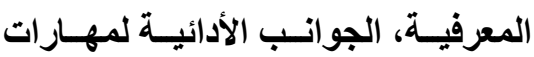

إنتــاج الإنفوجرافيـــ الثابـت باســتخدام

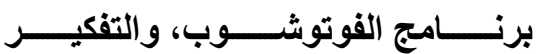

الابتكاري) بمقرر إنتاج الرسوم التعليمية

لــدى طـلاب الفرقـة الثانيـة تخصـص

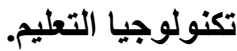

ץ.الكثـف عـن أثــر التفاعـل بـين نمــط

التلميحات (المكتوبة/اللونيـة) والأسلوب

المعرفي (المعتمد/المستقل) بيئسة التعلم

النقــال على تنميـة كـل مـن: (الجوانـب

المعرفيـة، الجوانـب الأدائيـة لمهـــارات

إنتــاج الإنفوجرافيـــ الثابــت باسـتخدام

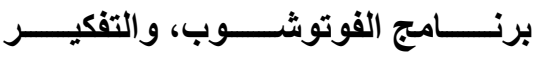

الابتكاري) بمقرر إنتاج الرسوم التعليمية

لـــى طـلاب الفرقـة الثانيـة تخصـص

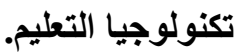

r.علاج قصور طلاب تكنولوجيا التعليم عند

إنتــاج الإنفوجر افيـك الثابـت باســتخدام

برنــامج الفوتوشـوب وتنميـة التفكيـر

الابتكاري لاديهم.

أهميهة البمث

قد يفيل البحث الحالي فيما يلي : 
أـ المتغيرات المستقلة: يشتمل البحث الحالي

على متغيرين مستقلين وهما نمط التلميحات (المكتوبة/ اللونية)، والأسلوب المعرفي (الاعتماد/ الاستقلال) في بيئة التعلم النقال.

ب- المتغيرات التابعة: يشتمل البحث الحالي على المتغيرات التابعة وهي (الجوانب المعرفية، الجوانب الأدائية لمهارات إنتاج الإنفوجرافيك ببرنامج الفوتوشوب، والتفكير الابتكاري).

\section{عينة البحث}

قام الباحثان باختيار عينة البحث بطريقة مقصودة من طلاب الفرقة الثالثة تكنولوجيا التعليم بكلية التربية النوعية جامعة المنوفية وتكونت العينة من وه طالب وطالبة وتم تقسيمهم إلي أربع مجموعات، فتكونت المجموعة الأولى من r ا طالب وطالبة، المجموعة الثانية من V Vالب وطالبة، المجموعة الثالثة ا 1 طالب وطالبة، والمجموعة الرابعة 9 1 طالب وطالبة. وعلى ضوء المتغيرات المستقلة للبحث تم استخدام التصميم التجريبي وهو التصميم العاملى البسيط (YXY) الأي يهتم بقياس أثر متغيرين مستقلين، ولكل متغير مستويين في نفس الوقت (محمد عطية، سا ب. (Y، ص \& \&). ويوضح شكل (1) التصميم التجريبي للبحث.

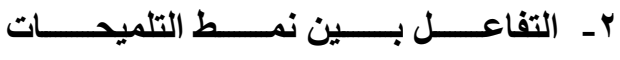

(المكتوبة/اللونيـة)، والأســلوب المعرفي

(الاعتمــاد علــى المجال/الاســتقلال عـن

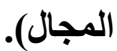

هـ

نظرًا لأن البحث الحالي يعد من فئة البحوث

التطويرية في تكنولوجيا التعليم، لألك فقد استخدم كلً من المنهج الوصفي التحليلي، ومنهج تظوير المنظومات التعليمية، والمنهج التجريبي. حيث استخدم المنهج الوصفي التحليلي إعداد قائمة المهارات الخاصة بإنتاج الإنفوجرافيك ببرنامج الفوتوشوب، ودراسة التلميحات والأسلوب المعرفي ببيئات التعلم النقال. واستخدم منهج تطوير المنظومات التعليمية في تصميم وتطوير بيئة التعلم النقال وفَّا لتمطي التلميحات. واستخدام المنهج التجريبي للوقوف على أثر المتغير المستقل وهو التفاعل بين نمط التلميحات والأسلوب المعرفي في التعلم النقال على المتغيرات التابعة وهي التحصيل والجاتب الأدائي لإنتاج الإنفوجرافيك التعليمي والتفكير الابتكاري لاى طلاب تكنولوجيا التعليم. هتغيرات البحث يتضمن البحث الحالي المتغيرات التالية: 
الجمعية المصرية لتكنولوجيا التعليم

\begin{tabular}{|c|c|c|c|c|}
\hline التطبيق البعدي للأدوات & اللونية & المكتوبة & مط التلميحات & التطبيق القبلي \\
\hline \multirow{2}{*}{ 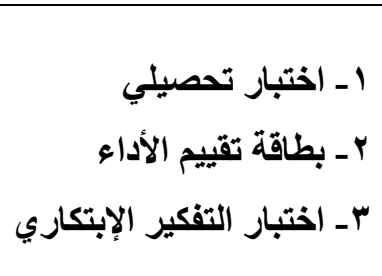 } & 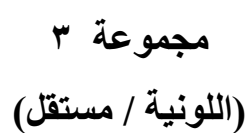 & (المكتوبة/ مستقل) & المستقل & \multirow{2}{*}{ ا ــ إختبار تحصيلي } \\
\hline & (اللونية/ معتمدة) & (المكتوبة/ معتمدة) & المعتمد & \\
\hline
\end{tabular}

$$
\text { شكل (1) التصميم التجريبي للبحث }
$$

للتطبيق البعدي يرجع إلى أثر اختلاف نمط

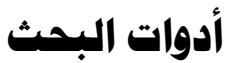

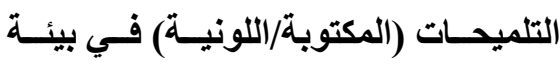

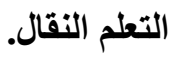

r. لا يوجد فرق ذو دلالة إحصائية بين متوسطي

درجـات طلاب المجموعتين التجريبيتين في اختبـار التحصيل الاراسـي للتطبيق البعدي يرجـع إلـى أثـر اخـتلاف الأســلوب المعرفي (الاستقلال/الإعتماد) في بيئة التعلم النقال. r. توجــــــروق ذات دلالــة إحصــائية بــين متوســطات درجــات طــلاب المجموعــات التجريبيــة الأربــع فــي اختبــار التحصـيل الاراسـي للتطبيـق البعـدي ترجـع إلـى أثـر

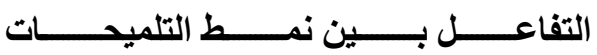
(المكتوبة/اللونيـــة) والأســلـوب المعرفــي (الاستقلال/الإعتماد) في بيئة التعلم النقال. ؛. لا يوجـــ فــرق ذو دلالــة إحصــائية بـين متوســطي درجــات طـــلاب المجمــوعتين التجريبيتين في بطاقة تقيـيم الأداء للتطبيتق
1.اختبــار تحصــيلي للجوانــب المعرفيــة

لمهـارات إنتـاج الإنفوجرافيك باسـتخدام برنامج القوتوشوب. Y.بطاقــــة تقيـــيم أداء مهـــــارات إنتـــــاج

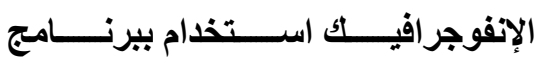
الفوتوشوب لقياس الجانب الأدائي. ץ.اختبـار التفكير الابتكاري لمهارات إنتـاج

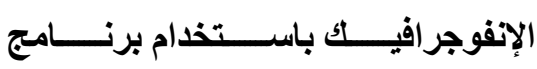

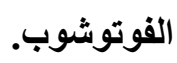

ع.اختبار الأشكال المتضمنة Embedded

Figure Test وريسـكن ترجمـة أنــور الثــرقاوي، سليمان الخضري.

\section{فروض البمث}

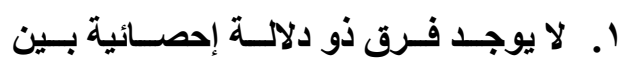

متوســـي درجـات طــلاب المجمــوعتين

التجريبيتين في اختبار التحصيل الاراسي

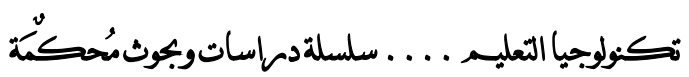


التجريبية الأربع في اختبار التفكير الابتكاري

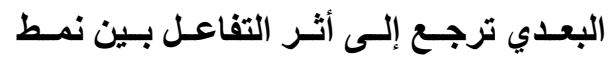

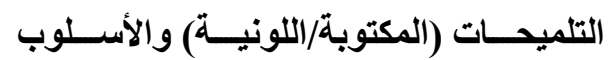

المعرفي (الاستقلال/الإعتماد) في بيئة التعلم

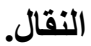

\section{هلفص خطوات البمث}

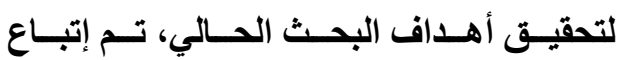

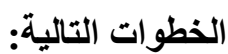

ا ـ إعداد الإطار النظري للبحث من حيث دراسـة

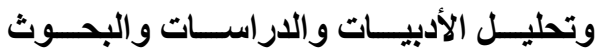

السابقة المرتبطة بمتغيرات البحث.

r. إعـداد قائمــة بالمعـيير التصـميمية الخاصـة

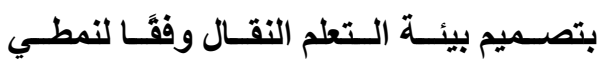

التلميحات المكتوبة واللونية.

r. التصــميم التعليمــي لبيـــة الــتعلم النقـــال

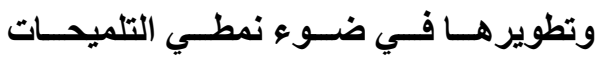

المكتوبــة واللونيـة لطـلاب الفرقــة الثانيـة

تخصـص تكنولوجيـا التعلـيم بمقـرر إنتـاج

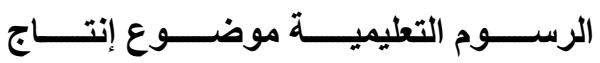

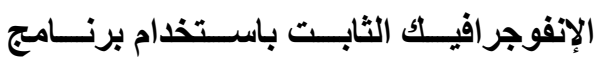

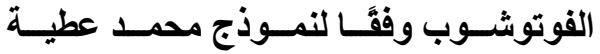

$$
.(Y \cdot V)
$$

ع. بنــاء أدوات البحـث والمتمثـــة فــي اختبـار

تحصيلي، وبطاقة تقييم أداء مهارات، وبطاقة

$$
\text { تقييم أداء مهارات. }
$$

البعدي يرجع إلى أثر اختلاف نمط التلميحات (المكتوبة/اللونية) في بيئة التعلم النقال.

๑. لا يوجد فرق ذو دلالة إحصائية بين متوسطي

درجـات طلاب المجمو عتين التجريبيتين في

بطاقة تقييم الأداء للتطبيق البعدي يرجع إلى

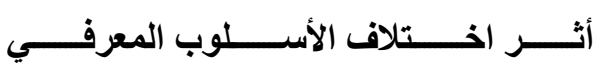

(الاستقلال/الإعتماد) في بيئة التعلم النقال.

7. توجـــــروق ذات دلالــة إحصــائية بـين

متوســطات درجــات طــلاب المجموعـــات التجريبيــة الأربــع فـي بطاقـة تقيـيم الأداء

للتطبيق البعدي ترجع إلى أثر التفاعل بين

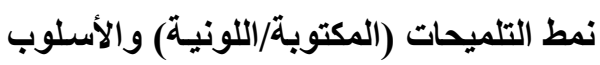
المعرفي (الاستقلال/الإعتماد) في بيئة التعلم

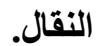

V. لا يوجد فرق ذو دلالة إحصائية بين متوسطي

درجـات طلاب المجموعتين التجريبيتين في

اختبـار التقكيـر الابتكـاري للتطبيـق البعـدي

يرجـع إلـى أثــر اخـتـلاف نمــط التلميحـات (المكتوبة/اللونية) في بيئة التعلم النقال.

^. لا يوجد فرق ذو دلالة إحصائية بين متوسطي

درجـات طلاب المجمو عتين التجريبيتين في

اختبـار التفكيـر الابتكـاري للتطبيـق البعـدي

يرجـع إلـى أثـر اخـتلاف الأسـلوب المعرفي الابني

(الاستقلال/الإعتماد) في بيئة التعلم النقال.

9. توجـــــــروق ذات دلالـــة إحصــائية بــين

متوســطات درجــات طــلاب المجموعـــات

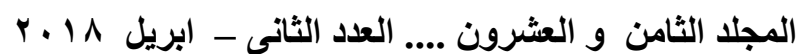


- التعلم النقال: تبنى الباحثان تعريف محمد

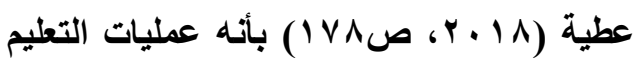
والتفاعل وتوصيل المحتوى التي تحدث خارج الجدران، أثناء تنقل المتعلمين في سيقات بيئية موقفية متعددة في أي مكان ووقت، بإستخدام الأجهزة الإكترونية النقالة، مثل المساعد الرقمي الثخصي، والكمبيوتر الكفي، والمحمول، والتليفونات الأكية، والتليفونات الخلوية، وأي أجهزة إلكترونية محمولة أخرى. ـ الأسلوب المعرفي: تبنى الباحثان تعريف أنور

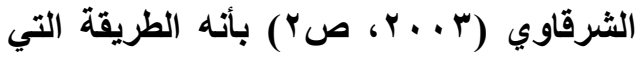
يتميز بها الفرد أثناء معالجته للموضوعات المختلفة التي يتعرض لها في مواقف الحياة اليومية مما يجعله خاصية لثخصية تظهر في نماذج سلوكه الإدراكية والعقلية. - الإنفوجرافيك: يعرف إجرائيًا بأنه تحويل المواقف التعليمية التي تحتوي على كم كبير من النصوص إلى أثكال مرئية معتمدًا في ذلك على الصور والرسومات والأيقونات، لتسهل على المتعلم فهمها بطريقة أيسر وأسرع وقت ممكن، وأقتصر البحث الحالي على الإنفوجرافيك الثابت المنتج بواسطة برنامج الفوتوشوب. ـ التفكير الابتكاري: تبني الباحثان تعريف سيد خير الله وهو قدرة الفرد على الإنتاج إنتاجًا يتميز بأكبر قدر من الطلاقة والمرونة والتلقائية والأصالة، وبالتداعيات البعيدة كاستجابة
•.إجراء التجربـة الاستطلاعية لضـبط أدوات البحث وإجراء التعديلات اللازمة.

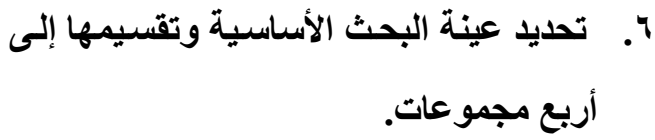

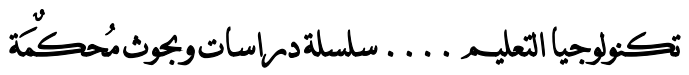


Trakler (2007, p.1) التعلم الذي يتم بإستخدام الأجهزة المحمولة الصغيرة، كالحاسبات الثخصية المحمولة، والهواتف الذكية، والمساعدات الرقمية الثخصية، والأجزة المحمولة باليد. وعرفه معه روجرز Rogers (2011, p.4) وقت وأي مكان بإستخدام الأجهزة اللاسلكية الصغيرة والمحمولة يدويًا مثل الهواتف المتنقلة، والمساعدات الرقمية الثخصية، والحاسبات اللوحية الثخصية، وغير ذلتك من الأجهزة Caudill (2007, p.2) المحمولة. ويعرفه كاوديل أن التعلم النقال أداة فريدة وجديدة للتعلم من بعد، وهو أي تطبيق من تطبيقات التعلم الإكتروني يتم على الأجهزة الرقمية النقالة. ويتفق كل من زينب

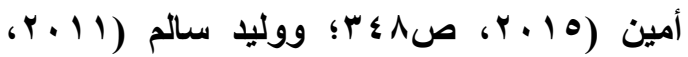
صبه 1) أن التعلم النقال هو ذلك النوع من من التعلم الذي يمكن أن يحدث نتيجة الاعتماد على بعض الأدوات الرقمية التي يمكن حملها باليد والتي من خلالها يتم الاطلاع عللى محتويات التعلم المتنوعة دون أي اعتبارات زمانية أو مكانية.

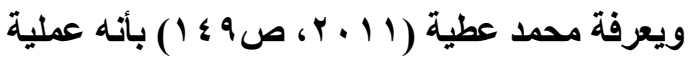
توصيل المحتوى الإكتروني، ودعم المتعلم، وإدارة عملية التعلم والتفاعلات التعليمية عن بعد، في أي وقت ومكان، بإستخدام أجزةة رقمية محمولة، وتكنولوجيات الاتصال اللاسلكي. كما يعرفة محمد

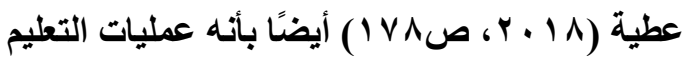

لمشكلة أو موقف أو مثير (سيد خير

$$
\begin{aligned}
& \text { الله، 19191 1، صن). } \\
& \text { الإطار النظري لابحث }
\end{aligned}
$$

التلميحات وعلاقتها بالأسلوب المعرفي في

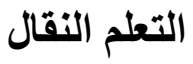

استهدف الباحثان من إعداد الإطار النظري

التعرف على التلميحات وعلاقتها بالأسلوب المعرفي في التعلم النقال وأثرهما على تنمية مهارات إنتاج الإنفوجرافيك والتفكير الابتكاري، وذلك في تسعة محاور وهى: المحور الأول: التعلم النقال، المحور الثاني: الإنفوجرافيك، المحور الثالث: التلميحات، المحور الرابع: الأسس والمبادئ النظرية التي يقوم عليها البحث، المحور الخامس: معايير تصميم بيئة التعلم النقال في ضوء نمط التلميحات (المكتوبة/ اللونية)، المحور الساد: الأسلوب المعرفي، المحور السابع: التفكير الابتكاري، المحور الثامن: العلاقة بين نمطي التلميحات والأسلوب المعرفي وتتمية المهارات، المحور التاسع: نموذج التصميم التعليمي المستخدم في البحث الحالي، وفيما يلي عرض لهذه المحاور: المحور الأول: التعلم التقال تعريف التعلم النقال:

للتعلم النقال مسميات أخرى فيطلق عليه البعض التعلم الجوال أو التعلم المتتقل أو التعلم بالموبيل أو التعلم المحمول، فيعرف تراكلر

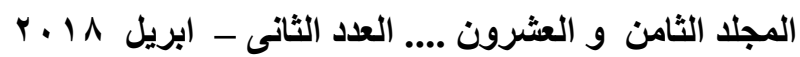


الجمعية المصرية لتكنولوجيا التعليم

مع المتعلمين، التتقل فالتعلم يتم في أي وقت ومكان فالتنقل يتوفر في أربعة مجالات هي: التنقل في الفضاء المادي بعيدًا عن قيود الفصول الدراسية؛ التنقل في الفضاء التقني من حيث توفر الأجهزة النقالة لاى المتعلمين؛ التنقل في الفضاء المفهومي حيث يعطي المتعلم حرية التنقل من موضوع إلى آخر ومن مفهوم إلى آخر على الانترنت من خلال الأجهزة النقالة؛ التنقل في الفضاء الاجتماعي من حيث إتاحة تعاون المتعلم مع أقرانه لتسهيل إنجاز المهمات التعليمية، الاتصالية وذلك من حيث إتاحة الأجهزة النقالة للمتعلم استخدام كثيرًا من أدوات الأتصال المتاحة عبر الانترنت، النشاط التعليمي المبني على الموقف من خلال ارتباط المتعلم بالحياه اليومية فيستمد خبراته العلمية والعملية من خلال الممارسات اليومية بحيث تقام المشكلات والمعلومات ضمن سياقها الأصلي بحيث يكون المتطلم فكرة واضحة عنها تساعده على إيجاد حلول مناسبة، تكامل المحتوى التعليمي، السياقية حيث يجري التعلم النقال ضمن أكثر من سياق؛ فيقصد بسياق التعلم النقال أنه أي معلومات يمكن توظيفها لتمييز مواقف التعلم المتصلة بالتفاعل بين المتعلم وأي تطبيق من تطبيقات التعلم النقال؛ فتتمثل هذه السياقات في السياق المكاني والزماني؛ سياق الأجهزة؛ سياق الواقع الافتراضي؛ السياق

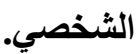

والتفاعل وتوصيل المحتوى التي تحدث خارج الجدران، أثناء تنقل المتعلمين في سيقات بيئية موقفية متعددة في أي مكان ووقت، بإستخدام الأجهزة الإكترونية النقالة، مثل المساعد الرقمي الثخصي، والكمبيوتر الكفي، والمحمول، والتليفونات الذكية، والتليفونات الخلوية، وأي أجهزة إلكترونية محمولة أخرى.

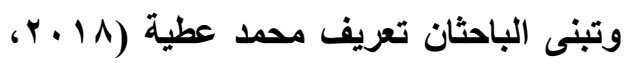
ص1 V^) وذلك لأنه تعريف شامل من حيث جعل المتعلم محور العملية التعليمية، إجراء التعلم في أي وقت ومكان، ويعتمد التعلم على عدد متنوع من الأجهزة الرقمية النقالة التي تتميز بسهولة حملها والتنقل بها، أيضًا قدرة المعلم على التواصل بفاعلية مع المتعلمين لتقديم التلميحات اللازمة لهم في أي

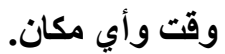
خصائص التعلم النقال: للتعلم النقال خصائص عديدة منها ما ذكره (Fotouhi, Earnshaw, Moeini, ل من Robison \& Excell, 2011, pp. 17-25; Chen, Kao, \& Sheu, 2003, pp. 347(348 وهي: الاستجابة لحاجات التعلم الملحة كالبحث سريعًا عبر الانترنت من خلال الأجهزة النقالة عن إجابة سؤال ما أو التأكد من صحة معلومات ما أو إثراء التعلم، المبادرة إلى إكتساب المعرفة من خلال إتاحة الأجهزة النقالة بصفة دائمة

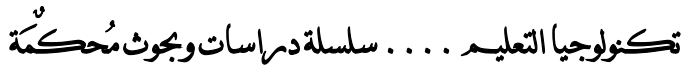


مع التعلم النقال أنماط تعليمية أخرى؛ التشاركية في التعليم؛ أن يكون تابعًا لموقع بحيث يمكن إتاحة

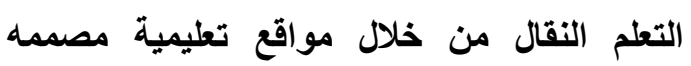
خصيصًا لهذا الغرض. وقد حاول الباحثان الإستفادة من هذه الخصائص وخصوصًا في طبيعة عملية التعلم من حيث إتاحة المحتوى للطلاب في أي وقت وند ومكان، وإتاحة التفاعل بين المعلم والمتعلمين وبعضهم البعض، أيضًا المرونة في تقديم الأنشطة والتكليفات وأيضًا تقديم التلميحات إلى المتعلمين كل حسب قدراته واستعدادته النفسية، وإتاحة التشارك بطريقة إيجابية فيما بين المتعلمين وبعضهم ولهنه

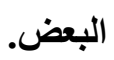

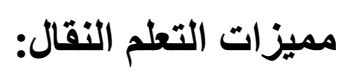

للتعلم النقال عديد من المميزات، فيذكر كل من

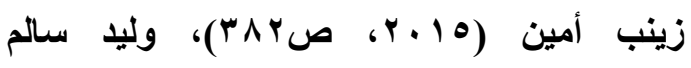

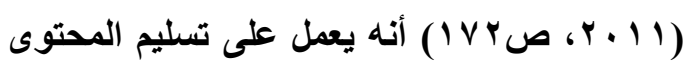
بأكثر من شكل، كما أنه يسمح للمتعلم بإضافة قائمة وعناوين الموضوعات التي يمكن أن يتناولها بعد (Hamdan, اليوم الدراسي، ويضيف حمدان 2008, pp.31-35) التعلم الإكتروني تطورًا، لأنه يوفر فرصه للتعلم في أي وقت وأي مكان، وبتوفر الأجزةة النقالة مع المتعلمين يساعد ذلك في مراعاة الفروق الفردية والخصوصية في التعلم، ويذكر عبدالرحمن سالم

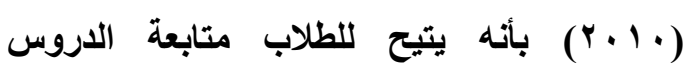
والتمارين التدريبية والتعلم الذاتي، وإرسال أعمالهر

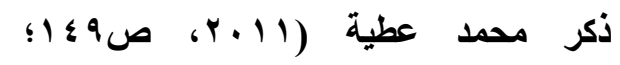

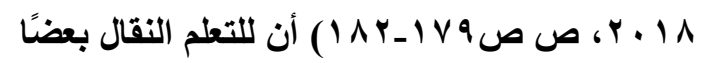
من الخصائص التي تميزه هي: الحمل والتنقل، فالتعلم النقال يحدث خارج الجدران. ويمكن للمتعلم استقبال التعلم في أي مكان، باستخدام الأجهزة

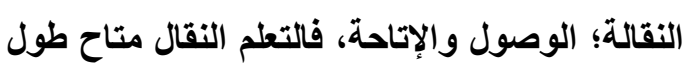
الوقت، وفي أي مكان. حيث يمكن للمتعلم الوصول

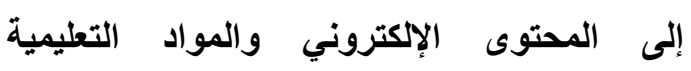
والندوات، وإلى المعلم، والمتعلمين الآخرين، وإلى الإلى

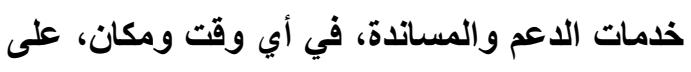
مدار الساعة؛ المرونة، والمرونة تعني في أي وقت ومكان. والتعلم النقال يقوم على أساس الاتصالات اللاسلكية، وبالتالي يمكن للمتعلم الوصول إلية في

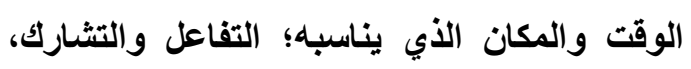

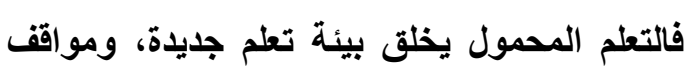
تعليمية جديدة، تقوم على أسناس التفاعل والتعلم

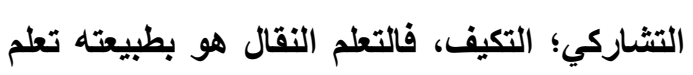
تكيفي، بمعنى أنه يتكيف مع حاجات المتعلمين المختلفة؛ والتحكم والدعم وهو التحكم في عملية التعلم النقال ومتابعة المتعلم؛ والقابلية للاستخدام

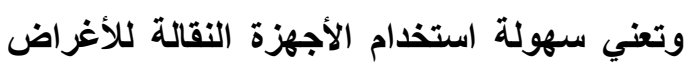

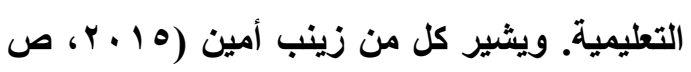

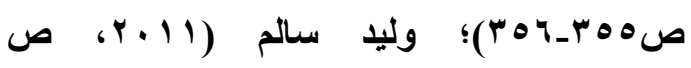

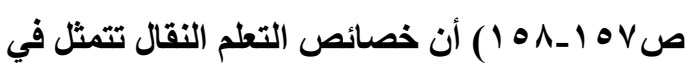
ست خصائص هي: التواجد في كل مكان؛ صغر الحجم من حيث الأجهزة وأيضًا المحتوى المقدم؛ تحت الطلب؛ الخلط/ الدمج النمونجي بحيث يدمج ولفي الاجني 
الجمعية المصرية لتكنولوجيا التعليم

ومكملًا لوسائل التعليم الأخرى أكثر من أن يكون بديكَا لها، أيضًا يوفر التعلم النقال قدر كبير في المرونة حيث يتم التعلم وفق احتياجات المتعلمين، يسهل عملية البحث العلمي أثثاء جمع البيانات وتحريرها وتداولها، يزيد التعلم النقال من الدافعية والالتزام الثخصي والمسئولية للمتعلم حيث يكون المتعلم هو محور العملية التعليمية. جميع المميزات السابقة للتعلم النقال باعتباره أحد التطورات للتعلم الإكتروني والتعلم من بعد وأيضًا باعتباره تعلم يتمركز حول المتعلم حيث تقع المسئولية كاملة على الطلاب لتقصي المعلومات مع تقديم التلميحات اللازمة لهم، مما يتيح فرصة المتعلمين على العمل والإنتاج خارج نطاق التعليم الرسمى وربط المعارف النظرية بالمهارات العملية وذلك من خلال الأجهزة النقالة التي يستخدمها المتعلمين، وإتاحة فرص العمل الجماعي والتعاونى كالتفاعل والتشارك والتعاون فيما بينهم في أداء المهمات التعليمية، لذلك يتضح للباحثان من خلال مميزات التعلم النقال أن تقديم التلميحات للمتعلمين في بيئات التعلم النقال أمرًا ضروريًا وذلك لأن تلك البيئات تتميز بحرية تجوال المتعلم أثناء تعلمه، فلذلك تعد التلميحات هي الموجه لهم نحو عملية التعلم ، وفي هذا البحث سيتم دراسة أثر التفاعل بين نمط التلميحات (المكتوبة/اللونية) والأسلوب المعرفي (الاعتماد/الاستقلال) على تتمية مهارات
إلى بعضهم البعض، كما يمكنهم وضع المواعيا النهائية لتحميلها على مفكراتهم الرقمية، والبحث من خلال الانترنت، يصل إلى أكبر عدد من الطلاب في أماكن مختلف، يتظلب على نقص أجهزة الكمبيوتر بالمؤسسات التعليمية، يعالج كثير من أوجه قصور التعلم بالطرق التقليدية، يتميز بسهولة تطبيقة، يعد شكلا جديدًا من أشكال نظم التعليم من بن

Attewell, 2005, p.13; ) يشير كل من Rayn, 2007 رفيق البربري، حنان عبدالسلام،

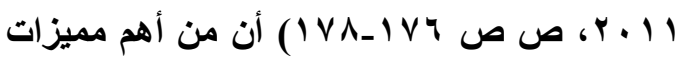
التعلم النقال أنه يتيح للمتعلمين التطبيق الفوري للمهارات والمعلومات، كما يتيح للمدرس أستعراض ومتابعة تنفيذ المهمات والتكليفات الخاصة بموضع التعلم، يتيح بسهولة تبادل الملفات والكتب الإكترونية بين المتعلمين وبعضهم البعض، يمكن المتعلمين من التسجيل الإكتروني وإدخال البيانات أثناء الدروس العملية أو الخارجية عندما لا تكون الحاسبات المكتبية غير مناسبة، يمكن من خلالها توصيل المعلومات المسموعة والمكتوبة والمرئية في نفس الوقت الحقيقي، تتميز بعض الأجهزة الأكية بإمكانية الكتابة بخط اليد وأيضًا بالقلم مما بـا يجعل استخدامها أكثر سهولة، يمكن من المشاركة في تنفيذ العمليات والمهام بشكل جماعي وتثشاركي، تثجع المتعلمين على التعلم الأتي، تحقق مفهوم التعلم الفردي، يمكن اعتبار التعلم النقال متممًا

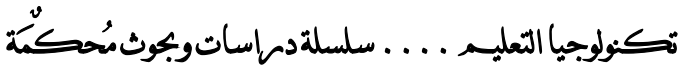


الجمعية المصرية لتكنولوجيا التعليم

(2016) فاعلية استخدام التعلم النقال في تنمية

التحصيل الدراسي من خلال التفاعل والحوار

المتبادل بين طلاب الجامعة بعضهم البعض. وأثبتت

Thornton, \& دراسة ثورونتون وهاوسر (2005) (اعلية استخدام التعلم النقال أدى House (2005 إلى تنمية الأداء والإنجاز لاى الطلاب بكفاعة عالية. وأثبتت دراسة ياتج (2012) Yang فاعلية استخدام التعلم النقال في تنمية الاتجاهات والكفاعة الأتية لتعلم اللفة الانجليزية لاى طلاب الجامعة. وأثبتت دراسة ميليفيا Miliva (2011) فاعلية استخدام التعلم النقال في تنفيذ المهام والتكليفات بشكل فعال من خلال توفير المعلومات والتوجيه والإرشاد متى وأين تكون الحاجة إليها. وأثبتت

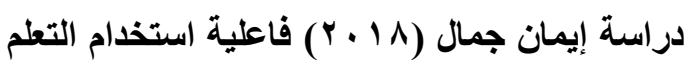
النقال في تنمية التحصيل المعرفي ويعض مهارات برمجة قواعد البيانات لدى طلاب تكنولوجيا التعليم.

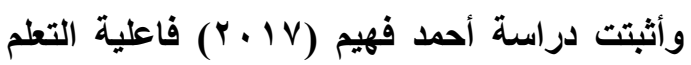
النقال في تنمية الدافعية للإنجاز، والتحصيل المعرفي لدى تلاميذ المدرسة الإعدادية. وأثبتت دراسة حمادة محمد، وأيمن محمد (7 1 • ب) فاعلية استخدام التعلم النقال في تنمية مهارات البحث العلمي لاى طلاب الاراسات العليا. وأثبتت دراسة هاني شفيق († 1 • ץ) فاعلية استخدام التعلم النقال في تنمية الجانب الأدائي لمهارات التعامل مع

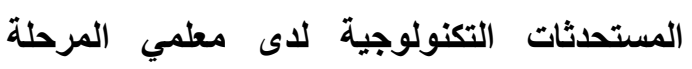
الإعدادية. وأثبتت دراسة أحمد صادق (10)
إنتاج الإنفوجرافيك والتفكير الابتكاري لاى طلاب

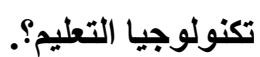
فاعلية استخدامات التعلم النقال: ترجع أهمية استخدامات التعلم النقال بأن له فوائد مرتبطة بتحسين التحصيل والأداء المهاري، التفكير الناقد، والتفكير الابتكاري، وحل المشكلات المعقدة، نقل التعلم، والاتجاهات الإيجابية نحو المهمات، وأيضًا أثبت فاعلية في العديد من النواحي التعليمية. وهذا ما أكدته كثيرًا من الاراسات والبحوث، كدراسة كرومبتون، وبورك Crompton, and Burke (2018) فاعلية استخدام التعلم النقال في تنمية التحصيل المعرفي ومهارات إعداد البحوث العلمية لدى طلاب

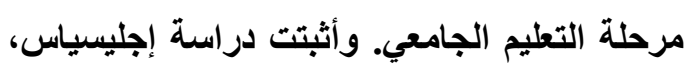
Iglesias, García, and جارسيا، وسانشيز فاعلية استخدام التعلم النقال Sánchez (2017) في رفع كفاءة تلاميذ المرحلة الإبتدايئة في إنجاز

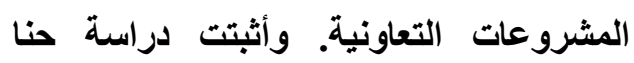
Hanna (2017) التحفيز الإيجابي للطلاب نحو التعلم وزيادة الأداء الأكاديمي وتحسين اتجاهاتهم الإيجابية نحو

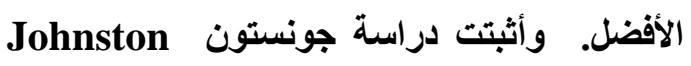
(2016) فاعلية استخدام التعلم النقال في تنمية التفاعل بين المتعلمين بعضهم البعض في إنجاز

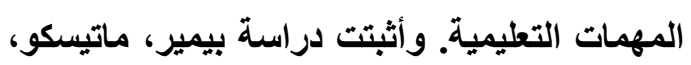
Pimmer, Mateescu, \& Gröhbiel وجروبيل 
التعليم، ونظرأ لأهمية الإنفوجرافيك في تحويل البيانات النصية إلى رسومات وصور مما يساعد المتعلمين على الفهم والإستيعاب بسرعة وجذب الانتباه نحو عملية التعلم، ويعد أيضًا إتقان طلاب تكنولوجيا التعليم مهارات تصميم الإنفوجرافيك متطلب أساسي كأحد المهارات اللازمة لاى أخصائي تكنولوجيا التعليم. وهذا ما أكلته كثيرًا من الدراسات و البحوث كما تم ذكره سابقًا. المحور الثاني: الإنفوجرافيك تعريف الإنفوجر افيك:

توجد الكثير من تعريفات الإنفوجرافيك ولكنها تدور حول مفهوم واحد، فعرفها سميسيكلاس Smiciklas (2012, p. 3) بأنه نوع من الصور يمزج بين البيانات مع التصميم، لمساعدة الأفراد والمؤسسات على توصيل الرسالة بكفاءة بشكل مختصر إلى الجمهور وذلك من أجل فهم الأفكار والمفاهيم وزيادة القدرة على التفكير النقدي وتحسين الاحتفاظ بالبيانات، وعرفه سالاس رودا Salas Rueda (2015, p. 38 بأنه تمثيل مرئي للبيانات والمعلومات والمفاهيم المعقده لتقليل النصوص عن طريق الجمع بين أقل عدد من الكلمات والصور بأنوعها المختلفة، مما يسمح للمشاهدين الفهم بسرعة للأفكار الأساسية المراد توصيلها لهم.
فاعلية استخدام التعلم النقال في تنمية مهارات الانخراط في التعليم وتصميم وحدات رقمية. وأثبتت

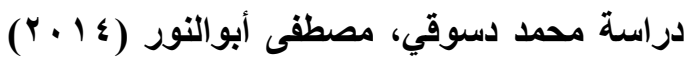
فاعلية استخدام التعلم النقال في تنمية التحصيل المعرفي ومهارات استخدام تطبيقات الهواتف الذكية لاى معلمي التعليم الأساسي. وأثتبت دراسة ومختار

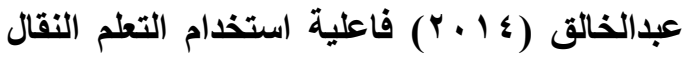
في تنمية الاتجاهات الإيجابية نحو استخدامه.

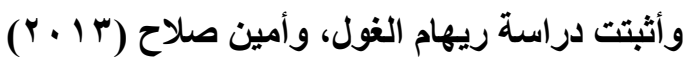
فاعلية استخدام التعلم النقال في تنمية مهارات إنتاج البرامج الإكترونية التفاعلية لاى أعضاء هيئة التدريس في جودة المنتج النهائي. وأثبتت دراسة الته

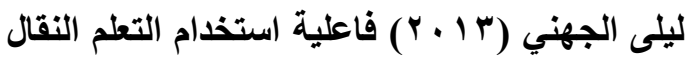
في تدريس بعض مفاهيم التعلم الإكتروني وموضوعاته لاى طالبات قسم الطفولة. وأثبتت

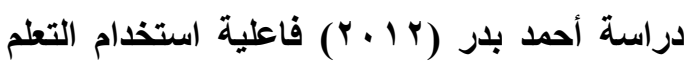
النقال في اكساب المتعلمين المفاهيم والمصطلحات التكنولوجية وتكوين اتجاهات ايجابية لديهم نحو التعلم النقال. وأثبتت دراسة رفيق البربري، وحنان عبدالسلام (11 • ץ) فاعلية استخدام التعلم النقال في علاج الأخطاء الترريسية الثائعة في تنفيذ الارس لاى معلمي المرحلة الثانوية. لذلك فإن التعلم النقال له فوائد عديدة عند استخدامه في تنمية مهارات إنتاج الإنفوجرافيك والتفكير الابتكاري بمقرر إنتاج الرسوم التعليمية لاى طلاب الفرقة الثانية تخصص تكنولوجيا

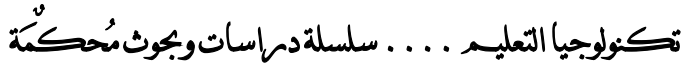


الإكتروني القائمة على الويب. ويتسم بقدرته الإثرائية من حيث إمكانية إضافة الروابط وعناوين الانترنت التي يمكن للمتعلم الرجوع إليها لإثراء

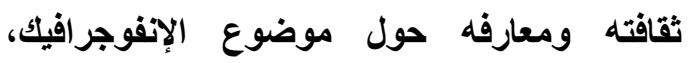
وإضافة عناوين بعض الكتب، الملخصات، الاراسات، والأبحاث ذات الصله بالموضوع. وكذلك يتسم بالتصميم الجذاب من حيث التوع بين استخدام الألوان، والصور، والرسومات، والخطوط، و هذا يسهم في قدرة الإنفوجر افيك في مخاطبة جميع الأعمار والثقافات. ويتسم أيضًا بإبداعية الفكرة من حيث تقديمه المحتوى بشكل إبداعي مستخدما الصور والرسومات التي تعمل على خلق جو تعليمي جذاب وتفاعلي. كما يضيف ماتركس، وهودسون أن Matrix, \& Hodson (2014, pp. 17-27) الإنفوجرافيك التعليمي يتسم بقرته على تنظيم الأفكار بطريقة مفيدة، وإظهار العلاقات المعقدة بطريقة مرئية، ومقارنة المعلومات بطريقة فعالة، وجعل البيانات ذات مغزى مع القياس والأمثئة، والموضوعات لتحويل البيانات إلى معلومات، وتنقل الأفكار والكلمات مع الصور بطريقة مثيرة بلئًا من استخدام كلمات فقط. المميزات والإمكانيات التعليمية للإنفوجر افيك: للإنفوجرافيك مميزات وإمكانيات تعليمية عديدة، فحددها كل من محمد الصاوي (r . . ץ، ص

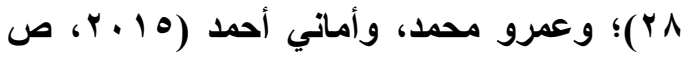

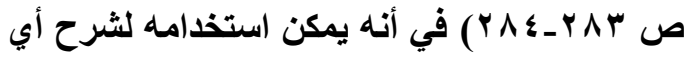

ويعرف الإنفوجرافيك إجرائيًا بأنه تحويل

المواقف التعليمية التي تحتوي على كم كبير من النصوص إلى أثكال مرئية معتمدًا في ذلك على الصور والرسومات والأيقونات، لتسهل على المتعلم فهمها بطريقة أيسر وأسرع وقت ممكن، واقتصر البحث الحالي على الإنفوجرافيك الثابت المنتج بواسطة برنامج الفوتوشوب. خصائص الإنفوجر افيك:

للإنفوجرافيك خصائص عديدة منها ما ذكره كل من (تامر المغاوري، وياسر خضير،

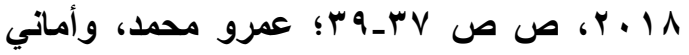
Dai, أحمد، 10 Siting, 2014, p.16; Semetko, \& (Scammell, 2012; Lester, 2006, p. 181; أنه يتسم بالقدرة على ترميز المعلومات، والمفاهيم، والحقائق، والمعارف في رموز مصورة، وقدراته على اختصار وقت التعلم، والأمكانية في اختزال واختصار العديد من الصفحات المتعلقة بموضوع التعلم في تصميم واحد، كما يوفر عملية عرض محتوى التعلم المشتمل على تفاصيل كثيرة بطريقة إطار بعد إطار دون التأثير على جودة الصورة الأصليه؛ بلَّا من عرضها كصورة واحدة كبيرة الحجم. أنه يتسم أيضًا بسرعة الاتصال البصري وذلك عند صياغة المعلومات في صورة بصرية يجعلها أسهل للفهم والترميز داخل العقل البشري. ويتسم أيضًا بالقابلية للمشاركة عبر شبكات التعلم

المجلد الثامن و العشرون .... العدد الثانى ـ ابريل 1 1 ـ ץ 
الجمعية المصرية لتكنولوجيا التعليم

تعليمية متتوعه معرفية ومهارية ووجدانية في موضوعات عديدة وكل المستويات التعليمية، مناسبتها لجميع الإجراءات والأحداث التعليمية بلاءًا من استثارة الدافعية وحتى التقويم، مناسبتها لأنماط التطليم المختلفة للأفراد والجماعات الصغيرة والكبيرة، سهولة إنتاجها بتكاليف ومهارات بسيطة، و سهولة نقالها وحفظها وتخزينها، وهذه المميزات الخاصة بالصور التعليمية تنطبق أيضًا على الإنفوجرافيك التعليمي.

نوع الإنفوجرافيك المستخدم في البحث الحالي: توجد عدة أنواع للإنفوجرافيك هي الثابت، والمتحرك، والتفاعلي وهذه الأنواع مقسمة حسب Matrix, \& Hodson, 2014; Dai, ) الشكل Siting, 2014, p.17 ; Smiciklas, 2012, p.7)، ولكن البحث الحالي يقتصر على استخدام الإنفوجرافيك الثابت، للأسباب التالية: أنه متطلب أساسي كأحد الموضوعات التي يجب على خريج تكنولوجيا التعليم دراستها بمقرر إنتاج الرسوم التعليمية وأن يكون ملمًا بمهارات الإنتاج والتصميم الجيد لتوظيفه لخدمة العملية التعليمية، أن إنتاجه يتطلب من المتعلمين أن يكونوا على دراية كبيرة بأحد برامج تصميم الجرافيك كبرنامج الفوتوشوب، الإنفوجرافيك الثابت ما هو إلا مجموعة من الصور، والرسومات، والأسهم، والنصوص الرئيسية والفرعية والروابط والأثكال التي تعرض جميعها في شكل واحد ثابت، فتعد هذه المكونات جميعها يتم
معلومة في أي مجال تعليمي، وهو أوستح انتشارًا من الفيديو والكتابة، وذلك لأنه يختصر الكثير من الكتابة والصوت والصور في رموز وصور تعبيرية ودلالات بسيطة، ويقدم الحقائق العلمية في صور معلومات بسيطة، يُمثل جزءًا كبيرًا من خبرات الناس في التعرف على العالم المحيط بهم، ويعد أداة مثالية لتوضيح شكل الأشياء غير المألوفة سواء كانت ذات طابع خاص أو تمثل مفهومًا عامًا، إمكانية حذف التفاصيل غير المرغوب فيها وغير الضرورية أثناء المعالجات الجرافيكية والتصميم، يضغط الواقع أو يغير فيه لأهداف التعلم فيكبر الصغير ويصغر الكبير لأمكانية فهمه ودراسته، أيضًا يقدم أوصاف دقيقة حول مظهر الأشياء بإستعمال الأشكال والملمس والتراكيب المماثلة للشكل الأصلي، ويضيف عاصم محمد (7 1 + Y، ص

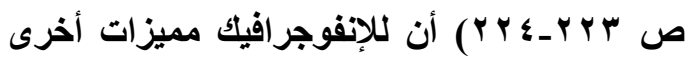
منها مساعدة المتعلمين على الأحتفاظ بمحتوى التعلم وزيادة التركيز، الأسهام في توصيل الرسالة والهرف التعليمي بسرعة نظرًا لتركيز المعلومات بثكل بصري، يساعد في المساهمة في تكوين تصور عقلي سليم وتعديل التصورات الخاطئة لاى المتعلمين، يعتبر وسيلة جذابة للتقديم لموضوع التعلم كما أنه يستطيع إثارة فضول المتعلمين بطريقة لا تقرر عليها البيانات المعقدة، وذكر محمد

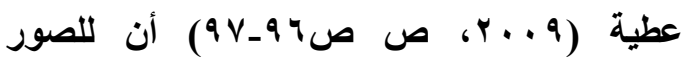
التعليمية مميزات هي مناسبتها لتحقيق أهداف

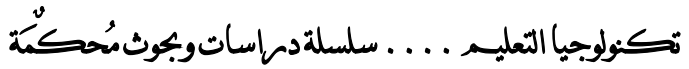


البعض، عند إتقان خريج تكنولوجيا التعليم مهارات إنتاج وتصميم الإنفوجرافيك قد يفتح أمامه مجالَّا للإلتحاق بسوق العمل ومواكبة التظورات العصرية، ويسهم في تكوين تصور عقلي سليم أو تعديل التصورات الخاطئة لاى المتعلمين. مهارات تصميم الإنفوجر افيك الثابت: يحتاج تصميم الإنفوجرافيك إلى توافر مجموعة من المهارات، وقد حددت دراسة عادل عبدالرحمن، عبير عادل، وإيناس عبدالرؤوف

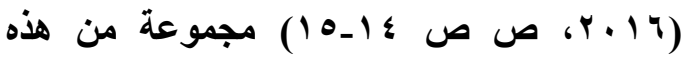
المهارات هي: مهارة التفكير الإبداعي والتخيل العقلي والمتمثل في التخيل البصري والتخيل المجازي وتخيل فكرة الموضوع، مهارة التمييز البصري والمتمثل في تحليل الثكل البصري وإدراك العلاقات في الثكل البصري وإدراك وتفسير الغموض، مهارة قراعة الصور والرسوم، مهارة الاتصال، مهارة تسجيل الأفكار والمعلومات المعقدة، مهارة إستخلاص المعاني، مهارة إستحضار المعلومات السابقة، مهارة التمثيل البصري للمطلومات من حيث التمثيل التصويري والتمثيل الرمزي، مهارة تحليل المعلومات، مهارة

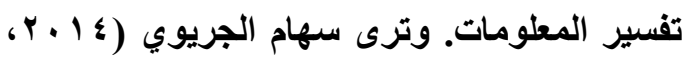

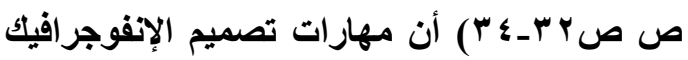
الثابت هي: مهارة الأدراك البصري من حيث الثكل والأرضية والتثابه والتقارب أو الجوار والإغلاق وإدرات العلاقات المكانية، مهارة قراعة البصريات
دراستها بمقرر إنتاج الرسوم التعليمية، أيضًا فله أهمية كبيرة في تحسين عملية التعلم لاى المتعلمين من حيث إثارة إنتبهاهم نحو التعلم وزيادة تفاعلهم، أيضًا من ضمن أسباب استخدام هذا النوع أنه سهل التداول والتشارك عبر بيئة التعلم النقال موضوع البحث الحالي، وأيضًا سهولة تقديم التلميحات سواء المكتوبة أو اللونية على الإنفوجرافيك الذي تم إنتاجه بواسطة الطلاب عبر بيئة التعلم النقال، وغير ذلك لكي يصبح خريج تكنولوجيا التعليم مواكبًا للتظورات الحادثة في العصر الذي نعيثة اليوم، وذلك بإعتبار الإنفوجرافيك أحد مجالات الدعاية والإعلان ويذلك يصبح الخريج مؤهلَا للألتحاق بسوق العمل بصفة عامة. وظائف استخدام الإنفوجرافيك في البحث الحالي: يستخلم الإنفوجرافيك في البحث الحالي ضمن مقرر إنتاج الرسوم التعليمية الذي يلرسه طلاب تكنولوجيا التعليم بالفرقة الثانية، وذلك ليقوم بالوظائف التالية: بأن له فاعلية مؤثرة من خلال تحويل المحتوى النصي إلى رسومات وصور وأشكال جذابة التي تعمل على الاستيعاب السريع لاى المتعلمين واستثارة دافعيتهم نحو التعلم، يساعد في تقليل الوقت المستغرق لاراسة محتوى تعليمي وذلك بالإعتماد على الأشكال البصرية، المساعدة في الأختزال البصري لكمية كبيرة من المعلومات النصية لاى المتعلمين، سهولة وسرعة الاجرال تداول وتثارك الإنفوجرافيك بين المتعلمين بعضهم 
الجمعية المصرية لتكنولوجيا التعليم

الفني للإنفوجر افيك. وأضاف كل من عمرو محمد ،

وتتمثل في التعرف والأستدعاء اللفظي وغير

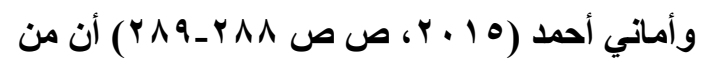
اللفظي والوصف والمقارنة والتصنيف والترتيب

ضمن مهارت تصميم الإنفوجرافيك الثابت مهارة والاستخدام المباشر للعلاقات والتفسير والتنبؤ، الإقناع البصري وذلك عن طريق التعبير عن ومهارة الإنتاج البصري. وأضاف عاصم محمد الرسالة المراد توصيلها بطريقة فعالة عن طريق

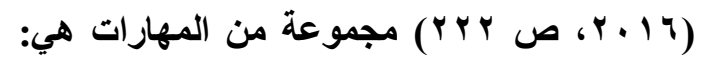
استخدام الألوان الحقيقية والجذابة ذات الصلة مهارة تحليل المحتوى المراد تحويله إلى بموضوع الإنفوجرافيك، مهارة اختيار الرسومات إنفوجرافيك، مهارة البحث عن البيانات والمعلومات

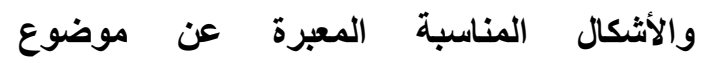
والصور الداعمة للإنفوجرافيك، مهارة إنتقاء الإنفوجرافيك، واقتصر البحث الحالي على مهارات البيانات والمطلومات وتنظيمها وتنسيقها، مهارة تصميم الإنفوجرافيك الثابت التالية: التخطيط المبئي للإنفوجرافيك، مهارة الإخراج أولَا: مهارة التفكير الإبداعي والتخيل العقلي ويتفرع منها المهارات الفرعية الآتيه: ا ـ التخيل البصري وهو التخيل في توضيح الظاهرة العلمية معتمدًا على تخيلات علمية مبنية على إدراكات حقيقية. r ـ التخيل المجازي وهو استخدام المتثابهات لتوضيح ظاهرة أو مفهوم ما وتقريبه للمتعلم. rـ تخيل فكرة الموضوع وهو التركيز على المفاهيم الأساسية في الموضوع. ثانيًا: مهارة التمبيز البصري ويتفرع منها المهارات الفرعية الآتيه:

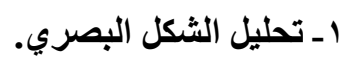
r - إدراك العلاقات في الثكل البصري. بـ - إدراك وتفسير الغموض.

ثالتًا: مهارة التمثيل البصري للمعلومات ويتفرع منها المهارات الفرعية الآتيه: 1ـ تمثيل تصويري ويعتمد على التظيم البصري وغيره من أنواع التظيم الحسي، ويعتمد على استخدام الصور التخيصية للآثياء فتحل الصورة البصرية محل الثىع الفعلي. r ـ تفسير رمزي وتعني استخدام الرموز و الأشكال للتعبير عن المعاني والأفكار. 
رابعًا: مهارة تحليل المعلومات: من حيث التركيز على التفاصيل الاقيقة والأهتمام بالابيانات الجزئية والكلية. خامسًا: مهارة تفسير المعلومات: من حيث القدرة على تفسير كل جزئيات الثكل البصري، من خلال فهم وفلك الرموز والإشارات المتضمنه بها وذلك للوصول للنتيجة وإستنتاج المعنى.

الأساسية داخل صندوق الأدوات بيرنامج الفوتوشوب، التعرف على وظيفة اللوحات داخل برنامج الفوتوشوب، استخدام أدوات التحديد داخل برنامج الفوتوشوب، التعامل مع الرسوم داخل برنامج الفوتوشوب، التعامل مع النصوص داخل برنامج الفوتوشوب.

ويرى الباحثان أنه عند تعلم الطلاب مهارات تصميم وإنتاج الإنفوجرافيك الثابت من خلال بيئة التعلم النقال لابد من توجيهـم نحو موضوع العلم، وذلك من خلال تقديم التلميحات لهم نظرًا لعدم تثتيت إنتباههم وتركيزهم على تتفيذ الأنشطة والمهمات و التكليفات المطلوبه منهم بإتقان. المحور الثالث: التلميحات

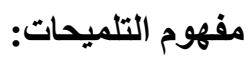
للتلميحات تعريفـات عديدة ولكنها تدور حول معنى واحد، فعرفها كل مـن حسن شـحاته، زينب

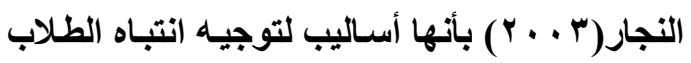
لنقطة معينة محل التدريس حتى يتم التركيز عليها، ويعرفهــا تـابيرس، مـــارتينز، وميرينبـوير Tabbers, Martens, \& Merrienboer (2004, p.71) موضـوع الـتـطم وذلـــك بغـرض إكســابهم بعـض

$$
\text { ولتحقيق المهارات السابقة يجب على الطلاب }
$$

إتقانهم مهارات أحد برامج إنتاج الرسومات ومعالجة الصور كبرنامج الفوتوشوب، أو الأليستريتور، أو غير ها من البرامج، ولكن الباحثان Adobe قاموا بتحديد برنامج الأدوبي فوتوشئوني Photoshop الإنفوجرافيك الثابت، وأيضًا لما يتميز به من مميزات هائلة تجعله يأخذ الصداره في اختيار الباحثان له مثل قدرته الفائقة على تعديل وانتاج مختلف أنواع الرسوم والصور وكتابة النصوص هن بشكل رسومي، وإضافة تأثيرات لونية وهذا كله يحتاجة الإنفوجرافيك عند تصميمه. وقد تعددت المصادر سواء العربية أو الأجنبية التي تناولت مهارات استخدام برنامج الفوتوشوب التي يمكن توظيفها في إنتاج الإنفوجرافيك، وقد اطلع الباحثان على عديد منها إلا أنه اعتمد في اشتقاق قائمة المهارات الأساسية التي يود أن يتعلمها الطلاب لإنتاج الإنفوجرافيك الثابت على كتب هي مجدي أبو

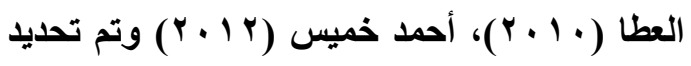
تلكك المهارات في ست مهارات رئيسة وينبثق من كل مهارة رئيسية مجموعة من المهارات الفرعية الأخرى، والمهارات الرئيسية هي: التعامل مع بيئة العمل ببرنامج الفوتوشوب، التعامل مع الأدوات

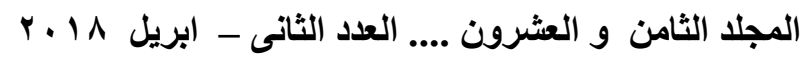


الجمعية المصرية لتكنولوجيا التعليم

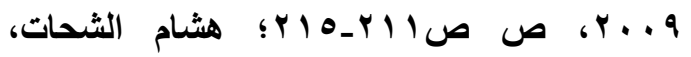

المعلومـات والمعـارف المعينـة لجعل المفـاهيم التـي

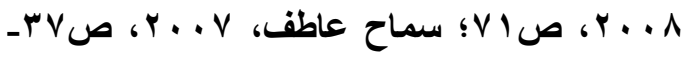

أخطأ فيها المتعلمين في كتابتهم متميزة عن غير هـا

Madsen, 2013, p. 14; Boucheix, مـن المفــاهيم الأخـرى، وتعـرف بأنهـا هـي إعـادة Lowe Putri, \& Groff, 2013, p. 78; توجيـه انتبـاه المتطفين إلـى الجوانب الهامـة التي (Brashear \& Baker, 2008 وقام الباحثان بإستخلاص الخصائص التالية للتلميحات الجيدة تستحق جذب انتباههم والتقليل من بروز العناصر

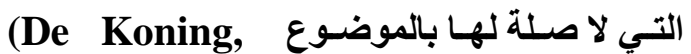

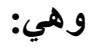
• التركيـز: لابــــ أن تكـون التلميحـات مركـزة على المعلومات الأكثر أهمية، وذلك لجذب

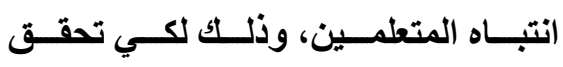
التلميحات الغرض منها في الوقت المحدد. • الاقـة والصحة: قد تكون التلميحات مركزة على المعلومــات ذات الصـلة ولكـن غيـر صحيحة ولا تناسب العرض المقدم، لذلك لابد أن تكون دقيقة وصحيحة.

• الاختصار والإيجاز: فهذا يسهل على المعلم تنظــيم العلاقـــات بــين الأفكـار وتــــكر التلميحات عندما يحين استخد/مها، وأيضًا تساعد المتعلمين على تذكرها بسهولية.

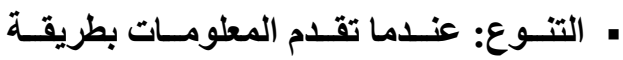
مبدعة فكل نوع من التلميحات قد يكون مفيد في مســاعدة المتعلمسين على ربط التعلم الجديـــــالتعلم السـابق والاسـتفادة منـه في المستقبل، وبـللك تحقق الهـف منهـا وهـو أن التلميحـات تســاعد المـتعلم 'Tabbers, Rikers, Paas, 2009, p.117) Lin, \& Atkinson وعرفها لين، وأتكينسون بأنهـا مثيـرات تقدم للمتعلمـين تساعدهم على جذب انتباه المتعلم للصفات المميزة للمفهوم. وتعرف التلميحات إجرائيًا بأنها توجيه الطلاب بـالنص المكتـوب أو اللـون نحسو مـا هـو المطلـوب تصميمه أو تعديله بالطريقة الصحيحة عند إنتاجهم للإنفوجرافيـك التعليمسي، بهـــ إثــــارة الانتبـاه، وتركيزه نحو جزء معين من الإنتاج وذلك لتحقيق الهـــف المنشــود، وذلــك لتحســين الـتـطم والأداء وتنمية التفكير الابتكاري من خلال التعلم ببيئة التعلم تعدد الاراسات والبحوث التي ذكرت خصائص التلميحات الجيدة عند تصميم البيئات الإكترونية

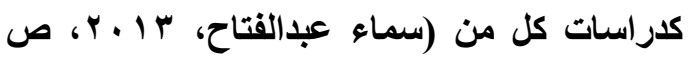

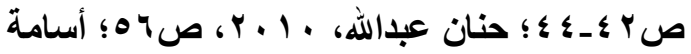
هنداوي، وحمادة مسعود، وإبراهيم يوسف، 
الجديدة، تساعد على سرعة توصيل الرسالة للمتعلم، وتعد التلميحات أسلويًا لتسهيل التعليم والحصول على تعليم فعال، أيضًا تساعد على تحسين إدراك وفهم المتعلم وإنتقال أثر التعلم De) Koning, Tabbers, Rikers, Paas, 2009; De Koning, Tabbers, Rikers, Paas, (2007. ويشير رويرتس (Roberts, 2009) أن التلميحات تساعد على تقليل الحمل المعرفي الخاص بموضوعات التعلم وتعزيز عملية التعلم، وتثير دراسة أسامة سعيد، صبري ابراهيم (^ . . ץ) أنها تعد معالجة يقصد بها إثارة وجذب انتباه المتعلم؛ ليتفاعل مع موضوعات التعلم، حتى يستطيع اكتساب المعلومات المطلوبة في النهاية. أكدت دراسات وبحوث كل من (إيمان صلاح،

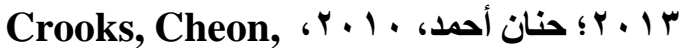
Inan, Ari, \& Flores, 2012; Lin, 2012; Lin, \& Atkinson, 2010; Tabbers, أن (Martens, \& Merrienboer, 2004; وظائف التلميحات تتمثل في الآتي: أنها تعمل على جذب الاتتباه حيث تعمل على توجيه انتباه المتعلم نحو المعلومات التي يجب أن تحظى بالاهتمام وتبعده عن المعلومات الأقل أهمية، تساعد على زيادة قرة المتعلم على الفهم والاستيعاب، تعل على الاحتفاظ بالمعلومات لفترة طويلة وذلك عن طريق ربط المعلومات الجديدة بالمعلومات السابقة
على فهم المعلومـات الجديدة وانتقال أثر

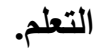

• الوضوح: يجب أن تكون التلميحات واضحة

ومفهومــة ومناسـبة للمسـتوى العقلـي

للمتعلمين وتراعي الفروق الفردية بينهخ.

• الجاذبيـة والإثارة: يجب أن تقدم التلميحات

بثـكل جذاب ومثيـر وذلـك لتوجيـه انتبـاه

المتعلمين إلي المعلومات الملمح إليها.

• الاستخدام الجيد: يجب تقديم التلميح بشكل

وظيفي حسب الحاجة التعليمية إليه حتى

يسـهل على المتعلم استرجاع المعلومـات

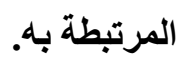

ـ مناسبة التلميح للمحتوي المعروض: يجب

أن تكــون التلميحـات ذات صـــة وثئــــة

بأهداف المحتوى التعليمي المقدم، حتى لا تعمل على تثتيت انتباه المتعلمين.

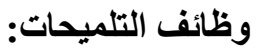

ترجع أهمية التلميحات في أنها تعمل على

تحسين عملية التعلم، وذلك من خلال توجيه انتباه المتعلمين إلى المعلومات المهمه في المحتوى الدراسي، أو عند تنفيذ المهمات والأنثطة التعليمية وذلك لتيسير فهمها واستيعابها لتحقيق الأهداف التعليمية، تساعد على دقة الانتباه، تجعل المتعلم أكثر استعدادًا للتطلم، تعمل على فهم المعلومات 
الجمعية المصرية لتكنولوجيا التعليم

\section{أـ التلميحات المكتوبة:}

هي أحد التلميحات اللفظية وتعرف بأنها عبارات

نصـية مــوجزة تســتخدم كطريقــة بديالــة لتوصـيل المعلومات المهمة والتركيز عليها، وتقدم للمتعلم أثناء تنفيذه للأنشطة والتكليفـات المطلوبـة منـه ومشــاركتها خلال بيئة التعلم النقال، وتظهر في حالـة وجود قصور أو ضعف في المنتج النهائي عند تنفيذه للتكليفـات على شكل نصوص مكتوبة وذللك لتركيز الانتباه، والتوجيه

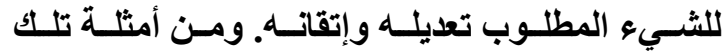
التلميحات: التسمية النصية، الأسئلة المكتوبة، التغيير في نـوع وحجم بنط الكتابـة، عبـارات نصية مـوجزة، ظهور واختفاء النص (أسـامة سعيد، صبري ابراهيم،

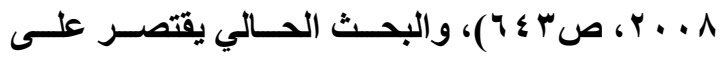
استخدام العبارات النصية الموجزة. تسـتخدم التلميحـات المكتوبـة بصـفة عامـة في تنميـة عديــــــن جوانـب الـتعلم كزيــادة التحصـيل

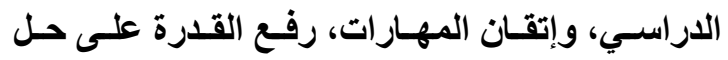
المشكلات، وخفض الحمـل المعرفي لـى المتعلمين، وتحسين إدراك وفهم المتعلم وانتقال أثر التعلم، وتقليل الوقت الذي يستغرقه المتعلم للبحث عن المعلومـات الأساسية في المـواد التعليميـة، تسـاعد المستخدم في

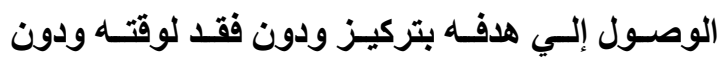
الخـوض في تفاصسيل غير مهمـة بالنسبة لـه وغير مرتبطة بـالمفهوم الأساسي، مسـاعده المتعلمين على فهم المعلومات الجديدة، إثراك المتعلمين في التعلم، ومنع وقوعهم في الخطأ، تسـاعد على سرعة توصيل
ذات الصله بموضوع التعلم، بالإضافة إلى عملية استرجاع المعلومات ترتبط أيضًا بجذب الانتباه والفهم للمحتوى المطلوب تعلمه حيث ينتبه ويفهم التلميح ثم يسترجع المتطلم المعلومات للاستخدام في المستقبل، تساعد أيضًا التلميحات على سرعة توصيل الرسالة عند مشاهلتها ما دامت مناسبة لمستوى فهم من يتلقونها. نمطا التلميحات المستخدمة في البحث الحالي: توجد عدة أنماط للتلميحات منها التلميح المكتوب، اللوني، الحركة، الموسيقى، الأسهم، الخطوط، ووضع خطوط تحت الكلمات، الرسومات المتحركة، الوضع في دائرة، الوضع في إطار، التأثيرات البصرية، التركيب، المنظمات المتقدمه، والتغير، الحداثة، الألفة، العرض المتعدد، التباين، التعقيد، كثافة المثير، التسمية، عنصر الدهشة، الغرابة، الأسئلة، التظليل، التكرار، الحجم، شفرة اللون، التثثيل، والغموض (الثحات عتمان،

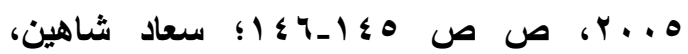
Roberts, 2009, p. 23; 19^v Brashears, Akers, \& Smith, 2005, p. 8; Dwrey, 1978, pp. 158-160 الحالي يقتصر على نمطين فقط هما: التلميحات المكتوبة، واللونية، كما يلي: 
اللونية الثابتة على الجزء المراد توجيه انتباه المتعلم

تستخلم التلميحات اللونية بصفة عامة في مساعدة المتعلمين على دقة الانتباه واستخدام الرموز المناسبة للمعالجة والتخزين في الذاكرة أي أنها تعمل على زيادة احتفاظ المتعلم بالمعلومات، وخفض الحمل المعرفي، يستخدها المتعلم بسهولة لاستعادة المعلومات من الذاكرة بعد فترات أطول، تقوم بدور الملخص والموضح فتوضح النقاط الغامضة وتظهر ها وتقوم بدور الملخص للموضوع ككل، تؤكد على موضوعات التعلم الرئيسية وتنظيمها، تساعد على جعل العلاقات بين العناصر أكثر بروزا لتعزيز التكامل بينها أي دمج العناصر في تمثيل متماسك أي أنها تؤكد العلاقة بين عنصرين داخل تمثيل واحد مثل (نص أو صورة) وتركز الانتباه إلي عناصر مترابطة في تمثيلات مختلفة مثل (نص وصورة)، تيسر من عملية القراءة وتساعد على التحصيل الجيد، أنها أسلوب لتسهيل التعليم والحصول على تعليم فعال، تساعد على جذب انتباه المتعلم للصفات المميزة للمفهوم (إيمان صلاح الدين، ب | + r؛ شيرين سعد، || + ب؟ حنان عبد

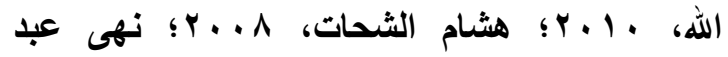
Liu, Lin, \& Paas, 2013; الحكم، ه. . ب؟ Lin, Kuo, Lin, Lin, Chang, \& Liu, 2012)، وتستخدم في البحث الحالي في تسهيل التمييز، وتركيز الاتتباه في عملية التعلم، وخفض الحمل المعرفي، وتتمية كل من التحصيل الدراسي،
الرسالة التعليمية، تجعل المتعلم أكثر استعدادًا للتعلم ، وتسـاعد على زيـادة سرعة العمليـة التعليميـة (صـافي

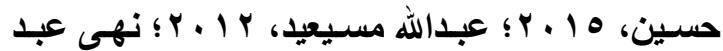

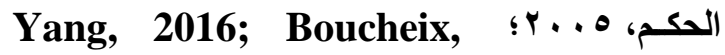
Lowe Putri, \& Groff, 2013; Kim, \& Gilman, 2008 وتسـتخدم فـي البحـث الحسالي لتقليل الوقت الذي يستغرقه المتعلم لإنجـاز الأنثطة التعليميـة، وتركيز الانتبـاه، وتنميـة كل مـن التحصيل

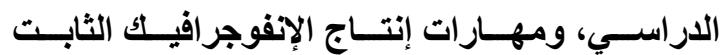
التعليمـي بإســتخدام برنــامج الفوتوشــوب، والتفكيـر الابتكـاري بمقرر إنتاج الرسوم التعليميـة لدى طلاب الفرقة الثانية تخصص تكنولوجيا التعليم من خلال بيئة

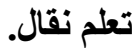

\section{بـ التلميحات اللونية:}

هي أحد أنماط التلميحات البصرية وتعرف بأنها مثيرات ثانوية باللون لتوجية انتباه وتركيز المتعلمين على المعلومات المهمة بموضوع التعلم، وتقدم لهم عند تنفيذهم للأنشطة والتكليفات المطلوبة منهم ومشاركتها خلال بيئة التعلم النقال، وتظهر لهم في حالة الحاجة إليها عند وجود قصور أو ضعف في المنتج النهائي. ومن أمثلة تلك التلميحات: وضع مساحات لونية ثابته، تلوين النص، وضع مساحات لونية متحركة، أسهم ملونة، تغيير باللون في الثكل والخلفية (Dwrey， 1978， pp. 158-160)، والبحث الحالي يقتصر على استخدام المساحات 
الجمعية المصرية لتكنولوجيا التعليم

والبعض الآخر أثبت فاعلية التلميحات اللونية

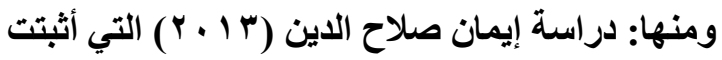
فاعلية استخدام التلميحات اللونية في رفع وتحفيز المتعلمين نحو عملية التعلم وخاصة عند التحصيل الدراسي، وأدائهم المهاري. وأثبتت دراسة ليو، لين، وباس (2013) Liu, Lin, and Paas استخدام التلميحات اللونية في تحسين التعليم من خلال بيئات التعلم النقالة. وأثتبت دراسة لين، كو، لين، لين، Lin, Kuo, Lin, Lin, Chang, تثانغ، وليو فاعلية استخدام التلميحات اللونية and Liu (2012) في خفض الحمل المعرفي لاى المتعلمين. وأثثتت دراسة شيرين سعد (11) فاعلية التلميحات اللونية في زيادة التحصيل الاراسي لاى الطلاب.

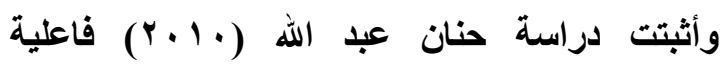
التلميحات اللونية في زيادة تحصيل الطلاب وأداء

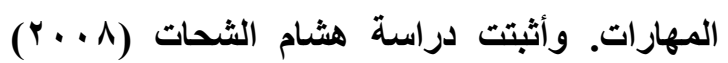
فاعلية التلميحات اللونية في تحفيز المتعلمين نحو عملية التعلم ورفع التحصيل الدراسي لاى الطلاب وتنمية اتجاهاتهم الإيجابية نحو تعلم الرياضيات. ولذلك توجد حاجة إلى المقارنة بين فاعلية كل من التلميحات المكتوبة واللونية في تنمية مهارات إنتاج الإنفوجرافيك الثابت التعليمي بإستخدام برنامج الفوتوشوب والتفكير الابتكاري لاى طلاب الفرقة الثانية تخصص تكنولوجيا التعليم، وهو ما يهرف إليه

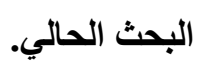

ومهارات إنتاج الإنفوجرافيك الثابت التعليمي بإستخدام برنامج الفوتوشوب، والتفكير الابتكاري بمقرر إنتاج الرسوم التعليمية لاى طلاب الفرقة الثانية تخصص تكنولوجيا التعليم من خلال بيئة تعلم نقال. مبررات استخدام نمطا التلميحات (المكتوبة/اللونية)

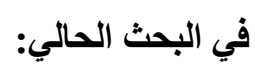
أجريت عدة بحوث ودراسات حول هذين النمطين ولكنها لم تقطع بأفضلية نمط على آخر، فبعض البحوث والدراسات أثبتت فاعلية التلميحات المكتوبة

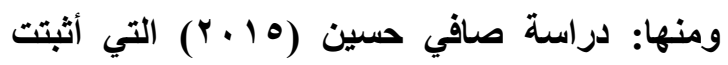
فاعلية استخدام التلميحات المكتوبة في تنمية التحصيل وحل المشكلات لاى الطلاب. وأثبتت دراسة عبدالله مسيعيد (Y Y • Y T) أن فاعلية التلميحات المكتوبة في تحسين التحصيل الفوري والمرجأ للمفاهيم الرياضية. وأثبتت دراسة ياتج (2016) Yang فاعلية التلميحات المكتوبة في المساعدة على خفض الحمل المعرفي وزيادة نسبة التحصيل الدراسي. وأثبتت دراسة Boucheix, Lowe بوشيكس، لو بوتري، وجروف فاعلية التلميحات Putri, and Groff, (2013) المكتوبة في القدرة على خفض الحمل المعرفي وزيادة نسبة التحصيل الدراسي. وأثبتت دراسة كيم، وجيلمان Kim, and Gilman (2008) المكتوبة في تنمية تعلم مفرادات اللغة الإنجليزية من خلال بيئة تعلم عبر الويب. وأثبتت دراسة نهى عبد

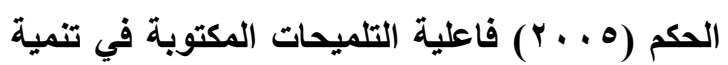
التحصيل الاراسي. 
يؤثر في التعلم. وينبغي استخدام الأنشطة التعليمية التي تسمح للمتعلمين بتناول المعلومات في سياق الموقف التعليمي، والعمل على تطبيق هذه المعلومات في سياقات متعددة؛ كي لا ينحصر تفكير المتعلم في الموقف المحدد، واستخدام استراتيجيات تعلم تحسن هذه السياقات المتعددة، للتأكد من أن المتعلمين يمكنهم بالفعل تطبيق المعلومات بشكل واسع، في مواقف عديدة (محمد عطية، II IY،

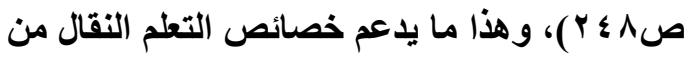
حيث التفاعل والتشارك، فالتعلم النقال يخلق بيئة تعلم جديدة، ومواقف تعليمية جديدة، تقوم على أساس التفاعل والتعلم التثاركي؛ والتكيف، فالتعلم النقال يقوم على أساس تكيفه مع حاجات المتعلمين. أيضًا يرتكز التعلم النقال على نظرية النشاط حيث أنها تركز على التعلم التعاوني والتثاركي، حيث يحدث البناء المعرفي ضمن مجتمع يتواصل به الأفراد مع بعضهم البعض، وبيئة أو نظام يسهم في مساعدة الأفراد على طرح تساؤلاتهم وتفسير آرائهم وعكس وجهات نظرهم، وأن نتائج التعلم الجماعي والتعاوني لا يقتصر فقط على الجاتب المعرفي، وأنما أيضًا على السلوك الاجتماعي لمكي (Zurit, \& Nussbaum, ودافعية المتعلمين للتعلم (2007, p.p. 209-222) وفي ضوء ما سبق فإن التعلم النقال يوفر للمتعلم الذي يريد أن يبني معارفه بنفسه من خلال البحث والاكتشاف والتلخيص والإطلاع الفرصة لذلك، وفي نفس الوقت تعطي
المحور الرابع: الأسس والمبادئ النظرية التي يقوم عليها البحث يساعد التعلم النقال على زيادة التفاعل بين الطلاب والمعلمين، والإدارة، والمجتمع، وهذا ما توفره النظرية البنائية التي تتيح للطلاب الإدراك والتفاعل، وتحقيق الاتصال المباشر مع الطلاب بما يتجاوز القيود الزمنية والمكانية ويتخطي الوجه التقليدي للتعليم (King, \& Gura, 2007)؛ لذلك فالتعلم النقال يرتكز على مبادى النظرية البنائية في عملية التعلم، حيث التمثيل الفردي للمعرفة من خلال الاستكشاف النشط، والمراقبة، والتجهيز، والتفسير، الذي يتيح للطلاب الانخراط بعمق مع المحتوى، وهذا من شأنه أن يوفر فرصة للطلاب ليس فقط في أن يكونوا نشطين في عملية التعلم ولكن يساعد أيضًا في إظهار معرفتهم وقدراتهم الخاصة (Lin, Kuo, Lin, Lin, Chang, ( \& Liu, 2012) لتوظيف التعلم النقال في العملية التعليمية حيث يتفق خصائص التعلم النقال مع توجيهات النظرية البنائية في أن للمتعلم الحرية في بناء مفهومه الخاص سواء أكان ذلك بشكل فردي أو من خلال التفاعل مع الآخرين للحكم على مدى أهمية وجدوى استخدامه لكل ما هو جديد (خالد فرجون، ص 9 ץ ( )، ويعد التعلم السياقي الموقفي من المجالات التي تركز عليها البنائية، ويعني أن التعلم هو عملية سياقية تحدث في سياق موقفي محدد؛ لأن السياق

المجلد الثامن و العثرون .... العدد الثانى ـ ابريل 1 1 ـ ץ 
الجمعية المصرية لتكنولوجيا التطليم

التعليميـة المكلفين بهـا، فالتلميحـات وفقَـا لنظريـة معالجة المعلومـات تعد معالجة لإثارة وجذب انتبـاه المــتعلم؛ ليتفاعـل مـــع موضــوعات الـتعلم، حتــى يستطيع اكتسـاب المعلومـات المطلوبـة في النهايـة. كمسا ترتكز التلميحـات على نظريـة الترميز الثنائي حيث ترتبط بنظريـة معالجـة المعلومــات المعرفيـة،

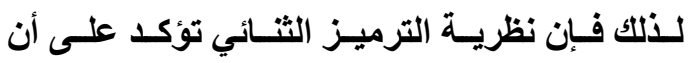
المعرفــة البشــرية تتكـون مـن نظــامين معـرفيين فرعيين يقومـان بمعالجة المعلومـات بشكل مستقل، ولكن متزامن، حيث توجد بينهمـا روابط وعلاقات تســح بـالترميز الثـائي للمعلومـات، فيوجد نـوعين مسن مسن وحـدات المعالجـة وهمـا: النظـام اللفظـي ويعالج المعلومات اللفظية ويقوم هذا النظام بتوليد الكلام للكائنات اللفظية، وتنظيمها في شكل ترابطات هرميــة؛ والنظــام البصــري ويعـالج المعلومــات المصوره، ويقوم هذا النظام بتوليد الصور العقلية وتنظيمها في شكل علاقات بين الجزء والكل (محمد

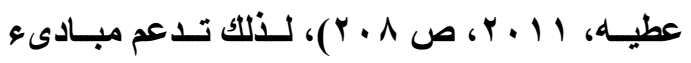
نظرية الترميز الثائي تقديم التلميحات إلى الطلاب،

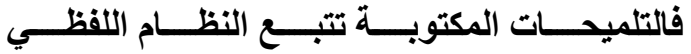
وخصائصسـه، أم التلميحسات اللونيــة تتبــع النظـــام

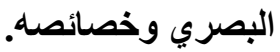

مما سبق حاول الباحثان الاستفادة من النظرية السلوكية والنظرية المعرفية في وضع الأهداف والمحتوى اللازم لإنتاج الإنفوجرافيك التعليمي الجيد وذلك لأن الطلاب لا يستطيعوا أن يبحثوا عن
للمتعلم الآخر الأي يحب التفاعل الإجتماعي مع الآخرين ويعتمد على الجو الإجتماعي أيضا نفس الفرصة، والسؤال الذي يطرح نفسه هنا مع أي متعلم تتجح بيئة التعلم النقال أكثر هل مع المتعلم المستقل الذي يحب أن يكون معارفه بنفسه؟، أم مع المتعلم المعتمد الأي يعتمد على التفاعلات الإجتماعية؟، هذا من جاتب ومن جانب آخر أيًا من نمط التلميحات الذي يقلم من خلال هذه البيئة سيفيد أكثر في تنمية التحصيل والأداء المهاري والتفكير الابتكاري للطلاب؟ وهذا ما يسعى البحث لاكتثافه بناعًا على المبادئ النظرية ومعرفة خصائص كل

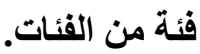

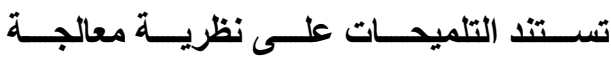
المعلومـات حيث تركز هذه النظريـه على العمليات التي يجريها الفرد لمعالجة المطلومات التي يستقبلها من العالم الخـارجي. وتقول أن العقل البشري يشبه الكمبيـوتر فـي تنــاول الرمـوز ومعالجتهـا، ولايـهـ مجموعة من الصور أو الرموز العقلية تثبه رموز الكمبيوتز الداخليه، فبإذا تطابقت الصور أو الرموز الخارجية للعالم الواقعي مـع الصور العقلية، يحدث المعنى، أي المعرفـة، والمعرفة هـي التعلم، ولكي تحدث هذه المعرفة توجد عمليات عقلية تحدث داخل الفـرد، لمطابقـة رمـوز العـالم الخـارجي مـع رمسوز الفـرد الاخليـة، وتوجد لهـا معنس (محمـد عطيـة،

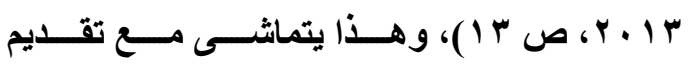
التلميحات للمتعلمين أثناء تعلمهـه أو تأديـة الأنثطة

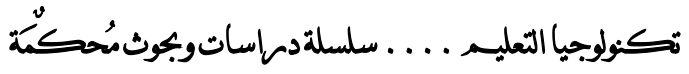


المتعددة، دعم تسليم الويب سهل الوصول لجميع أدوات التسليم، ووحدات التخزين القابلة للأستبدال؛ المجال الثاني تظوير المحتوى النقال ويهتم بالمعايير الأساسية للمحتوى النقال، وكذلك المعايير الخاصة بكائنات التعلم الرقمية، السلوك العام للويب النقال، الإبحار والوصلات، تخطيط الصفحات والمحتوى، تعريف الصفحة، مساهمة المستخدم؛ المجال الثالث دعم المحتوى الجوال ويهتم بتقديم المعايير الخاصة بإتاحة المحتوى، تحزيم المحتوى، البيانات الواصفة؛ والمجال الرابع تسليم المحتوى النقال ويهتم بخدمات الويب النقال، اتصال البيانات اللاسلكي، تكنولوجيالتعلم القريب/المكاني. ونظرًا لإستناد الباحثان على قائمة معايير تصميم بيئات التعلم النقال لزينب أمين، ووليد سالم عند تصميم بيئة البحث الحالي فقد تم الإعتماد فقط على المجال الأول أدوات المتعلم والمجال الثاني تطوير المحتوى النقال نظرًا لإرتباطهما ببيئة التعلم النقال في البحث

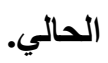

ومن خلال اطلاع الباحثان أيضًا على معايير تصميم المحتوى الإكتروني والمقررات والبيئات

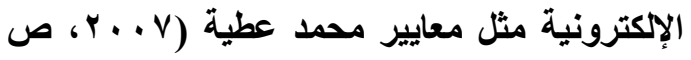

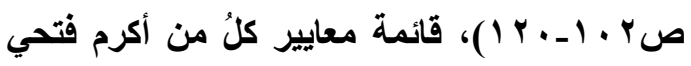

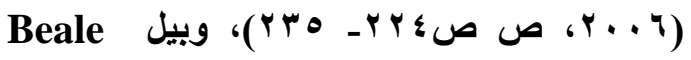
(2005)، وتنج (2010) Ting وهي المعايير التي لابد من مراعاتهما عند تصميم البيئات الإلكترونية،

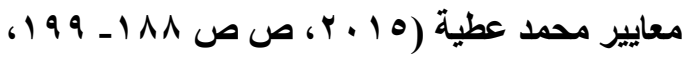

المحتوى بذاتهم لكنهم يقوموا بالبحث عن تنفيذ الأنثطة والتكليفات أو مهمات التعلم التي يعطيها المعلم لهم بثكل جماعي محققًا بذلك مبادئ النظرية البنائية والبنائية الإجتماعية، والتعلم النشط والموقفي. المحور الخامس: معاييز تصميم بيئة التعلم النقال في ضوء نمط التلميحات (المكتوبة/ اللونية) من خلال العرض السابق للاراسات والبحوث التي تناولت بيئات التعلم النقال وأيضًا الاراسات التي تناولت التلميحات سواء المقدمة من خلال بيئات التعلم النقال أو التعلم عبر الويب بصفة عامة، فوجد الباحثان أن كل من زينب أمين (0 ا ـ Y، ص

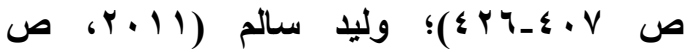

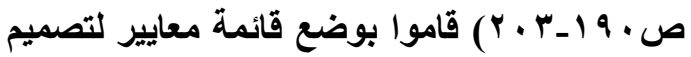
بيئات التعلم النقال، ولذلك اعتمدا عليها الباحثان عند تصميم بيئة التعلم النقال في البحث الحالي، ولكن بعد إجراء التعديلات المناسبة حتى تصلح مع الإستراتيجية التعليمية المتبعة في البحث الحالي وقائمة المعايير تتكون من أربعة مجالات رئيسبة وكل مجال يشتمل على مجموعة من المعايير، وكل معيار يشتمل على مجموعة من المؤشرات التي تحققه وهي: المجال الأول أدوات المتعلم ويهتم هذا المجال بمواصفات أدوات التسليم كالهواتف النقالة، المساعدات الرقمية الثخصية، أجهزة الكمبيوتر المحمول، مشغلات الصوت، مشغلات الوسائط 
الجمعية المصرية لتكنولوجيا التعليم

المعرفية أيضًا لتضم عديد من التصنيفات، وعند قيام المعلم بمعرفة أسلوب تعلم طلابه وطريقة معالجتهم للمطلومات يساعده ذلك على اختيار طرق وإستراتيجيات التدريس التي تتفق مع أساليب تعلم طلابه، مما يؤدي إلى زيادة تحصيلهم الدراسي وقدرتهم على التفكير وفي البحث الحالي يتم التركيز على أسلوبي الإعتماد مقابل الإستقلال عن المجال

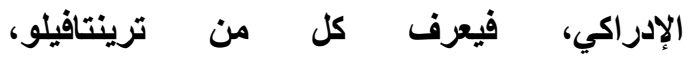
بومبورتيسيس، ديمترياديس، \& \& Traintafillou, Pomportsis, Demetriadis, \& Georgiadou (2004, p.96) بأنه يعتبر مدخل الفرد المفضل والمعتاد نحو تجهيز وتنظيم ومعالجة المطومات والمثيرات في البيئة المحيطة، كما أنه يعبر عن نماذج السلوك التي تصف كيفية تعلم الفرد، وأبعاد الشخصية التي تؤثر على الاتجاهات والقيم والتفاعلات الاجتماعية، ولكن تبنى الباحثان تعريف أنور الثرقاوي

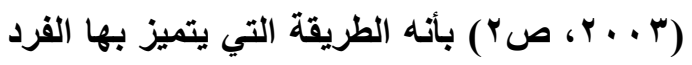
أثثاء معالجته للموضوعات المختلفة التي يتعرض لها في مواقف الحياة اليومية مما يجعله خاصية لثخصية تظهر في نماذج سلوكه الإدراكية والعقلية.

للأساليب المعرفيه خصائص هي: أنها تتعلق بشكل النشاط المعرفي للإنسان وليس محتواه؛ يتصف بالثبات النسبي وهو ينمو ويصبح أكثر تمايزًا لاى الإنسان مع الوقت والخبرة؛ تعد أبعادًا

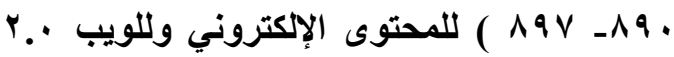
وأدواته، ومعايير محمد عطية (10 بץ، ص

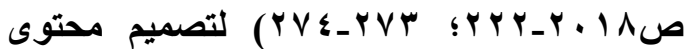
التعلم النقال؛ ومعايير تقويم واختيار الجهاز النقال، وأيضًا معايير إتحاد الويب العالمي World Wide لتصميم (Web Consortium "W3C") المحتوى الإكتروني في صورة مبادرة سميت باسم معايير مبادرة إتاحة الويب (Web) Accessibility Initiative "WAI" هذه المبادرة أربعة معايير رئيسية واشتمل كل معيار على مجموعة من المؤشرات، وقام الباحثان بإعداد قائمة معايير لتصميم بيئة النقال وفقَّا لنمط التلميحات حيث تضمنت هذه القائمة با معيارًا رئيسًا هي: أدوات المتعلم، تطوير المحتوى النقال، الأهداف التعليمية، المحتوى التعليمي، الأنثطة التعليمية، استراتيجيات التعليم والتعلم، التغذية الراجعة، التقويم، التلميحات (المكتوبة؛ واللونية)، واجهة التفاعل، التفاعلية والتحكم التعليمي، سهولة الاستخدام، الوسائط المتعددة وتضم: النصوص؛ الصور؛ الفيديو؛ الرسوم المتحركة؛ والصوت. المحور السادس: الأسلوب المعرفي تعريف الأسلوب المعرفي وخصائصه: نظرًا لتنوع خصائص المتعلمين واختلافها فيما بينهم فكل متعلم يفضل أسلوب تعلم معين وطريقة محدده تختلف عن غيره وتتنوع الأساليب

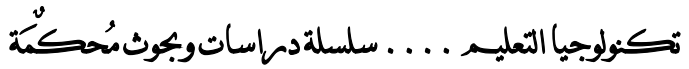


قدرة الفرد على التعامل مـع الموضوعات كعناصر إدراكية في المجـال، في اعتمـاده على المجال وفي استقلاله عنـه. ويقصد بـالفرد المعتمد على المجـال ذلك الفرد الذي لا يستطيع إدراك موضـوع إلا في تنظيم شامل كلي للمجال بحيث تظل أجزاء الأرضية بالنسبة لـه غير واضـحة، أمـا الفرد المستقل عن المجـال ذلـك الفرد الذي يستطيع إدرالك الموضـوع

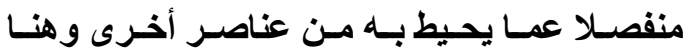
يستطيع أن يحلل المجال المركب (حمدي الفرمساوي،

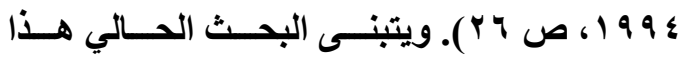
التعريف نظرًا لشموله ووضوحه.

ذكرت كثيرًا مـن الأدبيـات خصـائص الأسلـوب المعرفي الاعتمــاد مقابل الاستقلال ولكن الباحثـان اقتصر ا على الخصائص التي حددها هشـام الخولي

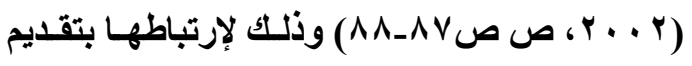
التلميحـــات للمتعلمــين، فالأســلـوب الاعتمـــادي خصائصسه هـي: يــــم بيئـات الـتعلم الاجتماعيـة، يفضـلون توجيـه إسـتراتيجيات قبـل توجيـه التـطلم،

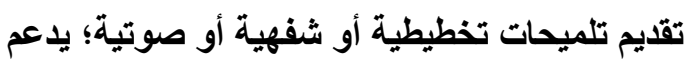

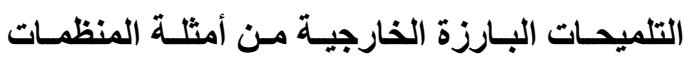
المتقدمة؛ لهم اتجاهـات صريحة ويفضلون الإرشـاد ويتظوقون دائمًا للمسـاعدة؛ يفضلون تغذيـة راجعـة واسـعة وخاصـة المثققــون مـنهم؛ ملائمسة المـنظم المتقدم مـع تلك الصفة (منظم لفظي أو شفهي أو مصور)؛ وضع نقاط أساسية للمحتوى الاراسي أو

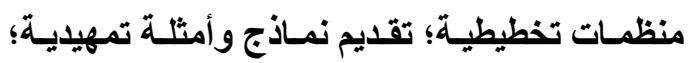
الاحتيـاج إلـى دعـم تعليمسي للمتعلمـين على شـكل
ثنائية القطب ويصنف الأفراد وفق ذلك على متصل يبدأ ببعد ما وينتهي ببعد آخر، وهذا يعني أن التصنيف يأخذ شكل المنحنى الإعتدالي بالنسبة ولية للأسلوب الواحد. ورغم أن الأسلوب المعرفي ثنائي القطب إلا أن لكل قطب قيمته وأهميته في ظل شروط معينة ترتبط بالموقف؛ لا تختصر الأساليب

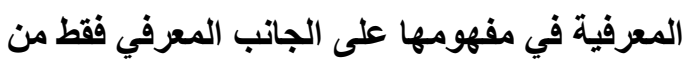
الثخصية ولكنها تعتبر مؤشرًا هاما في النظر إلى لى الثخصية نظرة كلية تتضمن جميع أبعادها، ولعل هذا يجعل الباحثين ينظرون إلى هذه الأساليب كأبعاد مستعرضة للثخصية؛ تقاس بوسائل لفظية وغير لفظية، مما يساعد على التظلب على كثير من الصعوبات التي تنشأ عن اختلاف المستويات الثقافية للمتعلمين (أنور الثرقاوي وسليمان الثيخ، 9111، ص ص بـ؛؛؛ أنور الثرقاوي،

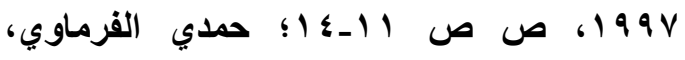

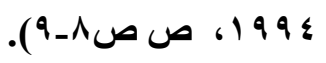
الأســلوب المعرفــي الاعتمـــاد مقابـل الاســتقلال وخصائصه: نظـرًا لتعـدد تصــنيفات الأســاليب المعرفيـة، فيقتصر البحث الحسالي على أسلوب الإعتمـاد مقابل الإسـتقلال لملائمــة البيئـة الحاليـة لهـذان النوعـان بالـــات حيــث أنهـــا تتميـز بصــفة الشخصــية والإجتماعيـة لمعرفـة مـدى ملائمتهــا أكثـر لنـوع وخصسائص المتعلمسين، فيشـير الأسـلوب المعرفي المعتمد والمستقل كما حدده وتكن وزملاؤه إلى مدى 
الجمعية المصرية لتكنولوجيا التعليم

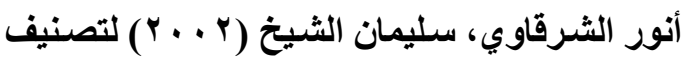

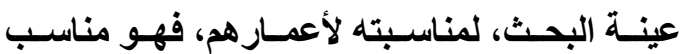
لقيـاس الفـروق الفرديـة بـين الطـلاب والمـراهقين والكبـار والمسـنين، ولسـهولة تطبيقهـ فهو اختبـار ورقـة وقّلم، ولا يحتـاج إلى موقف تجريبـي، وهو أكثر الاختبارات استخدامًا وشيوعًا، كما أثبتت عديا من البحوث والدراسات السـابقة مدى صدقة وثباتـه

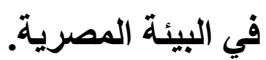
المحور السابع: التفكير الابتكاري ـ تعريف التفكير الابتكاري: للتفكير الابتكاري عديد من التعريفات فيعرفها

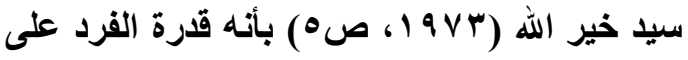
الإتتاج إنتاجًا يتميز بأكبر قدر من الطلاقة الفكرية والمرونة التلقائية والأصاية بالتداعيات البعيدة كإستجابة لمشكلة أو موقف مثير. ويعرفه خليل معوض (99019، ص99 ؛) بأنه القدرة على تعداد الاستجابات عندما يكون هناك مؤثر، أو هو نوع من التفكير الجديد والتامل والاختراع أو الإتيان بحل Gehlbach (1987. طريف، وعرفه ايضًا جيلباخ p. 13) بأنه إيجاد الحلول الممكنة لمشكلة لم يسبق . مواجهتهامن قبل، ولكن البحث الحالي تبنى نعريف

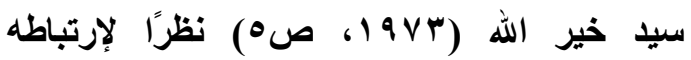
بالسياق التعليمي المراد تعلمه الطلاب. مهارات التفكير الابتكاري: يتضح من التعريفات المختلفة للتفكير الابتكاري أنـه

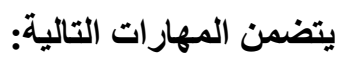

(أمثلــة، أدوات، مراجع)؛ تضـمين أسئلة مسن خـلال تقديم التعليم؛ الاهتمـام بالأسـلوب الاستنتتاجي في مي تنظيم المحتـوى وكــللك تقـــيم تتابعـات إجرائيـة تعليمية. بينما الأسلوب الاستقلالي خصائصسه هي: تقديم بيـــة تعليميـة مسـتقلة (فرديـة)، تقديم طرق تعليميـة قائمسة على الاسـتعلام والاكتثــاف، تقديم مراجـع ومصسادر تعليميـة غزيـرة ومصسنفة، تقديم أسـاليب الـتعلم الـذاتي، تضــمين إرشــادات بسـيطة وليست أساسية، سؤال المتعلمين عن طرح الأسئلة التي قاموا بالإجابة عليها، استخدام تتابعات تعليمية اسـتقرائية، تضـمين رسـومات تخطيطيـة وخـرائط للمفــاهيم، اســتخدام تتابعــات النظريــة التوســية

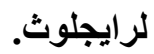

قيساس الأسـلوب المعرفي الاعتمـاد مقابل الاستقلال

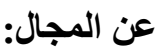
يوجــ الكثير مسن اختبـارات قيساس الأسـلوب المعرفي الاعتمـاد مقابـل الاستقلال فمنهـا: اختبـار المؤشر والإطار؛ اختبار تعديل وضع الجسم؛ اختبار الأشكال المتضمنة؛ اختبار الغرفة الدوارة؛ اختبار الأثكال المتذاخلة؛ اختبار الأشكال المختفية، ولكن البحث الحالي استتدا على اختبار الأثكال المتضمنة Group Embedded في صورته الجمعيـة Figure Test (GEFT) وزملاءه (1977) Witkin etal و وقام بترجمتة وتعريبه وتقتيته أنـور الثـرقاوي، سليمان الثـيخ (911 (1 ) وتمت إعادة طباعته حتى الطبعة الخامسة

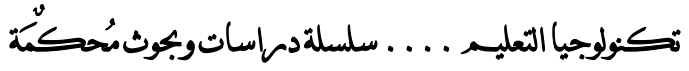


ويضـع تخمينـات للحل ويصيخ فروض ثم

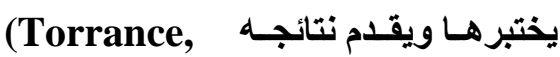
.1979, p. 144) هـ التفصيلات: وهي قدرة الفرد على تطوير فكرتـه وتحسينها بإضسافة تفصيلات إليها وإيضـاحات تســاعد عـى إبـراز فكرتــه الأصيلة (عبد الله سليمان، فؤاد أبو حطب،

$$
\text { (1) (1) (19v. }
$$

דـ الاحتفاظ بالاتجاه: وهي قدرة الفرد على

التركيز المصحوب باتتباه طويل الأمد، على هاف معين وتخطي أي مشتتات، والالتفاف

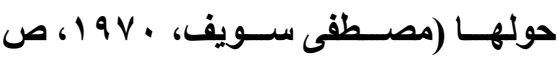
.$(r 99$

Vـ القدرة علـى التقـويم: وهـي تقوم على اتخـاذ معيـار أو محك، ثم التأكد من اتفـات

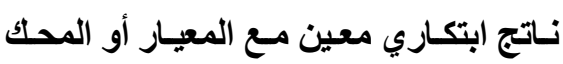

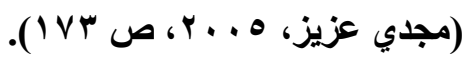

اختبار التفكير الابتكاري:

توجد عديد من اختبارات التفكير الابتكاري التي

اطلــع عليهـــا الباحثـــان منهــــا اختبــار تــورانس Torrance (1962) سليمان، فؤاد أبو حطب، • V V ( )، واختبـار القدرة على التفكيـر الابتكـــــ الـذى أعـده (سـيد خيـر

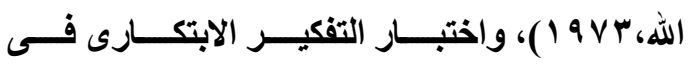

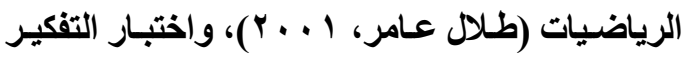
الابتكـارى فى التطبيقـات التطليميـة للإنترنت (أسـامه
1ـ الطلاقة: وهي القدرة على استدعاء أكبر قدر ممكن من الأفكار الابتكاريـة في مدة محدودة، وبالتـالي فالطالب المبتكر يتميز بسـهولة وسـرعة وكميـة إنتــاج الأفكـار، والتي يمكن أن يقترحها بالنسبة لموضوع

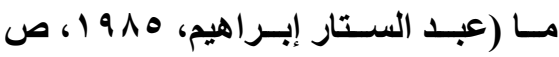

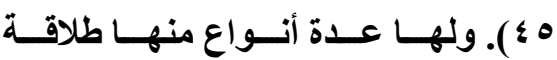
الأثــكال، الرمـــوز، التــــاعي، الطلاقِـــة الفكريــة، والتعبيريــة (يوسـف قطــامي،

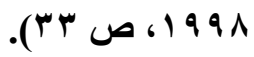
r- المرونة: وهي قدرة الفرد على أن يعطي تلقائيا عددًا متتوعا من الاستجابات، التي لا تنتمسي إلى فئسة واحدة، بمعنى أن يكون الإبـاع في أكثر مـن مشـكلة (شـاكر عبد الحميد، 999 19، ص س آץ). ولثها نوعان همـا المرونـة التلقائية، والمرونـة التكيفيـة (مجدي عزيز، ه . . T، ص M IV ). rــ الأصالة: وهي تجمـع بين مظاهر سلوكية تتبلور في القرة على إعطاء أفكار أصيلة أو ينظر إليها على أنها نفور من تكرار مـا يفعله الآخرين أو يفكرون فيه، أو أنها تدل على إدراك الفرد للأثياء في صورة جديدة غير مألوفة أو إدراك علاقات نـادرة جديدة أو إنتاج أفكار طريفة. ءـ الإحسـاس بالمشكلة: وهي قدرة الفرد على اكتثـاف أوجـه النقص فيحدد السبب

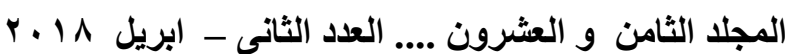


الجمعية المصرية لتكنولوجيا التعليم

واعتمادية المجال تصف الدرجة التي يتفاعل بها المتعلمون مع العرض، سواء كان المتعلم سيتفاعل مع المحتوى كما هو أم سيقوم بالتحليل وإعادة التنظيم والبناء للمجال التعليمي لجعل المحتوى أكثر معنى وقابلَّا للتذكير، وهذا يؤكد على أهمية التفاعل بين التلميحات والأسلوب المعرفي. حيث هدفت دراسة ياتج (2016) Yang التعرف على أثر التفاعل بين أربعة أنماط من التلميحات هي: بلون تلميحات؛ التلميحات الثابتة؛ التلميحات الثابتة مع اللونية؛ والتلميحات المتحركة مع الأسلوب المعرفي البصري مقابل اللفظي، فتوصلت نتائج الدراسة أن التلميحات جميعها عملت على خفض الحمل المعرفي وتركيز الانتباه وزيادة التحصيل الدراسي لكل من الأسلوب المعرفي البصري واللفظي مما يذل على عدم وجود تفاعل. ولكن توصلت نتائج إيمان

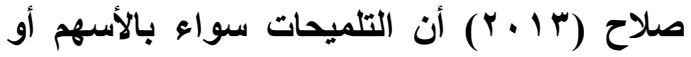
اللون عملت على تنمية التحصيل المعرفي والأداء المهاري وسهولة الاستخدام بشكل أكبر لاى الطلاب المعتمدون، عكس الطلاب المستقلون فمستواهم لم يتغير وهذا يثبت أن يوجد تفاعل بين التلميحات والأسلوب المعرفي لصالح المعتمدون. وأثبتت

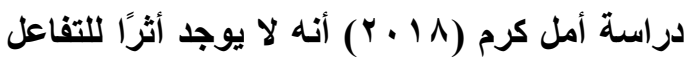
بين الدعم التعليمي القائم على نمطي التلميحات الملونة والشارحة بيئة التعلم الإلكتروني وأسلوب التعلم السطحي والعميق، وكلا النمطين مع أسلوب التعلم ساعدا في تنمية ممارسة الأنشطة

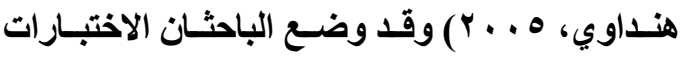
السـابقة موضـع الاعتبـار عند بنـائهم لاختبار التفكير الابتكارى الخاص بالبحث الحالي.

المحور الثامن: العلاقة بين نمطي التلميحات والأسلوب المعرفي وتنمية المهارات يعد الأسلوب المعرفي الاعتماد والاستقلال عن المجال بمثابة إنعكاس للمدى الأي يتعامل فيه المتعلم مع المعلومات والمعارف المقدمة إليه وأيضًا أساليب المساعدة ومنها التلميحات، حيث تصف الكيفية التي يتفاعل بها مع المحتوى المراد تعلمه، ومن ثم تحدد الطريقة أو النمط الذي سيتعلم به المتعلم، ويتضح من خصائص المعتمدون والمستقلون، فالأفراد المعتمدون على المجال الإدراكي يعتمدون بثكل رئيسي على التلميحات الخارجية ويتقبلون أثكال التمثيل الرمزي والإدراكي كما هي بدون إعادة تنظيم، بخلاف الأفراد المستقلون عن المجال الإدراكي يعتمدون على التلميحات الداخلية بلرجة كبيرة، وذلك بغرض (Tinajero, فرض التظيم على المعلومة المتلقاة (أكلات \& Paramo, 1997, p.87)

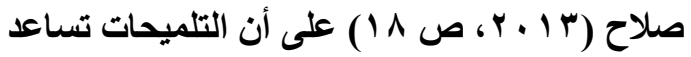
المتعلمين على تنظيم أو تصنيف المعلومات المقدمة داخل أنماط مفيده كما أنها تستخدم لتركيز الانتباه على المعلومة أو الجزء موضع الاهتمام داخل المجال المرئي المعروض بهذف منع أي تحريف في الإدراك بالذاكرة، والسلسلة المتصلة من استقلالية

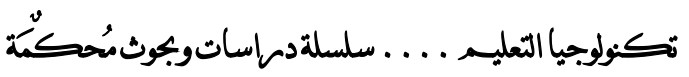


للأسلوب المعرفي على التحصيل لصالح الطلاب المستقلين، ووجود تأثير أساسي للأسلوب المعرفي على مهارات التعلم الذاتي لصالح الطلاب المعتمدين، بينما لا يوجد تأثير أساسي للأسلوب

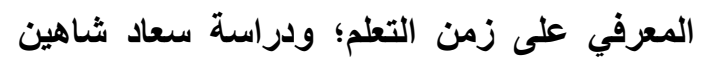
كثفت عن وجود تأثير أساسي بين (Y..V) التخص الأكاديمي والأسلوب المعرفي لصالح الطلاب المعلمين المستقلين، وعدم وجود أثر

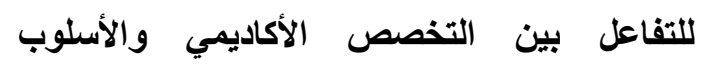
المعرفي في تصميم و إنتاج ملف الإنجاز الإكتروني؛

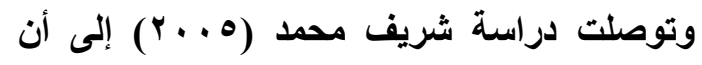

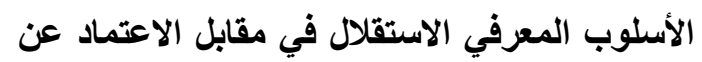
المجال الإدراكي له أثر دال إحصائيًا على تحصيل

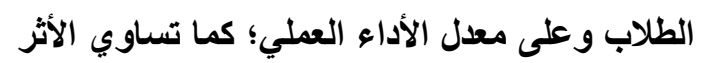
في التحصيل المعرفي بين الطلاب المستقلين و والمعتمدين.

في ضوء ما سبق وجد الباحثان أن البحوث والدراسات تناولت أثر التفاعل بين التلميحات ومتغيرات أخرى مع الأسلوب المعرفي مع بيئات أخرى غير بيئة البحث الحالي، ولكن أوصت هذه

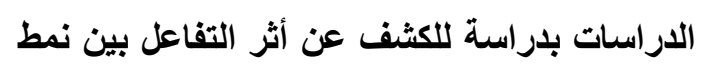
التلميحات والأساليب المعرفية. لذلك فإن هذه الاراسات لم تبحث في التوصل إلى أثر التفاعل بين نمط التلميحات (المكتوبة/اللونية) مع الأسلوب المعرفي الاعتماد مقابل الاستقلال عن المجال في التعلم النقال على تنمية التحصيل ومهارات إنتاج الإنفوجرافيك الثابت التعليمي والتفكير الابتكاري
الإكترونية، وكفاءة التعلم، ومهارات التفكير فوق المعرفي لاى طلاب تكنولوجيا التعليم. أيضًا تناولت عديد من الاراسات والبحوث العلاقة بين الأسلوب المعرفي الاعتماد في مقابل الاستقلال عن المجال الإدراكي والتحصيل المعرفي لهي والأداء المهاري ومنها: دراسة أحمد فهيم

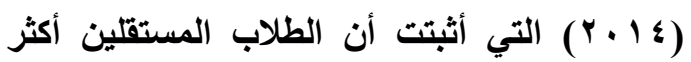
تقدمًا في تحصيلهم الدراسي وتنمية تفكير هم العلمي عن الطلاب المعتمدين؛ ودراسة عصام شوقي

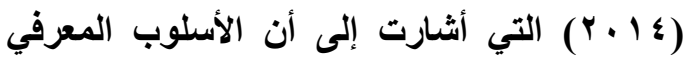

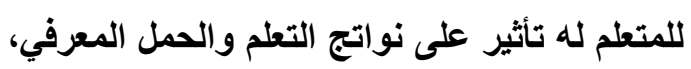
حيث أن الطلاب المستقلين أكثر تفوقا من المعتمدين في اختبار نواتج التعلم ومقياس الحمل المعرفي؛

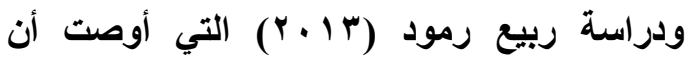
للأسلوب المعرفي له أثرًا فعائًا على تنمية الأداء المهاري للطلاب المستقلين عن المعتمدين، بينما لا يوجد أثرًا له على كل من المستقلين والمعتمدين فكان تأثيره متساوي في تنمية التحصيل الدراسي؛

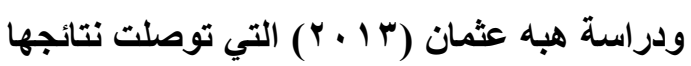
إلى أن الأسلوب المعرفي الإعتماد في مقابل الاستقلال ساعدا بشكل متساوي في تنمية التحصيل المعرفي والأداء المهاري؛ ودراسة أميرة المعتصم

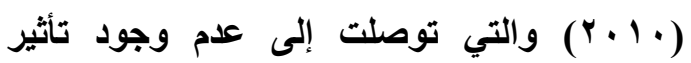
أساسي للأسلوب المعرفي الاستقلال في مقابل الاعتماد عن المجال الإدراكي على تنمية التحصيل، زمن التعلم، والقابلية للاستخدام؛ ودراسة زينب

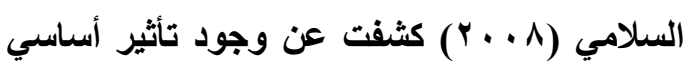


الجمعية المصرية لتكنولوجيا التعليم

\section{الطريقة والإجراءات}

أولا: تحديــ معـايير تصـميم بيئـة التعلم النقـال في ضوء نمط التلميحات (المكتوبة/ اللونية):

لما كان البحث الحالي يهدف إلى الكشف عن

أثتـر التفاعـل بـين التلميحــات (المكتوبة/اللونيــة) والأسـلوب المعرفـي في الـتعلم النقــال على تنميـة مهارات إنتاج الإنفوجر افيك والتفكير الابتكاري للى طلاب تكنولوجيـا التعليم، لذلك تتطلب الأمـر تحديـ معسيير تصــميم بيئـة الـتـلم النقــال وفقــا لـنمط التلميحــات، ولتحديــــ المعــيير قـــام الباحثـــان

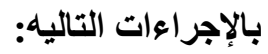

1. مسـح الأدبيات والاراسـات والبحوث المرتبطة بـالتعلم النقال و التلميحات ومبادئهـا ونظرياتها المشــار إليهـا في البحثث الحسلى، وأيضًا مـن خـلال اطـلاع الباحثــان علــ مجموعـة مـن المعايير المرتبطة بتصميم بيئات التطلم وخاصـة عبر الويب كما ورد بالإطار النظري للبحث. r. استخلاص قائمسة معايير مبائيسة لتصـيم بيئة التعلم النقـال وفقـا لنمط التلميحـات في ضوء قائمـة معايير تصميم بيئة التعلم النقال لزينب

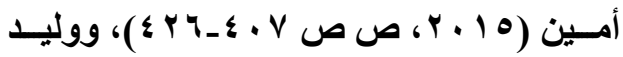

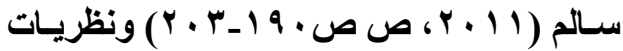
الـتطم المختلفـة التــي أوضـحها الباحثـــان فـي الإطار النظري للبحث وكان عدد المعايير بان

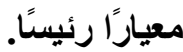

لاى طلاب تكنولوجيا التعليم، ومن هنا كانت الحاجة إلى دراسة أثر التفاعل بين نمط التلميحات

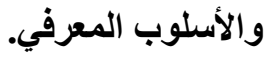

مما سبق يتوقع الباحثان في البحث الحالي حدوث تفاعل بين نمط التلميحات (المكتوبة/اللونية) الأسلوب المعرفي (المعتمد/المستقل) في التعلم النقال بدلاية التحصيل المعرفي، تنمية مهارات الإنفوجرافيك، التفكير الابتكاري لاى طلاب تكنولوجيا التعليم. المحور التاسع: نموذج التصميم التعليمي المستخدم في البحث الحالي تعددت نماذج التصميم التعليمي لبيئات التعلم الإكتروني بصفه عامة التي تعتمد على نظريات التعليم والتعلم المختلفة إلا أن الباحثان تبنى نموذج

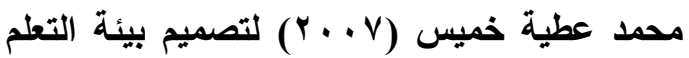
النقال في البحث الحالي وذلك لأنه نموذج مرن، شمولي، مناسبة النموذج لطبيعة التعلم النقال، يدعم النموذج التكامل والامج بين النظرية السلوكية، المعرفية، والبنائية، ويهتم بأنماط التعليم المختلفة (الفردي، الجماعي، الجماهيري)، يمكن تطويره ليناسب بيئات التطلم الإلكتروني المختلفة. وهذا ما سيتم عرض مراحل النموذج عند تصميم مادة المعالجة التجريبية في جزء الطريقة والإجراءات. 
متبعًا نمـوذج محمد عطيـة خمسيس ويتضـمن أربـع مراحـل (التحليـل، التصــميم، التطــوير، التقــويم

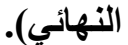

المرحلـة الأولـــى: التحليـلِ: ويتضـمن التحليـل

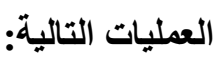

اـ تحليـل المشـكلات وتقدير الحاجـات: تـم تحديــ المشكلة في مقدمة البحث وكيفية ظهورها من خلال تحليل الباحثان للاراسات السابقة وتوصيات البحوث بشـأن الاهتمـام بتحديـــا أفضـلية التفاعل بـين نمـط التلميحـات (المكتوبة/اللونيـة) والأسـلوب المعرفـي (المستقل/المعتمد) في البيئـات الإكترونيـة وخاصـة في التعلم النقال، ومن خلال إجراء الباحثان للاراسة الإستكشافية للوقوف على حاجات الطلاب في مقرر إنتاج الرسومات التعليمية بالفرقة الثانية تخصص تكنولوجيـا التعـيم وتحديـاًا المعسـارف والمهـارات

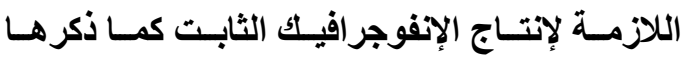
الباحثان مسبقًا وتحديد المشكلات التي تقابلهم في إنتاجها لكي يقوم الباحثان بمعرفتها. وتتضمن هذه الخطوة النقاط التالية:

1 ـ 1 ) تحديد الأداء المثالي أو المطلوب: حدد الباحثان الأداء المثالي بعد إطلاعهم على مقرر الكلية وهو مقرر إنتاج الرسوم التعليمية للقرقة الثانية تخصص تكنولوجيا التعليم بكلية التربية النوعية جامعة المنوفية للتوصل إلى قائمة بالأهداف العامة المثالية وهي كالتالي: (التعرف على ماهية r. قــام الباحثـان بعـرض قائمــة المعـايير عـى مجموعة من المحكمين من المتخصصين في تكنولوجيـا التعلـيم وعـدهم خمسـة، وإجـراء التعـديلات فــي ضـوء الملاحظــات وتوصـل الباحثــان إلـي قائمسة المعسيير فـي صـورتها

$$
\text { النهائية بملحق (0). }
$$

حيث تكونـت قائمسة معايير تصـميم بيئة التعلم النقال وفقَا لنمط التلميحات من ب ا معيارًا رئيسًا ومجموعة من المؤشرات التي تحقق هذه المعايير و المعسيير الأساسـية هـي: أدوات المـعلم، تطوير المحتـوى النقــال، الأهــافـ التعليميـة، المحتـوى التعليمي، الأنثطة التعليمية، استراتيجيات التعليم والـتـعلم، التغذيــة الراجعـة، التقـويم، التلميحـات (المكتوبـة؛ واللونيـة)، واجهـة التفاعل، التفاعليـة والـتحكم التعليمس،، سـهولة الاســذام، الوســائط المتعـدة وتضــم: النصـوص؛ الصــور؛ الفيــيو؛ الرسوم المتحركة؛ والصوت. ثانيا: تصميم بيئة التعلم النقال وتطويرها في ضوء

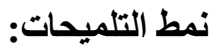

تبنى الباحثان نموذج محمد عطية خميس (Y . . V V) ليستقبل جميع أنواع البيئـات التعليميـة الالكترونيـة عبر الويب والوسـائط المتعددة، وإمكانيـة تطويره. وفيمـا يلي مراحل تصميم مـادة المعالجـة التجريبيـة وهـي "بيئـة التـطم النقـال وفقـا لـنمط التلميحـات 
الجمعية المصرية لتكنولوجيا التعليم

1 - ) صياغة قائمة بالحاجات التطليمية مرتبة حسب الأهمية وذلك على النحو التالي:

- التعرف على ماهية الإنفوجرافيك الثابت.

- - التعرف على المهارات العامة لإنتاج الإنفوجر افيك الثابت.

- التعامل مع بيئة العمل بيرنامج الفوتوشوب.

- التعامل مع الأدوات الأساسية داخل

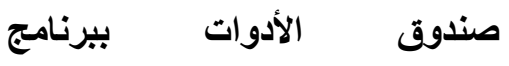
الفوتوشوب.

- التعرف على وظيفة اللوحات داخل برنامج الفوتوشوب.

- - استخدام أدوات التحديد داخل برنامج

$$
\text { الفوتوشوب. }
$$

- التعامل مع الرسوم داخل برنامج

$$
\text { الفوتوشوب. }
$$

- التعامـل مـع النصـوص داخل برنـامـج

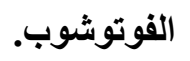

ـ ــايد طبيعة المشكلة: وقد تم تحديد طبيعة المشكلة في بداية البحث والاشارة إليها في باية مرحلة التحليل وهي مشكلة تعليمية تصميمية.
الإنفوجرافيك الثابت، التعرف على المهارات العامة لإنتاج الإنفوجرافيك الثابت، التعامل مع بيئة العمل بيرنامج الفوتوشوب، التعامل مع الأدوات الأساسية داخل صندوق الأدوات ببرنامج الفوتوشوب، التعرف على وظيفة اللوحات داخل برنامج الفوتوشوب، استخدام أدوات التحديد داخل برنامج الفوتوشوب، التعامل مع الرسوم داخل برنامج الفوتوشوب، التعامل مع النصوص داخل برنامج

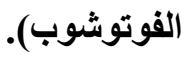

(Y-1) قياس المستوى الفعلي للأداء الواقعي الحالي وتحديده: تم قياس المستوى الفعلي للأداء من خلال إجراء اختبار وتقييم مهارات الإنتاج للإنفوجرافيك الثابت للطلاب الذين دَرس لهم المقرر بالثكل التقليدي، وتوصل إلى أنه يوجد نقص لاى الطلاب فيما يخص الإجابة على الاختبار المقدم لهم الخاص بمقرر إنتاج الرسوم التعليمية فيما يخص الإنفوجرافيك الثابت وأيضًا ضعف في قراتهم على إنى الإنتاج والتوظيف للإنفوجرافيك الثابت في التعليم، وكذلك مستوى معرفتهم لهذه الأهداف منخفضة.

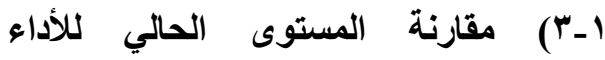
بالمستوى المثالي لله، وتحليد حجم الفجوة والإحرافات بينهما: تم تحديد ذلك بناءًا على نتائج الاختبار الذي تم إجراءه على طلاب تكنولوجيا التعليم والأي تبين منه حجم الفجوة بين الأداء المثالي والأداء الحالي مما أظهر انخفاض مستوى الأداء

$$
\text { الفعلي عن المثالي. }
$$

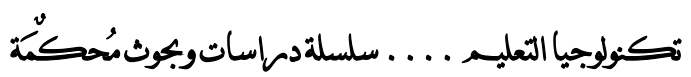


- - المهمـة الأولى: التعرف على ماهيـة الإنفوجر افيك الثابت.

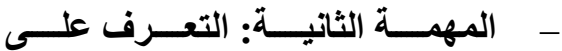

المهارات العامـة لإنتاج الإنفوجرافيك الثثابث.

- - المهمة الثالثة: التعامل مع بيئة العمـل ببرنامج الفوتوشوب.

- المهمـة الرابعـة: التعامـل مـع الأدوات

الأسـاســية داخـلـ صــندوق الأدوات

$$
\text { ببرنامج الفوتوشوب. }
$$

- - المهمة الخامسة: التعرف على وظيفة

اللوحات داخل برنـامج الفوتوشوب.

- ـ المهمــة السـادســة: اســتخدام أدوات

التحديد داخل برنامج الفوتوشوب.

- - المهمة السـابعة: التعامـل مـع الرسـوم داخل برنامج الفوتوشوب.

- المهمة الثامنة: التعامل مع النصوص

$$
\text { داخل برنامج الفوتوشوب. }
$$

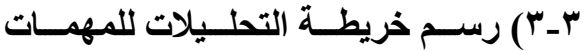

الرئيسية والفرعية: حيث تم رسم لخريطة المهمـات

التي تم التوصل إليها في الخطوات السـابقة، بملحق

بـ ـ ) تحديد المتطلبـات السـابقة للتعلم على

خريطة التحليل: وذلك برسم خط يفصل بين التعلم
Y ـ اختيــار الحلــول القائمــة علــى الكمبيــوتر أو الإنترنت: بعد إجراء عملية تحليل المشكلة وتحديدها في شكل أهداف عامة، تم اختيار الحلول القائمـة على الكمبيوتز وتحديد نوعيـة برنـامج الكمبيوتر التعليمي المناسب لحل هذه المشكلات، والبرنامج المناسب هنـا هو بيئة التعلم النقال لأن معظم حاجـات الطالب تعتمد على جـزء التواصـل والمشـاركة والتبـادل واحتيـاج الآراء والتعليقهـات واحتيــاج المســاعدة مــن المعلـم وتوجيهاته على حسب حاجته، ولذلك حاول الباحثان تصميم بيئة التعلم النقال لمحاولة التظلب على حاجـات الطظلاب.

rـ تحليل المهمات التعليمية أو المحتوى التعليمي: بالإعتمـاد على مقرر إنتاج الرسوم التعليميـة للفرقة الثانية تكنولوجيا التعليم كما في النقاط التالية: بـ 1) تحديـ المفـاهيم والمهـار ات من خـلال التحليـل الهرمسي القهقري مـن أعلـى إلـى أسـلف، وتحليـل الغايـات والأهداف العامـة للمحتوى العلمـي إلى أهداف نهائية وممكنة.

r-r) إجـراء التعـديلات اللازمـة والوصـول إلى التحليل النهائي وكـان الهـف العـام هو التعرف على بعض معسارف ومهارات إنتاج الإنفوجر افيـك الثابت ببرنـامج الفوتوشـوب وتوظيفهـا في العملية التعليميـة وإنـــرج تحتهـا بعض المهـــات القرعيـة وعددها سبع مهمات كالتالي:

المجلا الثامن و العشرون .... العدد الثانى ـ ابريل 1 1 . r 
الجمعية المصرية لتكنولوجيا التعليم

بخبرة التعلم من خلال بيئة التعلم النقال، وللتوصل

إلى تصميم الأهداف تم المرور بالخطوات التالية:

1 ـ 1 ) تحديـــ الهـدف العـام مـن تصـميم بيــة

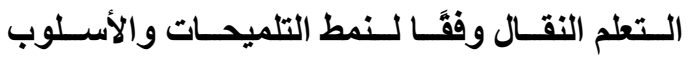

المعرفي وهـو هنـا "التعرف على بعض معسارف

ومهــار ات إنتــاج الإنفوجرافيــك الثابــت التعليمسي

بإستخدام برنامج الفوتوشـوب وتوظيفهـ في العملية

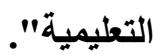

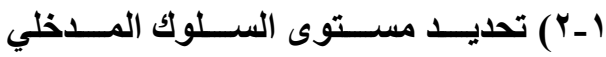

للطـلاب: وقـد تـم ذلـــ في المرحلـة السـابقة على خريطة المهمات التعليمية.

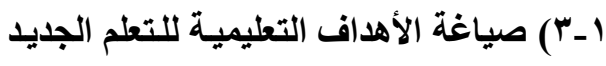

من خلال ترجمة خريطة المهمـات التعليمية التي تم التوصل إليها إلى ثمانية أهداف سلوكية نهائية هي (أن يتعرف الطالب على ماهية الإنفوجر افيك الثابت، التعرف على المهارات العامـة لإنتاج الإنفوجرافيك الته الثابــ، أن يتعـرف الطالـب على البيئسة الخاصــة

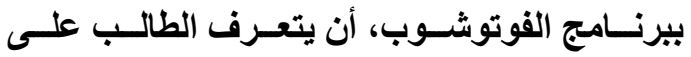
الأدوات الأساسية داخلـل صـندوق الأدوات ببرنـامج الفوتوشـوب، أن يتعـرف الطالـب عــى وظيفــة اللوحسات داخـل برنــامج الفوتوشــوب، أن يسـتخدم أدوات التحديد داخل برنامج الفوتوشوب، أن يتعامل الطالب مـع الرسوم داخل برنـامج الفوتوشـوب، أن يتعامـل الطالــب مــع النصــوص داخـل برنــامج (الفوتوشوب).
الجديد والتعلم السـابق على الخريطة وتم رسم هذا الخط في الخريطة الموجودة في الخطوة السابقة. ـ ـ تحليل خصـائص المتعلمين وسلوكهم المـذخلي: وهـي خصـائص طلاب الفئة العمريـة في عمر 1^اــ ا Y عـام وهم طلاب الجامعـة، وتم تقسيم المتعلمين

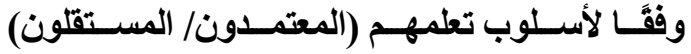
ومستوى السلوك المدخلي أنهم قادرن على التعامل مع أجهزة الكبيوتر والاتترنت، ولكن لم يسبق لهم

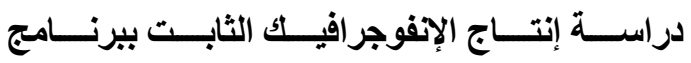
الفوتوشـوب وهنــا يتســاوى الســوك المـــلـي مـع المتطلبات السابقة للتعلم الجديد.

هـ تحليل التكلفـة والعائسد: تم تحديد تكلفة تصـميم بيئة التعلم النقال والمحتوى التعليمي وذلكـ وفَّا لمـا تتضمنه البيئة من إمكانيات. جـ تحليل الموارد والقيود في البيئة التعليميـة: تـم تحليل الإمكانيات التي ستسـاعد الباحثان في التطبيق وتــوفر الوقـت الــلازم للتصــــميم والإنتـــاج، وتــوفر المهارات الخاصة بالإتتاج والاستخدام. المرحلة الثانية: مرحلة التصمبِي: 1- تصميم الأهداف (الأهداف النهائية والممكنة): تـم تصـميم الأهـداف التعليميـة في صـورة سـلوكية الخاصـة بـالمقرر المحدد، ويعرف الهـدف السـلوكي بأنه نتاج تعليمي يكتسب بعد المرور بخبرة معينـة"، والنتـاج المطلـوب مـن المـتعلم إتقانـة بعـد مـروره

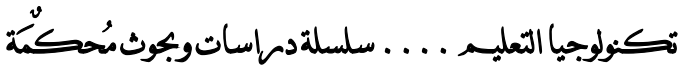


الجمعية المصرية لتكنولوجيا التعليم

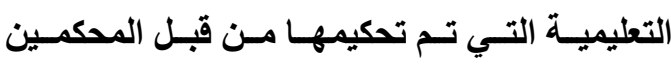
والوصـول إلى صـيغتها النهائيسة وعددهم ثمانيـة عناصر هي: ماهية الإنفوجرافيك الثابت التعليمي، المهارات العامة لإنتاج الإنفوجرافيك الثابت، البيــة الخاصـة ببرنـامج الفوتوشـوب، الأدوات الأساسية داخـل صـندوق الأدوات، وظيفـة اللوحــات، أدوات التحـيـد، التعامـل مـعـع الرســومات، التعامـل مــع النصوص.

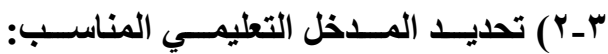
استخدم المدخل التقدمي الهجين المكون من المدخل تلقيني لتزويد المتعلمين بمعلومات وتعليمـات كاملة وصريحة محددة مسبقًا كتعليمـات استخدام البيئة، والأهداف التعليمية من دراسة المحتوى والمحتوى نفسـه، والمـــخل البنـائي المتمركـز حـول المـتعلم والأي يساعدهم في بنـاء التعلم بأنفسـهم من خلال ممارسـة الأنشـطة المختلفـة مـن خـلال بيــــة التتعلم النقـال ومــخل الوصـول الحر الــي يتيح للمـتعلم الحريـة الكاملـة في التجول بين المعلومـات وتقديم التلميحات الملائمة لهم، والوصول إليها والتثـارك في تنفيذ الأنشطة والتكليفات.

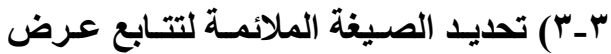
المحتـوى: تــم ذلــك فـي ضــو طبيعـة المهـــات التعليميـة، وخصـائص المتعلمـين، ونــوع البيئسـة

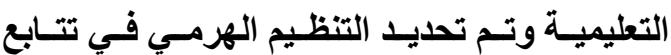
المحتوى الخـاص بمقرر إنتـاج الرسـوم التعليميـة لأنه هو المناسب لطبيعة المهمات التعليمية.
1 ـ ) تحليل الأهداف، حسب خريطة المهمات تم التحليل إلى أهداف نهائية و أهداف ممكنة، حيث تضمن كل هدف من الأهداف السابقة أهداف تعليمية إجرائية ممكنة بملحق (r).

ـــ تصـنيف الأهــاف حسـب بلـوم : قـام الباحثـان بتصنيف الأهداف المـراد تحقيقهـا حسب بلوم للأهداف التعليمية، حيث تم تحديد نوع الهدف ومسـتواه (تــكر، فهـم، تطبيـق، تحليـل، تركيب، تقويم) بملحق (r). Y - تصميم أدوات القياس محكيـة المرجع: استخدم الباحثنان في البحث الحسالي ثُلاث أدوات هم اختبار تحصيلي يهدف إلى قياس تحصيل الطلاب المعارف الخاصــة لإنتـــاج الإنفوجر افيـك بإســتخدام برنــامج الفوتوشـوب، بطاقــة تقيـيم أداء مهـــارات إنتـــاج الإنفوجرافيك الثابت بإستخدام برنـامج الفوتوشـوب لقيـاس الجانـب الأدائسي، اختبـار تفكيـر ابتكـــاري لمهـارات إنتـــاج الإنفوجرافيـك بإســخدام برنــامج الفوتوشـوب. وسـيتم تنـاولهم تفصـيليًا في الجززء

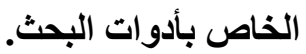

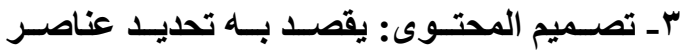
المحتوى ووضعها في تسلسل مناسب على حسب ترتيب الأهداف لتحقيق الأهداف التعليمية خلال فترة زمنية محددة وللقيام بذلك تم اتباع الخطوات التالية: r- 1 ) تحديد العناصر : الرئيسية للمحتوى في ضـوء خريطـة تحليـل مهمــات الـتعلم والأهـــاف

المجلد الثامن و العشرون .... العدد الثانى ـ ابريل 1 ـ ץ 
الجمعية المصرية لتكنولوجيا التعليم

تجمع بين عرض المحتوى المقدم مـن خـلال المعلم على بيئة التعلم النقال التي تثتثل على موديولات المقرر التي تم تحديدها من خلال نتائج الاستبيان الذي تم إجراؤه على الطلاب، والاكتشـاف من خلال اكتثــاف الطلاب للمحتوى الخـاص بأنشطة التعلم التي يعطيها المعلم للمتعلمين بحيث يقوم الطلاب بالبحث و التعليق ومشـاركة المعلومـات والأنشـة والمعارف من خلال بيئة التعلم النقال، وأيضا تقديم التلميحات لكل طالب حسب أسلوب تعلمه. צ-Y ) استـراتيجيات التعلم: تم اختيـار طريقة التعلم الهجينـة التـي تجمع بين استراتيجية التعلم المعرفية، والتي تضم معالجـة المعلومـات وتكاملها وتنظيمهـا وترميزهـا في العقل وقــ أتاحت البيـــة للطلاب محتّوى تعليــي مقدم عبر موقع تعليمي "كبيئة التعلم النقال" به موديولات وأنشطة المقرر ككل، فتم استخدام الاستراتيجيات المعرفية المختلفة في استيعاب المحتوى المقدم مـن خـلال استخدام أسلوب المحاضرات، المناقثة وغيره من الأسـاليب التي أتاحتهـا بيئسة التعلم وكنلك من خـلال توظيف الطلاب لمهارات المعرفة التذكر والفهم والتطبيق، وبين استراتيجية التعلم فوق المعرفية، والتي تهتم بـالتفكير في التعلم، التفكير الابتكـاري، والتوجيـه

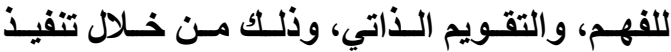
الطلاب لأنشطة التعلم من خلال بيئة التعلم النقال طبقًا لطبيعة المحتوى التعليمي للنشـاط أو الأنثطة المتنوعة التي سيقوم بها الطلاب سواء فرادى أو

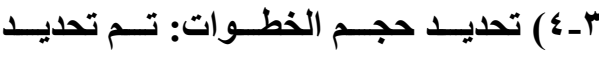

الخطوات الواسعة والتي تثـتمل على كم أكبر من المعلومات نظرًا لطبيعة المرحلة السنية المستخدمة

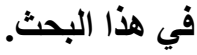

r_ه) تقسيم الموضوع إلى وحدات رئيسية: فقد تم تقسيم الموضوع وهو إنتـاج الإنفوجرافيك الثابت بإستخدام برنـامج الفوتوشـوب إلى وحدات رئيسية "موديـولات" وعددها ثمانية موديولات، وكل موديول إلى عناصر، وكل عنصر إلى أفكار، وكل فكرة إلى خطوات محددة تتضسمن المقدمة، والمطلومــات، والأمثلــة، والتـــريبات، والتعزيـز والتلميحات والرجع، ثم التلخيص والإنهاء. r-7) صياغة المحتوى: بحيث تكون الصياغة سـليمة حسب المعسيير المحسدة ولعمـل ذلــــــم عرض المحتوى على المحكمين وعددهم خمسـة محكمين تخصـص تكنولوجيـا التعلـيم والجر افيـك للتحقـق مـن ارتبـاط المحتـوى بالأهـاف، تسلسـل الأفكــار والترتيـب المنطقـي، مناسـبتها للطـلاب، واتفق المحكمين على سـلامة المحتوى اللغوي، وارتباطهـا بالأهــاف، وتسلســلها المنطقـي، وقـــ تضــن المحتـوى ثمانيـة موديـولات تعليميـة وفقَّا للمهمات المحددة مسبقًا. ع ـ تصميم استراتيجيات وأساليب التعليم والتعلم: ع - 1) اسـتراتيجيات التعلـيم: وقــــــم اختيـار استراتيجية الجمع بين العرض والاكتثـاف، حيث

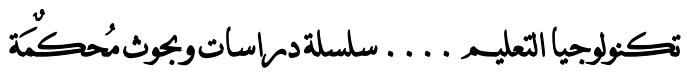


هـ 1 ) تصميم نمطي التلميحات:

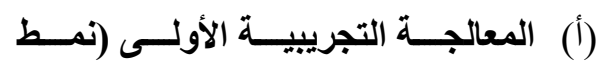

التلميحات المكتوب): يقوم المعلم بتقديم

المهمات التعليمية عبر بيئة التعلم النقال

ثم يقوم المتعلم بتنفيذ المهمـات والأنثطة

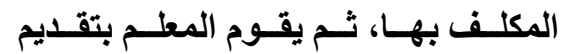

التلميحــات المكتوبــة للمتعلمـين وفةَّــا

للأسلوب المعرفي وذلك وفقَّا لطبيعة تنفيذ النشاط الذي قام به كل متعلم.

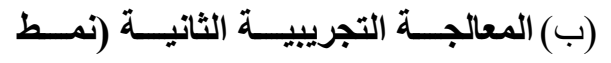

التلميحـات اللونيـة): يقوم المعلـم بتقديم

المهمات التعليمية عبر بيئة التعلم النقال

ثم يقوم المتعلم بتنفيذ المهمـات والأنثطة

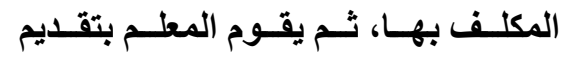

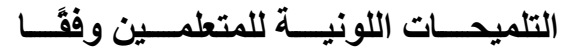

للأسلوب المعرفي وذلك وفقًا لطبيعة تنفيذ

النشاط الذي قام به كل متعلم.

Y_o ) تصميم استراتيجيات التفاعل في بيئة

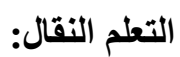

(أ) دور المطــم: يتمثل في توجيـه المتعلمين

وإرشادهم، وتقديم تعليمات استخدام بيئة

التتطم النقـال، تنظيم التفاعل بين أفراد

المجموعـات، تقديم الأنثـة و التكليفـات

للمتعلمين، توزيع المهام على المتعلمين،

تثـجيع الطـلاب وحثـهم على اسـتخدام
مجموعـات، فتســـح بيـــة الـتـلم النقــال للطـلاب بتثارك المعارف، والتعليق على موضوعات التعلم وتقايم التلميحات اللازمة، والبحث والاكتثــف عن المعسارف المختلفـة، وتنميـة التفكير الابتكـاري إلى غير ذلك من مزايا. وتم استخدام استراتيجية التعلم التي تجمع بين المعرفيـة وفوق المعرفية مـع بيئة التعلم لمجموعـات التعلم الأربـع الذين اسـتخدموا (تقديم التلميحات المكتوبـة مـع الطلاب المستقلون، تقديم التلميحـات المكتوبـة مـع الطلاب المعتمدون، تقديم التلميحـات اللونيـة مـع الطـلاب المستقلون ، التلميحات اللونية مع الطلاب المعتمدون). ه ـ تصميم نمطي التلميحات وتصميم استراتيجيات التفاعلية والتحكم التعليمي في بيئة التعلم النقال: يقصــد بــه تحليـــ دور المعلــم والمـتعلم وكيفيـة تقـــيم التلميحــات، وتحديــــــــل البيئــة التعليميـة وهـي بيئسة التعلم النقــال، ونوعيـة هـــه التفــاعلات، وهنـا سـتكون بيـــة التـعلم النقـــال لهـا شكلين وفقَا لنمط التلميحـات بحيث لكل مجموعة بيئسة خاصـة بهـا حسب نمـط التلميح المقدم. ويـتم التفاعل مع كل مجموعة حسب نمط التلميح المقدم والأسـلوب المعرفي، وفيمـا يلـي توضسيح لتصـميم نمطـي التلميحـات واسـتراتيجية التفاعل في بيئسة

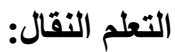

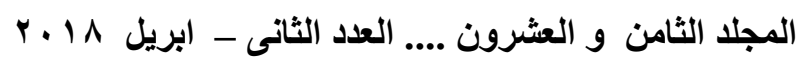


الجمعية المصرية لتكنولوجيا التعليم

إضــافية عنـــ الحاجـة إليهـا، ومـن خـلال بعـض

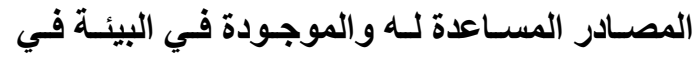
الجزء الخاص بالمحتوى وأنشطته.

- V تصميم استراتيجية التعليم العامـة: استتـد البحث الحسالي على مقترحات النمـوذج المتبع في تصـميم

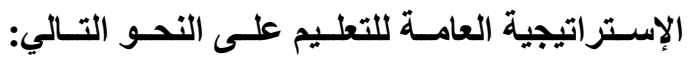

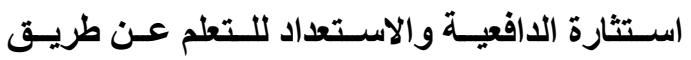

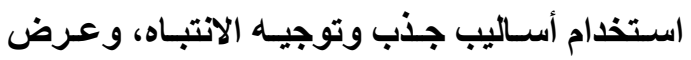

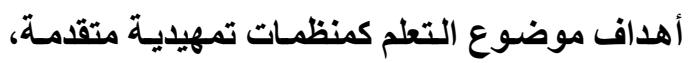
مـع ربطهـا بموضـوعات الـتـعلم الســابق لتحقيـق التهيئة المناسبة لبدء التعلم، تلي ذلك تقديم التعلم

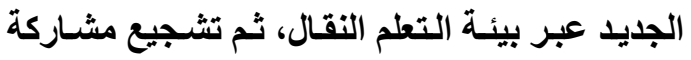
المتعلمين وتنشيط استجاباتهم عن طريـق توجيـه التعلم، وتقديم أسـاليب التعزيز والدعم والتلميحـات

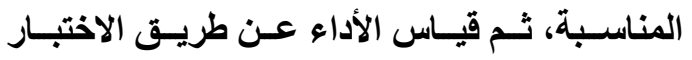
المحكي، وأخيرًا ممارسة التعلم وتطبيقة في مواقف جديدة كما في ملحق ( ) ). ^ـ اختيار مصسادر التعلم ووسـائله المتعددة: يعتمد مصدر التعلم في البحـث الحسالي على بيــة التعلم

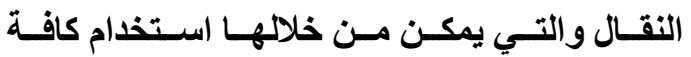
المصادر التعليميـة بكافـة أثكالها وبإستخدام الكثير مــن الوســائل، النصــوص، و الفيــيو، الرســـوم المتحركـة، والصـور والرسـوم الثابتـة، والصـوت، وغير هم وهذه الوسـائل تتكامـل فيمـا بينهـا لتقديم

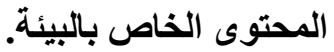

ـ ـ تحليد مواصفات ومعسيير الوسـائط المستخدمة في بيئة التعلم النقال: وقد تم تحديد هذه الخطوة قبل البدء في بلاية خطوات البحث.

$$
\begin{aligned}
& \text { مهـــارات التفكيــر الابتكـــاري، وتقــــيم } \\
& \text { التلميحـات علـى الأنثـطة المنفــــــــن } \\
& \text { الطلاب. }
\end{aligned}
$$

(ب) دور المـتعلم: يتمثـل فـي قيامسه بمتابعـة

موضوعات التعلم عبر بيئة التعلم النقال، قيامـة بتنفيـــ الأنثــطة و التكليفــات ثــم

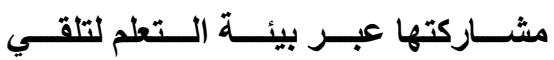

التلميحات اللازمة، التفاعل والتواصل مـع

$$
\text { أقرانة والمعلم. }
$$

7ـ المســاعدة والتوجيـه: تثـتمل بيــة التعلم النقـال على آليات معينة لتقديم المسـاعدة والتوجيـه للمتعلم لتســاعده فـي تـذليل العقبـات وتوجهـه نحسو إنجـاز

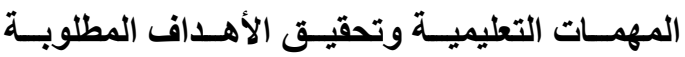
بفاعلية هذه المساعدات تتمثل في: ـ مســاعدات التشـيل والإسـتخدام وذلـك مـن خلال إعداد دليل للمستخدم يتضمن كيفية استخدام

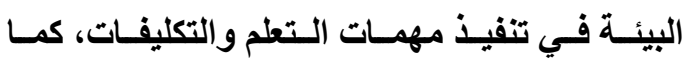
يتضــن معلومــات حـول البيئسة تثـــل تســيتها، وأهدافها، والمنتج المراد من استخدامها، معلومـات حول المحتوى الموجود بالبيئة، تعليمات للبحث عن معلومـات بإستخدام بيئة التعلم، تعليمـات اسـتخدام واجهة تفاعل البيئة. ـ مسـاعدات تعليميـة لتعليم المحتوى تسـاعد المـتطم فـي الحصـول على معلومسات تفصـيلية أو شرح مفهوم أو شكل مثل عرض معلومسات تفصيلية

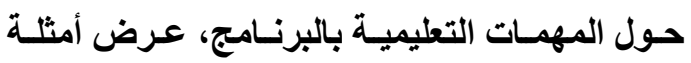

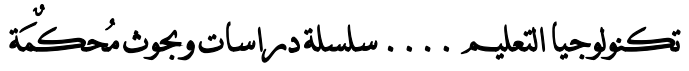


الجمعية المصرية لتكنولوجيا التعليم

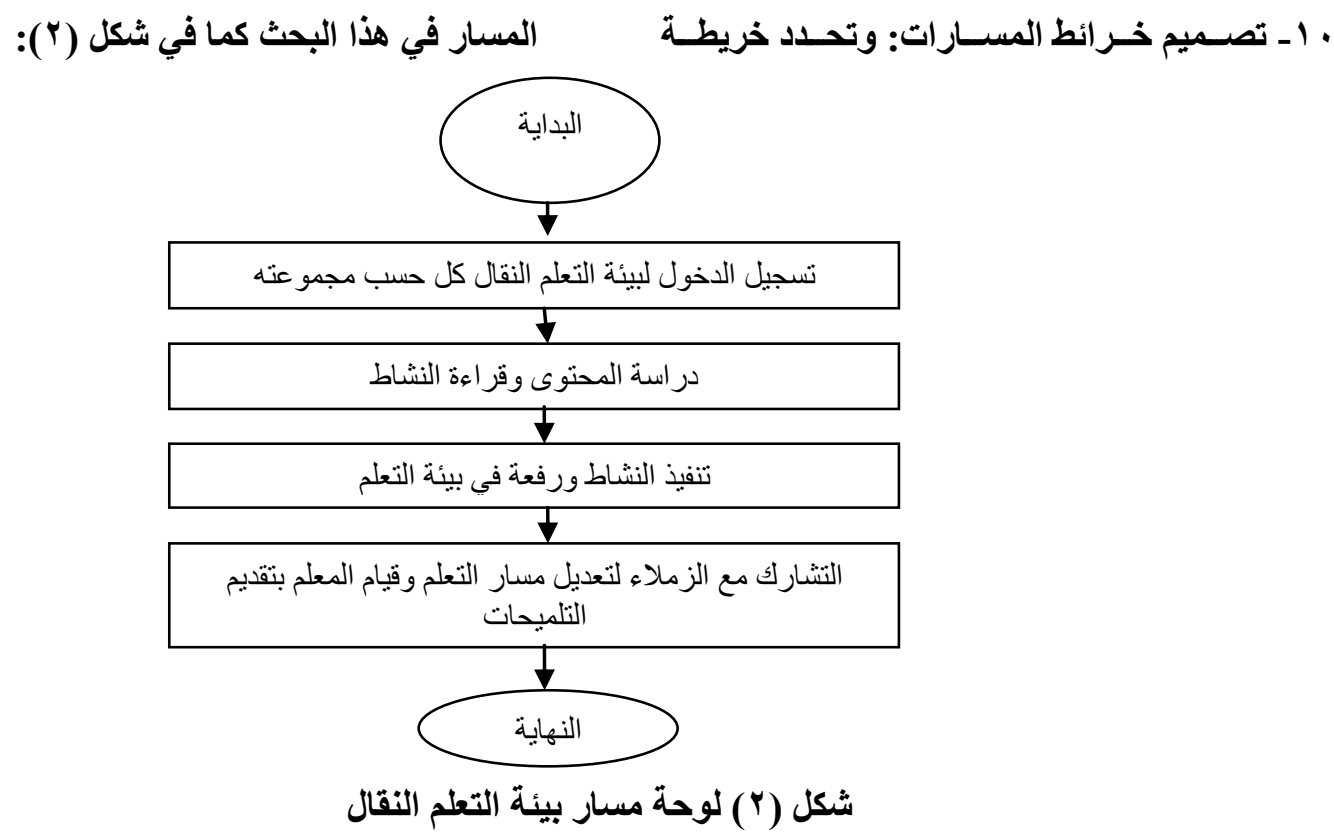

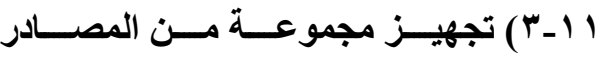

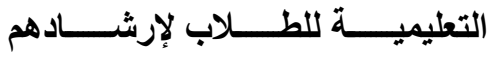

ومعـاونتهم على البحث العلمسي في

ضوء الأهداف التعليمية وشملت هذه

المصــادر مجموعـة مسن محركسـات

البحث، والمواقع التعليميـة، والكتب

$$
\text { متاحة في البيئة. }
$$

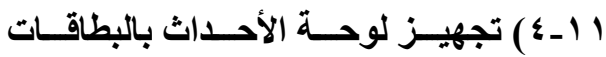

وتثبيتهــا وكتابـة المعلومــات المطلوبـة لكـل فكـرة

وفيــا يلـي شكل (َّ) يوضـح واجهة التفاعل لبيئة

التعلم النقال المستخدمة في البحث الحالي:
1 اـ تصـميم بطاقـات لوحسة الأحسداث والثـاثــات:

وهنـا يجب الإثـارة إلى أن الباحثنان سيقوم بوضع لوحة أحداث خاصـة بـالمحتوى التعليمي المقدم من خـلال بيئـة الـتـطم النقـــال وكيفيـة تنفيـذ الأنثـطة و التكليفــات المطلوبـة مـن الطـلاب وفقَــا للمحتــوى

التعليمسي. وتضــنت هـذه الخطـوة مجموعـة مـن

$$
\text { الخطوات هي: - الخي }
$$

1 - 1 - ) ترتيب الأهداف والمحتوى والخبرات

$$
\text { التعليمية في بيئة التعلم النقال. }
$$

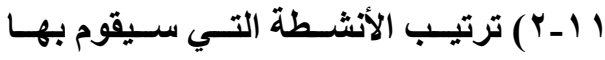

الطـلاب لجمــع المحتــوى وتقـــيم

التلميــات مـن خـلال بيئسة التـعلم

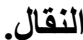


الجمعية المصرية لتكنولوجيا التعليم

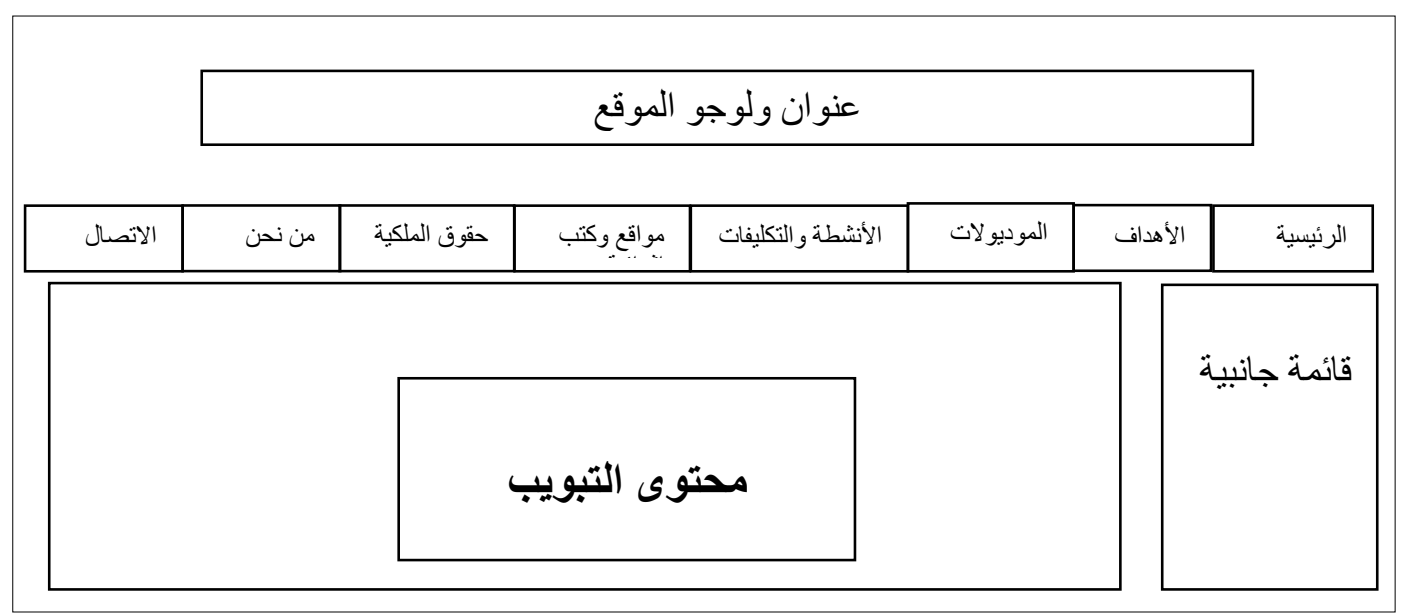

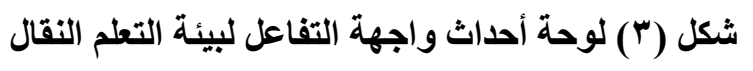

التفاصيل المطلوبـة اللازمـة لبيئة التعلم النقال

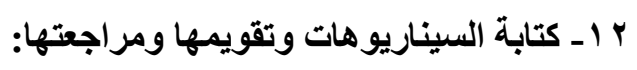

كما هو موضح بشكل (\&):

1 ـ كتابة السيناريو: تم اختيار السيناريو متعدد

الأعمدة نظرا لدقة التطوير التكنولوجي وتوافر

\begin{tabular}{|c|c|c|c|c|c|c|c|}
\hline الإبحار & الفيديو & الصوت & النص المكتوب & وصف محتوى الاطار & كروكي الإطار & العنوان & رقم الاطار \\
\hline
\end{tabular}

شكل (؛ ) سيناريو تصميم بيئة التعلم النقال

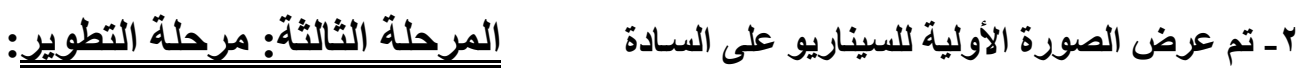

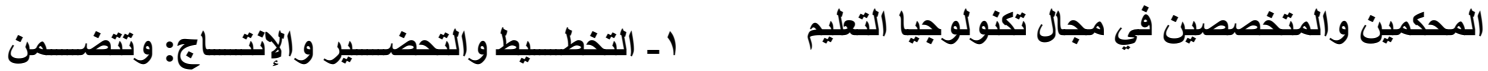

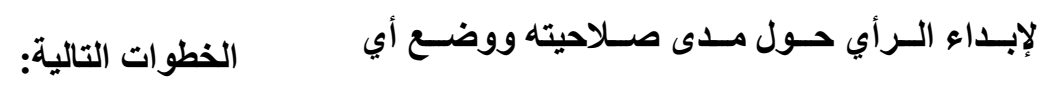

1 - 1 ) اختيار فريق الإنتاج وتحديد المسئوليات

والإدارة: قــام الباحثــان بكتابــة المــادة

العلمية، والعمل على التصميم التعليمي

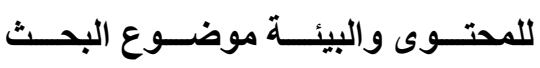

مقترحسات أو تعديلات أو حذف أو إضـافة مـا يرونـة مناسبًا ثم قام الباحثان بالتعديل وفقا لآراء المحكمين وتم التوصل إلى الصيغة النهائية للسيناريو الخـاص بيئــة الـتـعلم النقـال والصــورة النهايـة للسـيناريو

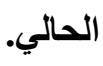

بملحق (†). 
r- إنتاج مكونات بيئة التعلم النقال:

r- 1 ) كتابــة النصــوص: وقــــ تمــت كتابتهــا ببرنامج الوورد وتنسيقها ثم لصقها وإعادة تنسـيقها على الموقـع المتضـَمن فـي بيئسة التعلم.

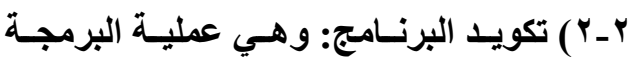
وتنفيذ المحتوى على الكمبيوتز والإنترنت، وقد استعان الباحثّان ببعض لغات البرمجة مثل لغة تحديد النصوص الفائقة، وبرنـامج

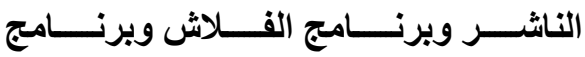
الفوتوشـوب لتنفيـذ لوجـو الموقـع، وبعض البرامج الخاصـة بإتتاج العروض التقديميـة عــى الويـبـ، وبــرامج تسـجيل الفيــديو، وإنتاجـه وإنتــاج الجرافيـك، بـرامج تقطيـع الصوت لوضعها في الفلاش.

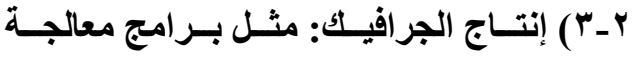
الصـور الفوتوشـوب، برنــامج الفـلاش والــريم

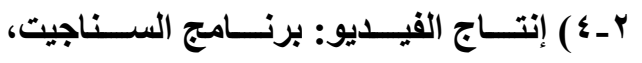
استخدام كاميرا رقمية.

ץ-0) تسجيل الصوت: من خلال برنامج تسجيل الصوت الموجود بنظام التشغيل ويندوز.

rـ تجميع المكونات، وإخراج النسـخة الأولية لبيئة

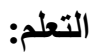

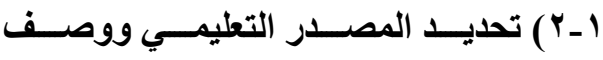

مكوناتـهـ وعناصـره: وفـي هـذا البحـث يوجد مصدر للتعلم هو بيئة التتطم النقال وتتكـون مـن مجموعـة مـن الصـفحات، والبيئـة مصــمـه بحيـث تتـيح للمـتعلم التفاعل والتثارك.

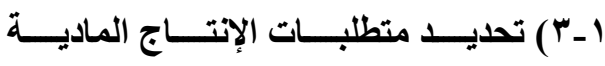
والبشرية: يجب أن يتوفر أجهزة حاسب

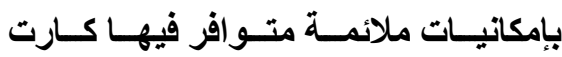
للفيديو محمل عليه برامج لتسجيل لقطات الفيـديو لإمكانيـة تســيلها ورفعهـا على تـى الانترنت، برامج لمعالجـة النصوص لعمل الأبحــاث المطلوبـة، وبرنــامج العـروض التقديمية، ومشغل الفلاش • 1 على الأقل، أمسا بالنسبة بالمعـالج فيكون سرعتة على

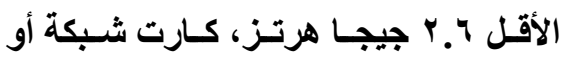
كسارت فـاكس، تـوافر الاتصـال بالإنترنــت للتمكن من تصفح الموقع. 1 - ؛ ) وضـع خطة وجدول زمنـي للإنتـاج: تـم وضـع مدة سبعة أسـابيع للبدء في إنتـاج البيئة بـالمحتوى الذي تم وضعه والقيـام بالأنشطة المطلوبة. 
الجمعية المصرية لتكنولوجيا التعليم

والطول، والنواحي التربوية والفنية، والنواحي التي غقلنا عنها والملاحظات والمقترحات الأخرى.

צ-Y) عرض النسخة الأولية على عينـة من

الخبـراء والمحكمـين تخصـص تكنولوجيـا التعلـيم

وعـدد هم خمسـة، وعينـة مـن المعلمـين، وتطبيـق

الاستبيانات المناسبة.

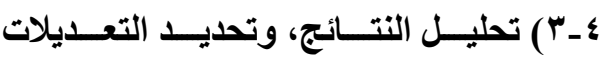

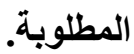

هـ إجراء التعديلات، والإخراج النهائي لبيئة التعلم:

فـي هـذه الخطـوة يـتم إجـراء التعـديلات

اللازمسة في ضـوء نتـائج التقويم البنـائي، وإجراء

التثطيبات النهائيـة لإخراج النسـخة النهائيـة لبيئة

التعلم النقال، وتثـمل: ضبط بعض بنط الخطوط، تنسيق بعض الكلمات والفقرات، تغيير بعض الصور والرســوم، إضــافة بعـض المعلومسات والثاثــات، تغيير ألوان بعض النصوص. المرحلة الرابعة: مرحلة التقويم التهائي وإجازة بيئة التعلم: لئية

فـي هـــه المرحلـة يـتم تطبيـق بيـــة الـتـطلم المصــمة علــى عينــة كبيــرة مــن المتعلمـين المستهلفين في مواقف التعليم الحقيقية، وتتضسن

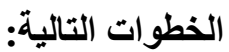

ب- 1 ) تجميع ملفـات بيــة التعلم المصـمـة

حسب الترتيب المحدد لها.

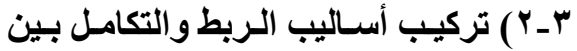

بيئة التعلم المصممة.

r-r تركيب أساليب التفاعلية وضبطها.

بــ ) تركيب أسـاليب الإتتقـال و التفرعـات

وضبطها.

بــ) إنتاج النسـخة الأولية لصفحات بيئة

الـتـعلم وواجهــة التفاعـل حسـبـ

السيناريو.

بـ 7) إجراء المعالجات الأوليـة لبيئة التعلم بالحذف والإضافة والتعديل.

ـ ـ تجميع المكونات، وإخراج النسخة الأولية لبيئة

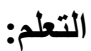

بعد الانتهاء من إنتاج النسخة الأولية، يتم تقويمها وتعديلها، قبل عملية الإخراج النهائي لها

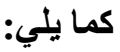

ـ ـ ا ) عـرض النســة الأوليــة علـى عينــة

صغيرة من الفئسة المستهدفة عددهم سبعة طلاب، وتطبيق الاختبـارات والاسـتبانات المطلوبـة؛ للتأكد من مناسبتها لتحقيـق الأهداف وتسلسـل العرض، ومناسبة العناصر المكتوبة والمرسومة والمصورة، وجودتهـا، والتـرابط والتكامـل بـين هذه العناصـر،

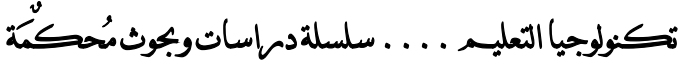


الاختيبار من متعدد على • ج مفردة، وتم تعديل

مفردات الاختبار بناء على آراء المحكمين إلى بـ ؛

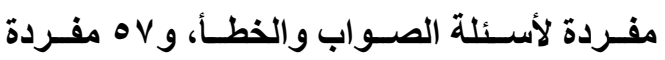
لأسـئلة الاختيـار مـن متعـد ليكون عدد الأسـئلة . . . سؤال وبالتالي تكون الارجة الكلية للاختبار

$$
\text { - 1. }
$$

1 ـ ) جـدول مواصـفات الاختبـار: تـم إعـداد جدول المواصفات بحيث يوضح الموضوعات التي

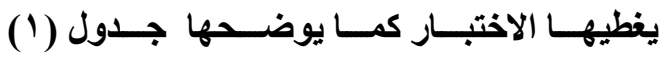
مواصفات الاختبار التحصيلي:
1 ـ تحضسير أدوات التقويم المناسبة: اختبـار

تحصــيلي، بطاقــة تقيــيم الأداء، اختبــار

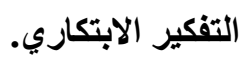

r. التطبيق القبلي لأدوات القياس والتقويم.

r. تجربـة بيئسة التعلم على عينـة أكبر فـي

مواقف تعليمية حقيقية.

ع. رصد النتائج، ومعالجتها إحصائيا.

ه. تحليل النتائج، ومناقشتها، وتفسيرها.

7. اتخاذ القرار بثـأن الاستخدام أو المراجعة

$$
\text { ثالثا: أدوات البحث }
$$

1) اختبـار تحصيلي للجوانب المعرفيـة: وإجراءات تصميمه وفق الخطوات التالية:

1 - 1 ) تحديد الهدف من الاختبار التحصيلي:

يهدف الاختبـار إلى قيـاس مـدى تحصيل طـلاب

الفرقة الثانيـة تخصص تكنولوجيـا التعليم (عينـة

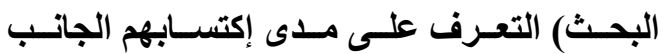

المعرفي لمهارات تصميم الإنفوجر افيك الثابت.

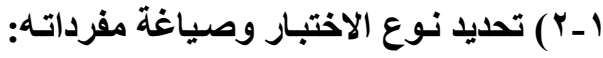

تم إعداد الاختبار التحصيلى في صورة عبارات الصواب والخطأو عبارات الاختيار من متعدد.

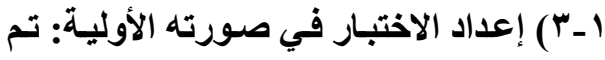

إعـداد الاختبـار في صـورته المبدأيسة واشـتملت

أسئلة الصواب والخطأ علي ه ؛ مفردة، وأسئلة

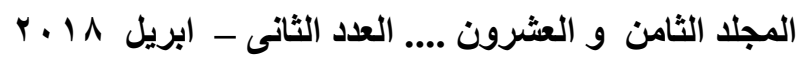


جدول (1) مواصفات الاختبار التحصيلي

\begin{tabular}{|c|c|c|c|c|c|c|}
\hline \multirow{2}{*}{ النوزن - المبن } & \multirow{2}{*}{ المجموع } & \multicolumn{3}{|c|}{ مستويات الأهداف المعرفية } & \multirow{2}{*}{ موضوعات الاختبار } & \multirow{2}{*}{ R } \\
\hline & & تطبيق & فهم & تذكر & & \\
\hline$\% 1$. & 1. & . & $\varepsilon$ & 9 & ماهية الإنفوجر افيك الثابت التعليمي & 1 \\
\hline$\% 10$ & 10 & . & 10 & . & التعهارات العامة لتصميم الإنفوجرافيك & r \\
\hline$\% 1$. & 1. & . & r & $\wedge$ & بيئة العمل في برنامج الفوتوشوب & $r$ \\
\hline$\%$ & $r \varepsilon$ & - & - & $r \varepsilon$ & 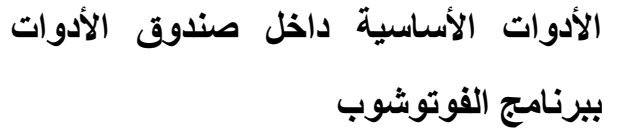 & $\varepsilon$ \\
\hline
\end{tabular}

\begin{tabular}{|c|c|c|c|c|c|}
\hline$\%$ & 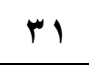 & $\cdot$ & . & 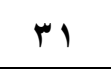 & وظائف اللوحات داخل برنامج الفوتوشوب \\
\hline $1 \ldots$ & \multirow{2}{*}{$1 \ldots$} & $\cdot$ & rI & Vq & المجموع \\
\hline$\%$ & & $\%$. & $\%$ & $\% \vee q$ & الوزن النسبي \\
\hline
\end{tabular}

التعديلات اللازمة وفقًا لأرائهم حول (مدى قياس الأســلئة للأهـــاف، شـــولية الأســـلة لعناصـر المنهج، مدى مناسبة الأسئلة لعينـة البحث، الدقة العلمية واللغوية لبنود الاختبار) وأصبح الاختبار جاهزًا لإجراء التجربة الاستطلاعية.

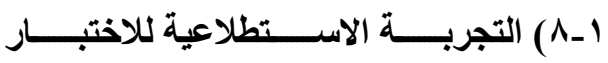
التحصيلي: تم تطبيق الاختبـار على عينـة مكونـة مـن سـبعة طـلاب مـن الفرقـة الثانيـة تخصـص تكنولوجيـا تعلـيم بكليـة التربيـة النوعيـة جامعـة المنوفية بهدف:

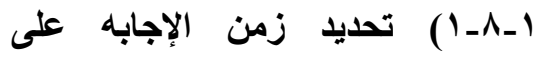
الاختبار التحصيلي: تم حساب الزمن الذي أستغرقه الطلاب عند الإجابة على الأسئلة،
1 ــ) وضع تعليمات الاختبار التحصيلي: وقد راع الباحثــان فـى تعليمـات الاختبـار أن ( تكـون واضحة ومباشرة توضح ضرورة الإجابـة عن كل الأسئلة، تبين للطالب كيفيـة استخدام الفـأرة فى الإجابة على أسئلة الاختبار). 1 - 7) إعداد نمـوذج الإجابـة ومفتـاح تصـيح الاختبـار التحصـيلي: تـم إعـداد نمـوذج للإجابـة بحيث يـتم تصـيح الاختبار باستخدام الكمبيوتر

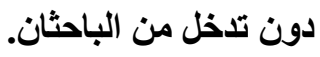

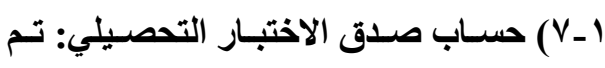
عرض الصورة الأولية للاختبار على مجموعة من المحكمين تخصسص تكنولوجيـا التعلـيم وعـدهم خمسـة، وذلــك لحســاب صــق الاختبـار وإجـراء

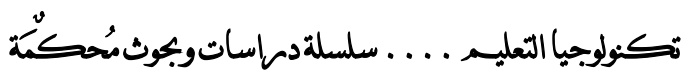


الجمعية المصرية لتكنولوجيا التعليم

وذلك عن طريق حساب متوسط زمن الاختبار، قائمة مهارات وبطاقة تقييم الأداء المهاري:

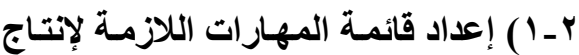
وكان متوسط الزمن (ro) دقيقة بالنسبة الإنفوجرافيـك الثابـت بيرنـامج الفوتوشـوب فـي لألفراد المجموعة الاستطلاعية. البحث الحسالي: تـم إعداد قائمسة المهـارات وفق

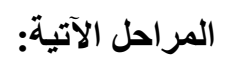

حساب معاملات السهولة (Y_A_-1

والصعوبة والتمييز لمفردات الاختبار: امتلات

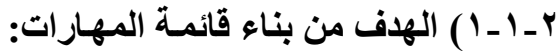
معاملات سهولة مفردات الاختبار ما بين تهذف بناء قائمسة المهارات إلى تحيد المهارات اللازمة لإنتاج الإنفوجرافيك الثابت التعليمي ببرنامج الفوتوشوب.

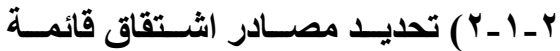
المهارات: تم الاعتماد علي مقرر إنتاج الرســـوم التعليميــة بالفرقــة الثانيــة تخصص تكنولوجيـا التعليم بالاضــافة إلسي مراجع تـم تحديدها في الخطوات

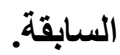

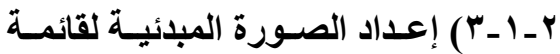
المهـارات: مـن خـلال مصــادر اشـتقاق قائمة المهارات تـم التوصل إلى وضع صـورة مبلئيسة لقائمسة مهـارات إنتـاج الإنفوجر افيك الثابت بإستخلام برنـامج الفوتوشـوب، والتـي تكونـت مـن أربـع

$$
\text { مهارات رئيسة. }
$$

r ـ ا ـ ) عرض الصـورة المبائيـة لقائمـة المهارات على المحكمين: تم عرض

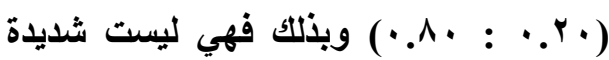
السهولة ولا الصعوبة، وتراوحت معاملات

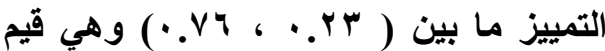
مقبولة وهذه القيم تسمح باستخدام الاختبار في قياس تحصيل الطلاب.

(Y-A_l

التحصيلي: تم حساب ثبات الاختبار بطريقة التجزئة النصفية "لسبيرمان وبراون" وكان معامل ثبات الاختبار التحصيلي هو (9^^. ) وهو معامل يشير إلى أن الاختبار على درجة مقبولة من الثبات، ويعنى ذلك أن الاختبار يمكن أن يعطى نفس النتائج إذا أعيد تطبيقه على العينة نفسها في نفس الظروف.

1 ـ9 الصـورة النهائيسة للاختبـار التحصيلي: بعد قيـام الباحثـان مـن التأكد مـن صـدق وثبـات الاختبـار أصبح الاختبـار مكونـا مـن . . 1 مفردة ويستخدم لقياس مدى تحصيل طلاب الفرقة الثانية تكنولوجيــا التعــيم الجاتــب المعرفــي الخــاص بمهــارات إنتــاج الإنفوجرافيـك الثابــت بيرنــامتج الفوتوشوب، بملحق (V) - (V). 
الجمعية المصرية لتكنولوجيا التعليم

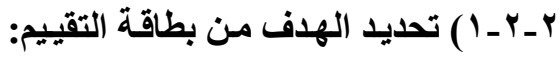

هدفت بطاقة التقيّم إلى تقدير كفـاءة

طلاب الفرقة الثانية تكنولوجيا التعليم

في مهارات إنتاج الإنفوجرافيك الثابت

بإسـتخدام برنـامج الفوتوشـوب، وذلـك

بأســلوب التقيـيم المسـتند إلـى الأداء

بوضــع الطالــب فــي موقـف يشـبة

الممارسة الواقعية، ويطلب منـه إنجـاز

المهمات يوظف من خلالها مـا أكتسبة

من معارف ومهارات ويترجمها لمنتج

$$
\text { يتم التقييم عليه. }
$$

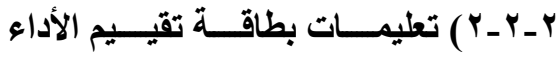

المهــاري: وضـعت تعليمـات البطاقـة

واضـــحة و شـــاملة أمــــا بالنســـبة

للملاحظين غير الباحثان فقد تم تحديد

هـف البطاقـة فـى التعليمـات كمـــــم

تحديد معيار لتحديد أداء الطلاب.

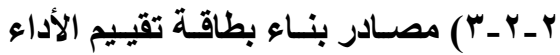

المهـاري: تـم بنـاء البطاقـة مسن خـلال

المحتوى التعليمي الذي تم تحديده كمـا

في الجزء الخـاص بالتصميم التعليمي

كما في مقرر إنتاج الرسوم التعليمية.

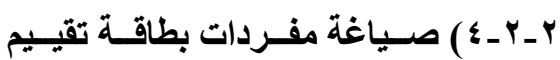

الأداء: تـم صـياغة بنـود البطاقـة فـي

صـــورة عبـــار ات ســلوكية تثــــل
الصورة الأولية لقائمسة المهارات على

مجموعـة مــن المحكمسين تخصـص

تكنولوجيــا التعلـيم وعـده هم خمسـة،

وذلــك لإبـــاء الــرأي حـول مـــــــي

(التعـــــيل بالإضــــــافة أو الحــــــف

للمهــارات، مــدى مناسـبة المهــارات

لعينـة البحثث). وتـم إجـراء التعـديلات

التى اقترحها المحكمين سواء كاتت فى

تعـديل بعـض الصــياغات اللفظيـة أو

حذف بعض المهارات، وتمثلت في

إعـــادة الصــياغة اللفويـــة لـــبعض

المهــارات، وحـف بعضض المهــارات

نظرًا لتكرارهـا، وفتك بعض المهارات

المركبـة، واتفـــوا جميعًا أن القائمسـة

مناسبة لعينة البحث.

r ـ ـ ـ ) إعـداد الصـورة النهائيـة لقائمــة

المهــارات: بعـــ إجــراء التعـديلات

اللازمــة وفقــا لأراء المحكمسين، قـام

الباحثـان بإعداد قائمـة المهارات في

صورتها النهائية، اشتملت على أربع

مهارات رئيسـة و ب مهـارة فرعيـة،

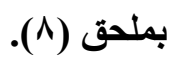

r Y r T إعداد بطاقة تقييم الطلاب في مهارات

إنتاج الإنفوجرافيك الثابت ببرنـامج الفوتوشـوب:

تم إعداد البطاقة وفق المراحل الآتية: 
الـرأي حـول مــا يلي:(مســى ارتبــاط

المهارة للأهداف، مدى مناسبة البطاقة

لعينـــة البحـــ، تصـــيح الصــياغة

اللغويـــة، مـــى صــلاحية البطاقـــة

للتطبيـق، حسـاب صـدق بطاقـة تقيـيم

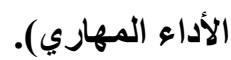

اعتمد الباحثنان فى تقدير صدق (V-r_r

البطاقة على الصدق الظـاهري: ومـن

خــلال عــرض بطاقــة تقيــيم الأداء

المهاري على مجموعة من المحكمين

تخصـص تكنولوجيـا التعلـيم وعـددم

خمسة و إبداء رأيهم في البنود السـابقة

تــم حســاب الصـــق الظــاهري للبطاقـة

وذلـــك مـن خــلال إجــراء التعـديلات

المقترحة التي أتفق عليها المحكمين،

والتي تمثلت فى: (تعديل صياغة بعض

بنـود بطاقـة تقيـيم الأداء لتصبـ أكثر

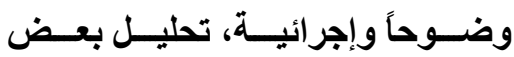

العبـارات إلـى عبـارات أو أداعات أقـلـ

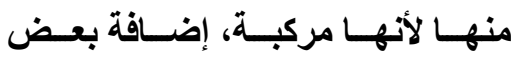

الكلمــات التــي توضــح كيفيـة إجـراء

المهارة وذلك لتصبح البطاقة جـاهزة

$$
\text { للتجربة الاستطلاعية). }
$$

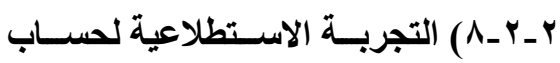

ثبــات بطاقـة تقيـيم الأداء: تـم حسـاب

ثبــات بطاقـة تقيـيم الأداء عـن طريـق
المهــــارات التــــي يضــــــها إنتـــــاج

الإنفوجرافيــك بيرنــامج الفوتوشـوب

واشـتمل على أربـع مهــارات رئيسـة

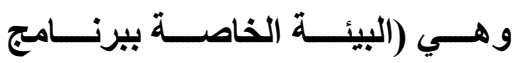

الفوتوشـوب، اسـتخدام أدوات التحديــ

داخل برنامج الفوتوشوب ، التعامل مع

الرسـوم داخـل برنــامج الفوتوشـوب،

التعامـل مـع النصـوص داخـل برنــامتج

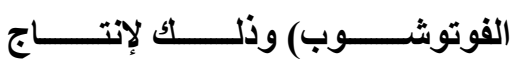

الإنفوجرافيك الثابت بإستخدام برنـامج

$$
\text { الفوتوشوب. }
$$

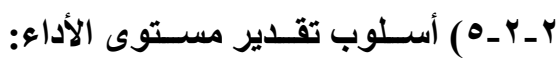

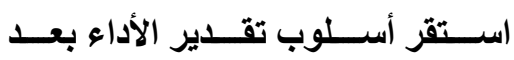

استطلاع رأى المحكمين على استخدام

نمسط التقسيم لثثلاثـة مسـتويات لتقدير

المهارة، فالمستوى "درجتان" لـلأداء

الصحيح، والمستوى "درجة واحدة"

بـأن يكتشـــ المـتعلم اجابتـهـ الخاطئسة

ويقوم بتصـيحها بنفسـه، والمستوى بـون

الثالـث يأخــ الارجـة "صـفر" لـلأداء

الخـاطئ وعدم الأداء و الارجـة الكليـة

للبطاقة هي ^ ؛ درجة.

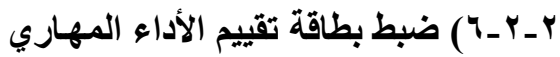

بعرضـها على المحكمـين: تـم عـرض

الصسورة الأوليـة لبطاقـة تقيـيم الأداء

المهاري على المحكمين، وذلك لإبداء

المجلد الثامن و العشرون .... العدد الثانى ـ ابريل 1 ـ r 
الجمعية المصرية لتكنولوجيا التعليم

لـدى طـلاب الفرقـة الثاتيـة تكنولوجيـا التعليم فى إنتاج الإنفوجرافيك الثابت بإستخام برنامج الفوتوشوب، وذلك فى ضـــوء تعريــف مصــــلح التفكيــر الابتكـارى الذَى تبنـاه الباحثـان، وهـو قدرة الفرد على الإنتاج إنتاجًا يتميز بـأكبر قـــر مـن الطلاقــة والمرونــة و التلقائيـــة والأصـــالة، ويالتــــاعيات البعيدة كاستجابة لمشكلة أو موقف أو مثير نتيجه دراسته ببيئة التعلم النقال.

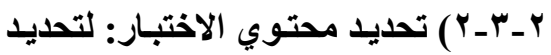
محتوى الاختبار تم الإطلاع على عديد

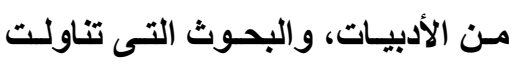
التفكير الابتكارى، وكذلك مجموعة من اختبارات التفكير الابتكارى التى سبق إعــدادها واســتخد/مها مثــل اختبــار تورانس(1962) Torrance ترجمـة وإعـداد (عبـــ الله سـليمان، فـؤاد أبـو حطب، · V V I )، واختبـار القدرة على التفكير الابتكارى الذى أعده (سيد خير

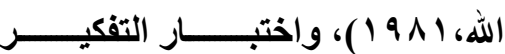
الابتكارى فى الرياضيات (طلال عامر ، I . . P)، واختبـار التفكيـر الابتكــارى

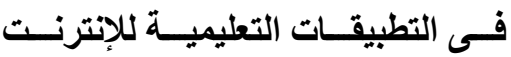

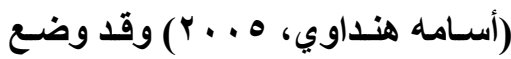
الباحثــان الاختبـارات السـابقة موضـع
أســلوب تعـدـد الملاحظـين علـى أداء الطالب الواحد من حيث تقييم المنتج

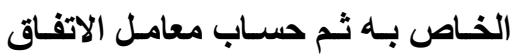
بين تقديرهم للأداء عن طريق استخدام معادلة "كوبرCCooper" لتحديد نسب الاتفاق. حيث قام الباحثان واثنين من زملائسه لتقيـيم أداء ثثلاثـة مـن الطـلاب، ثم حساب معامل الاتفـق على أداء كل

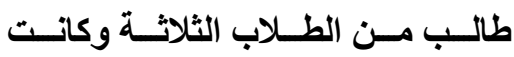

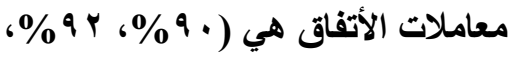
^^^^) وهذا يوضـح أن بطاقة تقيـيم الأداء التي تم تجريبها صالحة للقياس، حيـث بلـن متوسـط معامـل الاتفـاق في الـي الحسالات الثتلاث ـ 9\% ممـا يعنى أنها ثابتة إلى حد كبير.

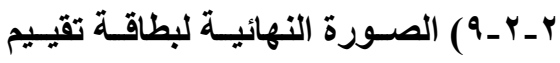
الأداء: بعد الإنتهاء مسن تقدير صدق وثبــات بطاقـة تقيـيم الأداو، أصسبحت البطاقـة فـى صسورتها النهائيـة صـالحة للتطبيق لتقييم منتجـات الطلاب بملحق

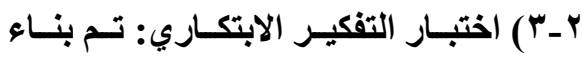
الاختبار وفقا للخطوات التالية

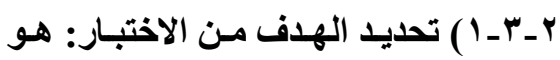
قيـاس القدرة على التفكير الابتكـارى

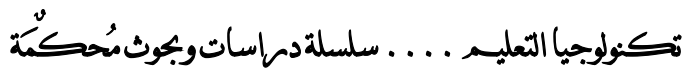


الصـياغة اللغويـة للبنـود الاختباريـة،

تحديد مدى مناسبة مفردات الاختبار

لمستوى طلاب العينة، وقـام الباحثـان

بــإجراء التعـــيلات التــى اقترحهـــا

المحكمـين، والتـى تمثلـت فـى إعـادة

صياغة بعض البنود فقط).

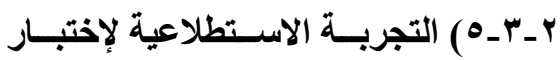

التفكير الابتكاري: تم تطبيق الاختبار

على عينة مكونة من سبعة طلاب من

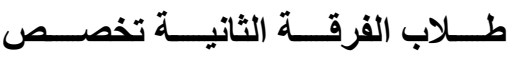

تكنولوجيا تعليم بكلية التربية النوعية جامعة المنوفية بهـف:

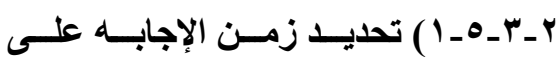

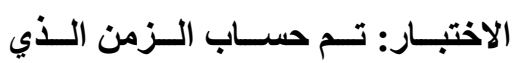

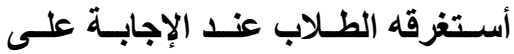

الأسـئلة، وذلــك عـن طريـق حســاب

متوسط زمن الاختبار، وكـان متوسط

الـزمن ( • ") دقيقـة بالنسـبة لأفـراد

المجموعة الاستطلاعية.

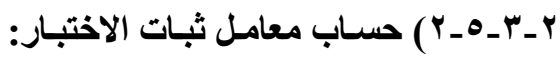

تــم حســاب ثبــات الاختبــار بطريقــة

التجزئة النصفية "لسبيرمان وبراون"

وكـان معامـل ثبات الاختبار التحصيلي

هو (9 ه. • ) وهو معامـل يشير إلى أن

الاختبار على درجة مقبولة من الثبات،
الاعتبـار عند بنـائهم لاختبـار التفكير

الابتكارى الخاص بالبحث الحالي. وقد

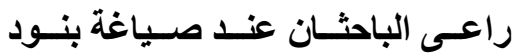

الاختبـار أن (تكون فى صورة لفظيـة،

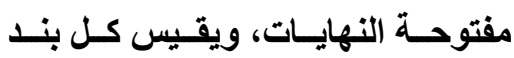

المهـــارات الـثنلاث للتفكيـر الابتكــارى

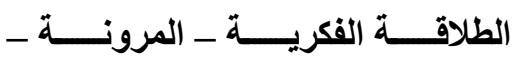

الأصالة).

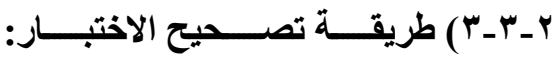

لتصــيح الاختبـار تــم الآتـي (إعـداد

قائمة بالإجابات الخاصة بمحتوى إنتاج

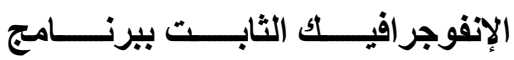

الفوتوشوب، استبعاد الإجابات التى تم

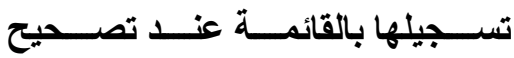

الاختبـــار، اســتبعاد الأفكــار غيـــر

المناسـبة، إعطــاء درجـة لكـل إجابـة

بالنســبة للطلاقـة والمرونــة، إحصــاء

تكرار الإجابات بالنسبة للأصـالة، جمع

درجة كل مهارة للحصول على الدرجة

الكلية للاختبار).

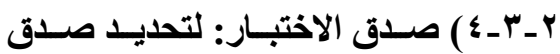

الاختبـار قـام الباحثـان بعرضـه على

مجموعـة مـن المحكمين فـ صـورته

الأوليـة، وذلــك بهـدف (تحديـد مــى

مناسبة بنود الاختبار لقياس ما وضعت

لقياســه، التعـرف علــى مـــى دقــة

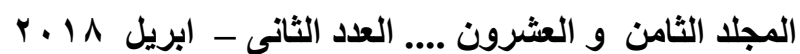


الجمعية المصرية لتكنولوجيا التعليم

الأنثــــة المقدمـــة كــل حســب

مجموعته.

- تطبيق أدوات القياس قبليا: تم التطبيق

القبلي للإختبار التحصيلي لمهارات إنتاج

الإنفوجرافيك الثابت، واختبار التفكير

الابتكاري على عينة البحث قبليًا. وذلك

لقياس ما لدى الطلاب من معلومات حول

موضوع الاراسة وحساب تجانس

المجموعات، ولم يتم تطبيق بطاقة تقييم

المنتج وذلك لأن موضوعات التعلم يارسها

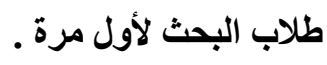

تطبيق مادة المعالجة التجريبية:

ا. . تــم تقسـيم الطـلاب لأربــع مجموعـات

الأولى نمط التلميع المكتوب مع الطلاب

المســقلمون، والثانيــة نمــط التلمـيح

المكتــوب مـــع الطــلاب المعتمــــون،

والثالثة نمط التلميح اللوني ميع الطلاب

المسـتقلون، والرابعـة نمــط التلمـيح

اللوني مع الطلاب المعتمدون.

r. تم شرح التعامل مـع بيئة التعلم النقـال

وكيفية الاخول و التسجيل فيها للطلاب،

وكذلك كيفية رفع التكليفات.

r. تم إرسال الدعوات للطلاب عبر بريـدهم

الإكتروني للاخول على البيئة، وكذلك

إدخال الطلاب في مجموعتهم.
ويغنى ذلك أن الاختبار يمكن أن يعطى

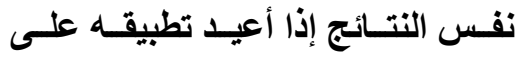
العينة نفسها في نفس الظروف.

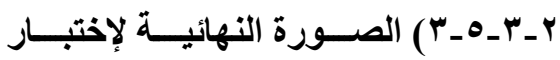

التفكير الابتكاري: أصبح الاختبار فى

صورته النهائية مكوناً من خمسة بنود

اسـتهـف قيــاس التفكيـر الابتكــارى

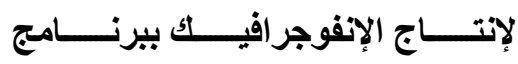

$$
\text { القوتوشوب بملحق ( • (1). }
$$

رابعا: إجراعات التجربة الأساسية

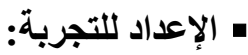

- تم تجهيز مـادة المعالجـة التجريبية

وهي بيئة التعلم النقـال وفقَّا لنمط

$$
\text { التلميحات والأسلوب المعرفي. }
$$

ـ ــــم تهيئـة الطـلاب لتطبيـق الأدوات

علـيهم مـن خـلال عمـل لقـاء بهـم

وإعطـاءوم معلومـات عن موضوع

البحث وأهمية التعلم من خلال بيئة

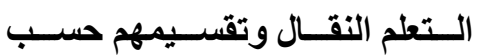

التصــــميم التجريبـــي وأســلـوب

ومتطبات الدراسة.

- تــم التمهيـــ لإجـراء تجربـة البحـث

وإعطاء المطلومـات الخاصـة بالبيئة

وكيفيــة تقـــيم التلميحسـات علـى 
المقرر الموجـود ببيئـة التتعلم النقـال في تبويب الأنشطة والتكليفات.

7. يقوم الطالب بوضع النشـاط كمـا طلب منـه تمامًا من خلال تبويب الأنشطة والتكليفـات كل في رابط الاسم الخاص به وأيضًا يقوم المعلم بإعطاء هم التلميحات المناسبة لهم حسب نمـط التلمسيح المسـتخدم فـي كـل مجموعة.

" تطبيق أدوات البحث بعديًا: تم تطبيق أدوات

البحث بعديًا على طلاب مجموعة البحث

(الاختبار التحصيلي، بطاقة تقييم الأداء المهاري، اختبار التفكير الابتكاري).

ـ استمر التجريب الاستطلاعي والأساسـي للتجربـة في الفصل الار اسـي الثـاني للعسام الجـامعي ؟ 1 ـ ب/ V ا • r م واستغرق التطبيق ستة أسابيع. خامسا: المعالجات الإحصائية

بعـد إتمــام إجـراعات التجربـة الأساسـية

للبحــث، تـم تفريــخ درجـات الطـلاب فـى الاختبـار

التحصـيلى وبطاقـة تقيــيم الأداء واختبـار التفكيـر

الابتكـاري ( قبلبـاً - بعدياً ) فى جداول مُعدة لـللك

تمهيداً لمعالجتها إحصـائياً واستخراج التتائج، وتم

اســتخدام الحزمــة الإحصــائية ال SPSS

$$
\text { المعالجات الإحصائية. }
$$

ع. تم إعطاء طلاب عينة البحث رابط البيئة

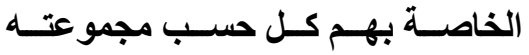

كالتالمي:

المجموعة الأولى

https://sites.google.com/site/infograph ictec1

$$
\text { المجموعة الثانية }
$$

https://sites.google.com/site/infograph ictec2

المجموعة الثالثة

https://sites.google.com/site/infograph ictec3

$$
\text { المجموعة الرابعة }
$$

https://sites.google.com/site/infograph ictec4

ولا يـتم فتح البيئة إلا مـن خـلال الطـلاب الذين

وجه لهم دعوة على البريد الإلكتروني الخـاص بهم

محـددًا فيهـــا دور المــتعلم علــى الموقــع كقــارئ ومشساركين فاعلين في المجموعات، وعليهم قبول الدعوة ومـن ثم يمكنهم زيـارة المحتوى من خـلال بيئة التعلم والتفاعل أيضًا. •. تم تحديد الأنشطة التي يجب على الطالب القيـام بهــا بعـد إطلاعـهـ علـى موديـولات * ملحق (1 1 ) شرح خطوات الاخول إلى بيئة التعلم النقال.

المجلد الثامن و العشرون .... العدد الثانى ـ ابريل 1 1 . r 
الجمعية المصرية لتكنولوجيا التعليم

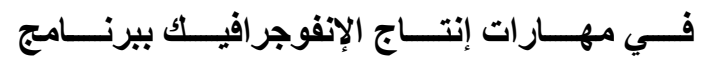
نتائج البحث: الفوتوشـوب نظرًا لأن الطلاب يارسـوا موضوعات الــتعلم لأول مــرة. وذلـــك بحســاب الفـروق بـين مجمـوعتي البحث الأساسيتين (بيئـة التعلم النقـال المدعم بـالتلميح المكتوب/بيئة التعلم النقال المدعم بـالتلميح اللـوني) وكل مجموعـة مـن المجمـوعتين تضم طلاب من النوعين (مستقلون/معتمدون) فيمـا يتطلق بلرجات الاختبار التحصيلي، واختبار التفكير الابتكـاري، وقد تم استخدام الأسلوب الإحصـائي

$$
\text { كما في جدول (r)(T-Test) }
$$

تم عرض التتائج التـي تـم التوصل إليها وتفسـيرها علـى ضــوي فـروض البحـث ونتــائج الار اسـات السـابقة، وتقديم التوصيات و المقترحات الخاصة بموضوع البحث كما يلي:

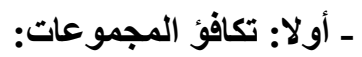
تمم تحليل نتـائج كل مسن الاختبـار التحصيلي واختبار التفكير الابتكاري قبليا، وذلك بهدف التعرف علـى مـدى تجـانس المجموعـات قبـل التجربــة الأساسية، ولم يطبق الباحثان بطاقة تقييم الطلاب جدول (ץ) نتائج اختبار ليفين و"ت" بين مجموعتي البحث للاختبار التحصيلي واختبار التفكير الابتكاري في التطبيق القبلي

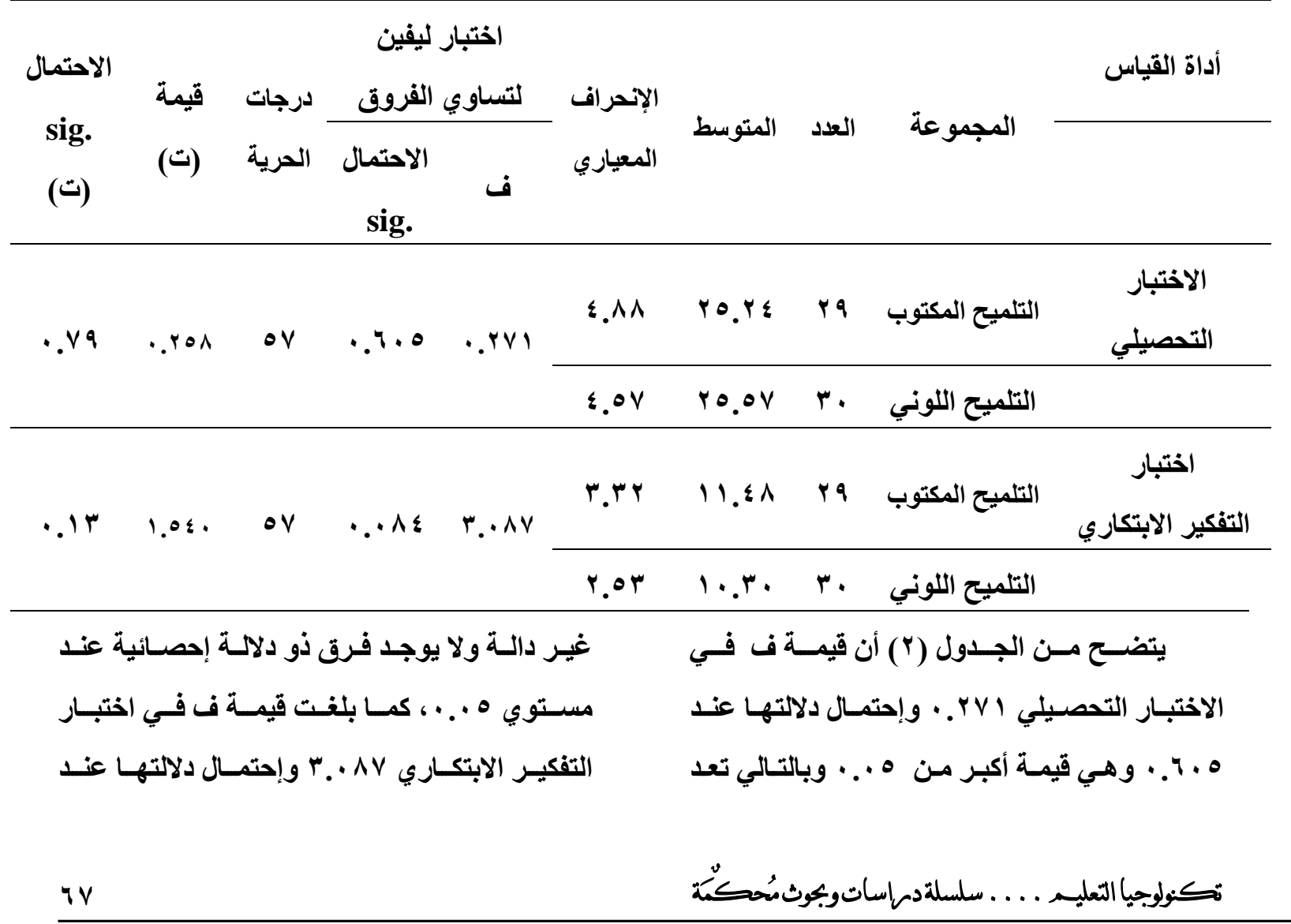


الجمعية المصرية لتكنولوجيا التعليم

وللإجابـة عن السـؤال الثاني وينص على " مـا

معسايير تصسميم بيأسـة التتعلم النقـال فـي ضسوع نمـط التلميحـات (المكتوبة/اللونبــة) والأســلوب المعرفـي (المعتمد/المستقل)؟" وتمت الإجابـة على هذا السؤال في الإطار النظري للبحث والإجراءات حيث تم التوصل إلي قائمـة معايير تصميم بيئة التعلم النقال في ضوى نمـط التلميحـات (المكتوبة/اللونيـة) وهـي مكونـة مسن ثلاثنة عشـر معيـارًا أساسـيًا وكل معيـار يثـتمل على يلى مجموعة من المؤشرات. بملحق (•) وللإجابة عن السؤال الثالث وينص على " مـا التصميم التعليمسي لبيئة التعلم التقال في ضوء نمط التلميحـات (المكتوبة/اللونيـة) والأسـلوب المعرفي (المعتمد/المســــتقل) لتتميـــــة مهـــــــار ات إنتــــــاج الإنفوجرافيك الثابـت باسـتخدام برنـامج الفوتوشـوب والتفكير الابتكـاري بمقرر إنتـاج الرسـوم التعليميـة لاى طلاب الفرقة الثانيـة تخصص تكنولوجيا التعليم ؟"، وتمــت الإجابـة علـى هــا الســؤال فـي جـزء الإجراءات حيث تبنى الباحثان نموذج نموذج محمد

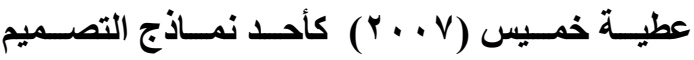
التعليمي.

وللإجابــة عـن الســؤال الرابــع، الخــامس

والسـادس وينصـوا على " (مسا أثر نمـط التلميحـات المكتوبة/اللونيــة؟، مــــا أثــــر الأســلوب المعرفــي المعتمد/المستقل؟، ما أثر التفاعل بين نمط التلميحات

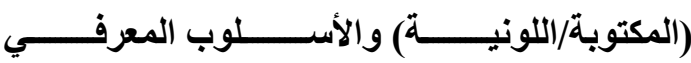
(المعتمد/المستقل)ج) بيئـة التعلم التقـال على تتميـة
ع ^ • . • وهـي قيمـة أكبر مـن ه . . • وبالتـالي تعــ غيـر دالـة ولا يوجـد فرق ذو دلالـة إحصـائية عنــ مستوي ه •. •، مما يشير إلي تجـانس المجموعتين قبل البدء في إجراء التجربة وأن أي فرق يحدث بعد التجربـة يرجـع إلـي اختـلاف المتغيـرات المسـتمة بالبحــث ولــيس إلــي اختلافــات موجــودة بــين المجموعتين قبل إجراء التجربة، وهو شرط اختبار ت للعينات المستقلة كمـا نجد أن قيمـة ت المحسوبة للاختبار التحصيلي ^هץ. . و وإحتمـال دلالتها و \. . وهـي أكبر مـن ه •. . ، وأيضًا قيمسة ت المحسوبة لإختبار التفكير الابتكاري • ع هـ و إحتمـال دلالتها r ا. • وهـي أكبر مـن ه . . ، إذا لا يوجد فرق ذو دلالة احصائية بين طلاب المجموعتين في الاختبار التحصيلي واختبـار التفكيـر الابتكـاري في القيـاس القبلي مما يؤكد وجود تكافؤ بين المجموعثين. ـ ثانيا: عرض النتائج الخاصة بأسئلة البحث: للإجابـة عـن السـؤال الأول ويـنص علـى " مــا مهارات إنتاج الإنفوجرافيك الثابت باستخدام برنـامج الفوتوشوب بمقرر إنتاج الرسوم التعليمية لدى طلاب الفرقة الثانية تخصص تكنولوجيا التعليم؟" وذلك من خـلال التوصـل إلى قائمسة بالمهـارات اللازمسة لإنتـاج الإنفوجرافيـك الثابـت بإســخدام الفوتوشـوب لطـلاب الفرقة الثانية تكنولوجيا التعليم واشتملت على أربع مهارات رئيسة يندرج منها ع ب مهارة فرعية. بملحق

المجلا الثامن و العشرون .... العدد الثانى ـ ابريل 1 1 . r 
الجمعية المصرية لتكنولوجيا التطليم

النقال."، والفرض الثاني على أنه " لا يوجد فرق

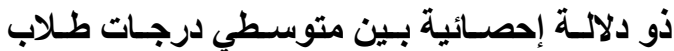
المجمسوعتين التجـريبيتين فـي اختبـار التحصـيل الاراسـي للتطبيق البعدي يرجيع إلى أثر اختلاف

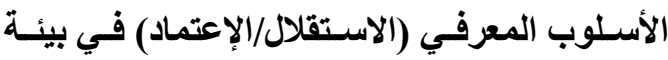
التعلم النقال."، والفرض الثالث على أنسه "توجد

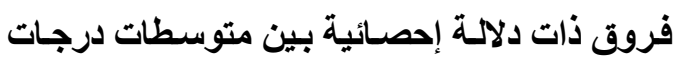
طـلاب المجموعـات التجريبيـة الأربـع فـي اختبـار التحصيل الدراسي للتطبيق البعدي ترجيع إلى أثر التفاعـل بـين نمــ التلميحـات (المكتوبة/اللونيـة) والأسـلوب المعرفي (الاستقلال/الإعتماد) في بيئسة التعلم النقال." وللتحقق من صحة الفروض الثلاثة تــم اســــام نتــائج التطبيـق البعـــي للأختبـار التحصيلي لطلاب المجموعـات الأربع وتم حسـاب

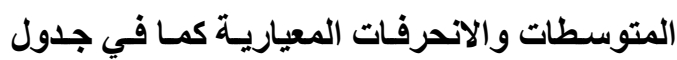

كـل مـن: (الجوانـب المعرفيـة، الجوانـب الأدائيـة لمهارات إنتاج الإنفوجر افيك الثابت باستخدام برنـامج الفوتوشـوب، والتفكيـر الابتكــاري) بمقـرر إنتــــاج

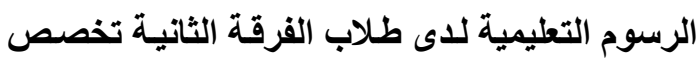
تكنولوجيا التعليم؟" وتمت الإجابة عن هذه الأسئلة من خلال التحقق من صحة فروض البحث من خلال إجراء المعالجـات الإحصـائية على البيانـات التـي تـم التوصل إليها من خلال التجربة الأساسية للبحث كمـا يلي: - nen الفرض الأول والثاني والثالث: ينص الفرض الأول على أنه: "لا يوجد فرق ذو

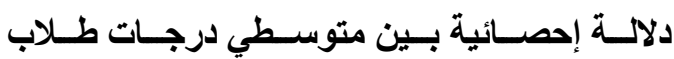
المجمـوعتين التجـريبيتين فـي اختبـار التحصـيل الاراسـي للتطبيق البعدي يرجـع إلى أثر اختلاف

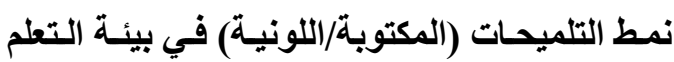
جدول (r) المتوسطات والاتحرافات المعيارية لدرجات الاختبار التحصيلي

\begin{tabular}{|c|c|c|c|c|}
\hline الإتحراف المعياري & المتوسط & العدد & الأسلوب المعرفي & نمط التلميحات \\
\hline Y. $\leqslant \varepsilon$ & $19.1 \mathrm{~V}$ & ir & مستقل & المكتوب \\
\hline $1 . \wedge \varepsilon$ & 90.04 & iv & معتمد & \\
\hline r.^. & ar.q. & rq & مجموع & \\
\hline 1.79 & & 11 & مستقل & اللوني \\
\hline r.ru & 91.11 & 19 & معتمد & \\
\hline$\varepsilon . r q$ & $\Lambda \Lambda . Y \vee$ & $r$. & المجموع & \\
\hline$r .71$ & ᄉ .. q & $r r$ & مستقل & المجموع \\
\hline$r . \cdot r$ & 94.19 & rq & معتمد & \\
\hline$\varepsilon .70$ & $9 . .0 \leq$ & $0 q$ & المجموع & \\
\hline
\end{tabular}




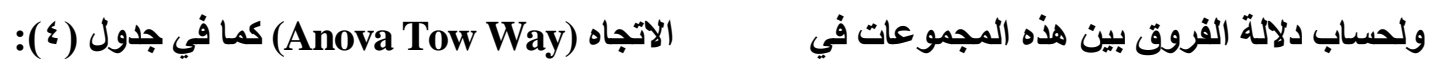
الاختبار التحصيلي تم استخدام تحليل التباين ثنائي جدول (0) نتائج تحليل التباين ثنائي الاتجاه للإختبار التحصيلي في التطبيق البعدي

\begin{tabular}{|c|c|c|c|c|c|c|}
\hline مستوى الالاكة عند & 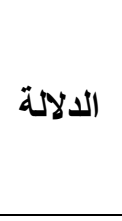 & قيمة (ف) & متوسط المربعات & لدرجات & المربعات & مصدر التباين \\
\hline 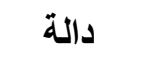 & $\because \cdots$ & $\Lambda \varepsilon . \Delta Y$. & r.4.1.0 & 1 & r.7.1.0 & نمط التلميحات \\
\hline 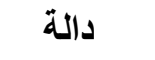 & $\because \cdots$ & $17 . .201$ & $997 . r \cdot V$ & 1 & $997 . r \cdot V$ & الأسوب المعرفي \\
\hline \multirow[t]{3}{*}{ غير دالة } & $\because r r \cdot$ & 1.047 & 7.700 & 1 & 7.700 & نمط التلميحات × الأسلوب المعرفي \\
\hline & & & ( & $\Delta 0$ & rrA.rrV & الخطأ \\
\hline & & & & 09 & $\leq \wedge \leq q \Gamma \leq . \cdot$ & 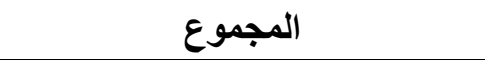 \\
\hline
\end{tabular}

- بالنسبة للأسلوب المعرفي (مستقل/معتمد) على

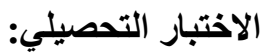

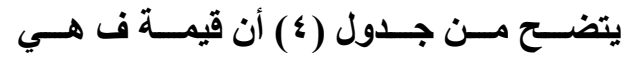

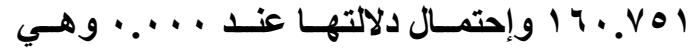
قيمـة أقل مـن مستوي الدلالـة ه . .. وبالتـالي تعد دالة ويوجد فرق دال إحصائيا عند مستوي ه هـ. في الاختبار التحصيلي، ولتحديد اتجـاه هذا الفرق مـن جدول (rّ) يتضـح أن الفرق بين المجموعتين لصالح المجموعة التجريبية ذات الأسلوب المعرفي المعتمد وكان متوسطها هو 9 ا.ب 9 وهو أكبر من النون متوسط المجموعة التجريبية ذات الأسلوب المعرفي

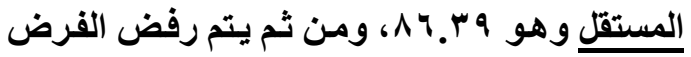
الصفري وقبول الفرض البديل، مما يشير إلى وجود فرق دال إحصائيًا بين المجموعتين التجريبيتين في البي الاختبار التحصيلي لصالح المجموعة التجريبية ذات لهنيل الأسلوب المعرفى المعتمد.
ـ بالنسـبة لـنمط التلميحـات (مكتوبة//لونيـة) على لهـ

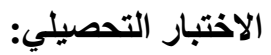

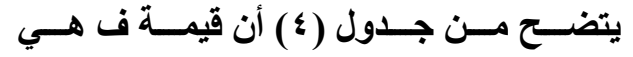

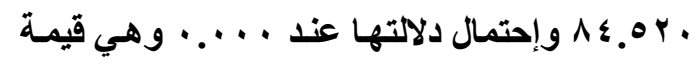

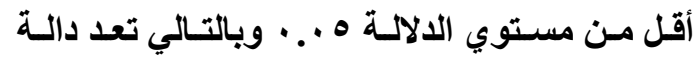
ويوجد فرق دال إحصـائيا عند مستوي ه •. • في الاختبار التحصيلي، ولتحديد اتجـاه هذا الفرق من جلول ("آ) يتضح أن الفرق بين المجموعتين لصالح المجموعة التجريبية التي قدم لها تلميحات مكتوبـة وكان متوسطها هو ، 9.99 وهو أكبر من متوسط المجموعـة التجريبيـة التي قدم لها تلميحـات لونيـة وهو VA. Y V ومن ثم يتم رفض القرض الصفري وقبول الفرض البديل، مما يشير إلى وجود فرق دال إحصائيًا بين المجموعتين التجريبيتين في الاختبار التحصيلي لصالح المجموعة التجريبية التي قدم لهابيا تلميحات مكتوبة. 
التلميحــات (المكتوبة/اللونيـة) فــي بيئـة الـتـلم النقـال."، والفـرض الخـامس على أنـه " لا يوجــ فرق ذو دلالة إحصائية بين متوسطي درجات طلاب المجمـوعتين التجريبيتين في بطاقـة تقيـيم الأداء

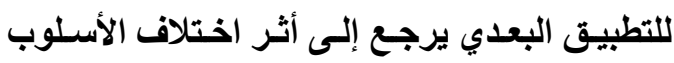

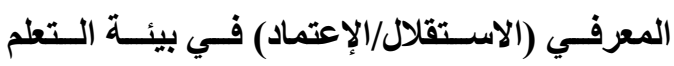
النقال."، والفرض السادس على أنه "توجد فروق

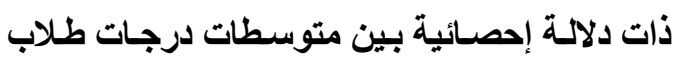
المجموعات التجريبية الأربع في بطاقة تقييم الأداء

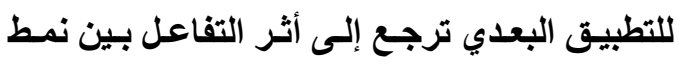
التلميحـات (المكتوبة/اللونيـة) والأسـلوب المعرفي لتري (الاســتقلال/الإعتماد) فــي بيــــة الـتـعلم النقــال. " وللتحقق مـن صـحة الفروض الثلاثـة تم استخدام نتائج التطبيتق البعدي لبطاقـة تقيـيم الأداء لطـلاب

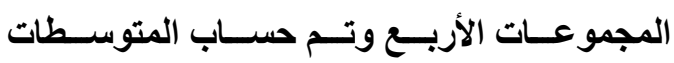
والانحرفات المعيارية كما في جدول (•):
ـ بالنســـبة للتفاعــل بــين نمــــ التلميحــــات

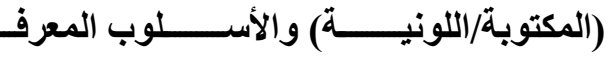
(المستقل/المعتمد) على الاختبار التحصيلي: يتضـح مسن جـدول (؛ ) أن قيمسة ف هـي

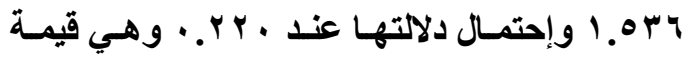

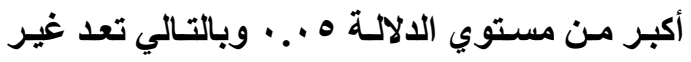

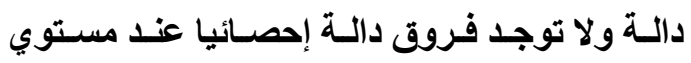
ه . . • في الاختبـار التحصـيلي، إذا لا يوجد تـأثير

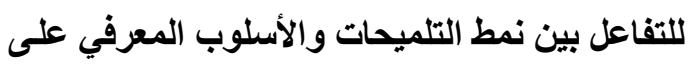

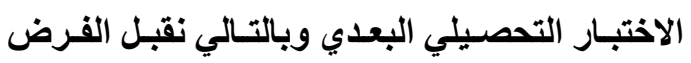
الصفري ونرفض البديل. الفرض الرابع والخامس والسادس: ينص الفرض الرابع على أنها: " لا يوجد فرق

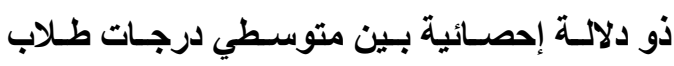
المجمـوعتين التجريبيتين في بطاقـة تقيـيم الأداء

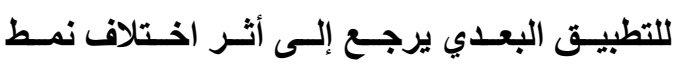
جدول (0) المتوسطات والاتحر افات المعيارية لارجات بطاقة تقييم الأداء

\begin{tabular}{|c|c|c|c|c|}
\hline الإنحراف المعياري & المتوسط & 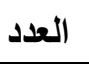 & الأسلوب المعرفي & نمط التلميحات \\
\hline $1 . r$. & $\varepsilon r . \wedge r$ & Ir & مستقل & المكتوب \\
\hline 1.91 & $\leqslant ५ . \vee ५$ & iv & معتمد & \\
\hline $1 . \Lambda \cdot \varepsilon$ & $\leqslant 0.00$ & rq & مجموع & \\
\hline I.VYr & $\varepsilon \cdot . \wedge r$ & 11 & مستقل & اللوني \\
\hline $1.70 r$ & $\{1 . M$ & 19 & معتمد & \\
\hline 1.79. & $\leq 1 . \cdot v$ & $r$. & المجموع & \\
\hline Y..9I & $\varepsilon r . r q$ & $r r$ & مستقل & \\
\hline r.l $\leq$. & $\varepsilon r . \wedge r$ & rq & معتمد & المجموع \\
\hline Y.A $\varepsilon$. & $\varepsilon r . r V$ & $\Delta q$ & مجموع & \\
\hline
\end{tabular}


الاتجاه (Anova Tow Way) كما في جدول (7): ولحساب دلالة الفروق بين هذه المجموعات لبطاقة تقييم الأداء تم استخدام تحليل التباين ثنائي جدول (†) نتائج تحليل التباين ثنائي الاتجاه لبطاقة تقييم الأداء في التطبيق البعدي

\begin{tabular}{|c|c|c|c|c|c|c|}
\hline مستوى ه الدلالة عند & 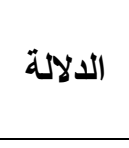 & قيمة (ف) & متوسط المربعات & الحرجية & مجموع المربعات & مصدر التباين \\
\hline 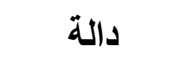 & $\because \cdots$ & $1 r q . \wedge$. & rOV.Pr & 1 & rOV. Pr & نمط التلميحات \\
\hline 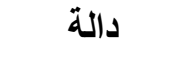 & $\because \cdots$ & $19 .\{1 \wedge$ & rs.77V & 1 & rی.77V & الأسوب المعرفي \\
\hline \multirow[t]{3}{*}{ دالة } & $\because \cdots 1$ & 11.rur & rr.0Yo & 1 & rr.oro & نمط التلميحات × الأسلوب المعرفي \\
\hline & & & 1.991 & $\Delta 0$ & $1.9 .0 Y$. & الخطأ \\
\hline & & & & 09 & 11.949. & المجموع \\
\hline
\end{tabular}

ـ بالنسبة للأسلوب المعرفي (مستقل/معتمد) لبطاقة تقييم الأداء:

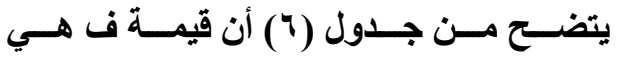

1 19.9 أو وإحتمال دلالتها عند . .... وهي قيمـة

أقل مـن مسـتوي الدلالـة هـ ه. . • وبالتـالي تعد دالـة ويوجد فرق دال إحصائيا عند مستوي ه •. • لبطاقة تقييم الأداء، ولتحديد اتجـاه هذا الفرق من جدول (0) يتضــح أن الفــرق بـين المجــوعتين لصــالح المجموعة التجريبية ذات الأسلوب المعرفى المعتمد

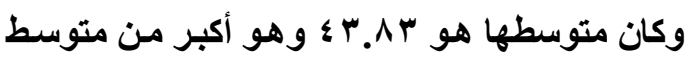
المجموعــة التجريبيـــة ذات الأســلـوب المعرفـــي

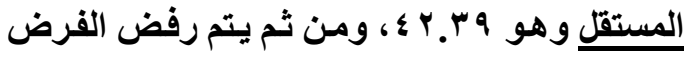
الصفري وقبول الفرض البديل، مما يشير إلى وجود فرق دال إحصائيًا بين المجموعتين التجريبيتين في بطاقة تقييم الأداء لصـالح المجموعة التجريبية ذات الأسلوب المعرفى المعتمد.
ـ بالنسبة لنمط التلميحات (المكتوبة/اللونية) لبطاقة تقييم الأداء:

يتضــح مـن جـدول (†) أن قيمــة ف هــي

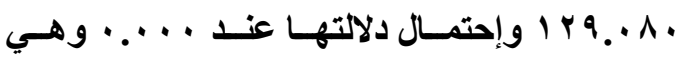
قيمـة أقل مـن مستوي الدلالـة هـ . . • وبالتـالي تعد دالـة ويوجد فرق دال إحصـائيا عند مستوي ه •.. لبطاقة تقيـيم الأداء، ولتحديد اتجـاه هذا الفرق من جدول (0) يتضح أن الفرق بين المجموعتين لصالح المجموعة التجريبية التي قدم لها تلميحـات مكتوبـة وكان متوسطها هو 0.0 0 ؛ وهو أكبر من متوسط المجموعة التجريبيـة التي قدم لها تلميحـات لونيـة وهو V • ـ أع، ومن ثم يتم رفض الفرض الصفري وقبول الفرض البديل، مما يشير إلى وجود فرق دال إحصـائيًا بين المجمـوعتين التجريبيتين في بطاقة تقييم الأداء لصـالح المجموعـة التجريبيـة التي قدم لها تلميحات مكتوبة.

المجلد الثامن و العثرون .... العدد الثانى ـ ابريل 1 1 ـ ץ 
الجمعية المصرية لتكنولوجيا التعليم

البعـــي وبالتـــالي نقبـلـل الفـرض البـديل ونــرفض الصفري. ممـا يشير إلى وجود فروق دالة إحصـائيًا للتفاعل بين نمط التلميحات والأسوب المعرفي بين المجموعات التجريبية الأربع، ولتحديد اتجاه الفروق بـين المتوسـطات اســتخدم الباحـث اختبـار شـيفيه للمقارنـات المتعددة، ويوضـح جدول (V) المقارنـات المتعددة بين المجموعات فيما يتعلق بلأداء المهاري:
ـ بالنســـبة للتفاعــل بــين نمــــ التلميحــــات

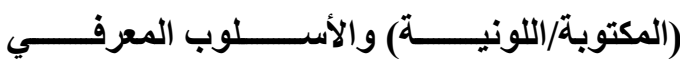
(المستقل/المعتمد) لبطاقة تقييم الأداء:

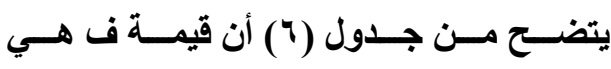

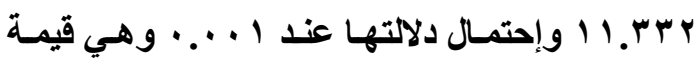
أقـل مـن مسـتوي الدلالـة هـ ... وبالتـالي تعـد دالـة

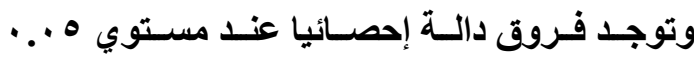
لبطاقة تقييم الأداء. إذا يوجد تأثير للتفاعل بين نمط التلميحـات والأسلوب المعرفي على الأداء المهاري

جدول (V) نتائج المقارنات المتعددة للتفاعل بين نمطي التلميحات والأسلوب المعرفي فيما يتعلق بلأداء المهاري

\begin{tabular}{|c|c|c|c|c|c|}
\hline تلميح لوني+ & تلميح لوني+ & تلميح مكتوب+ & تلميح مكتوب+ & المتوسط & المجموعة \\
\hline - & - & - & & $\varepsilon r . \wedge r$ & تلميح مكتوب+ مستقل \\
\hline- & - & & •..... & $\leq 7 . \vee 7$ & تلميح مكتوب+ معتمد \\
\hline- & & •.... & • . . . . دال & $\varepsilon \cdot . \wedge r$ & تلميح لوني+ مستقل \\
\hline & • 1 . • غير دال & •..... & • ... • . . دال & $\leqslant 1 . Y_{1}$ & تلميح لوني+ معتمد \\
\hline
\end{tabular}

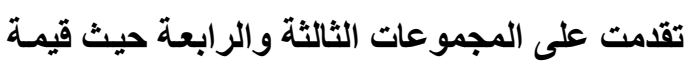

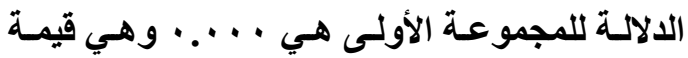
دالة عند مستوى دلالمة ه .. . ومتوسط المجموعة فئة الأولى هو r^. r؟ بالمقارنة بمتوسطات المجموعة

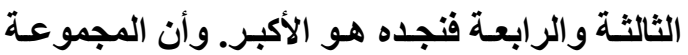
الثالثـة التـي اسـتخدمت نمـط التلميحسات اللـوني+ أسـلوب الأستقلال المعرفي تسـاوت مـع المجموعـة

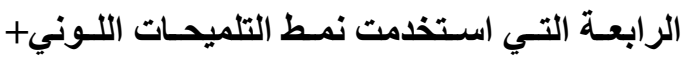
أسـلوب الاعتمـاد المعرفي حيث قيمـة الدلالـة هـي

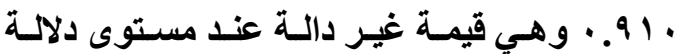

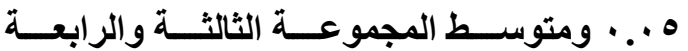

يتضـح مـن جـدول (V) للمقارنـات المتعـدادة للتفاعل بين نمطي التلميحسات والأسلوب المعرفي فيمـا يتعلق بـالأداء المهـاري أن المجموعـة الثانيـة التي استخدمت نمط التلميحـات المكتوب+ أسلوب الأستقلال المعرفي تقدمت على المجموعات الثلاثة الأخرى حيث قيمـة الدلالـة للمجموعـة الثانيـة هـي |.... ومتوسط المجموعة الثانيـة هو بـــ ؛ بالمقارنـة بمتوسطات المجموعات الأخرى فنجده هو الأكبر،

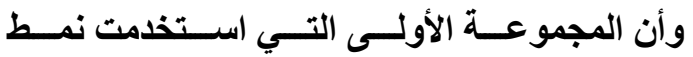
التلميحـات المكتـوب+ أسـلوب الاعتمــاد المعرفي الاوني

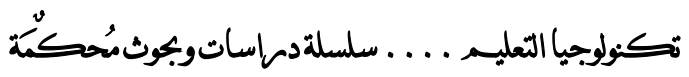


النقال."، والفرض الثامن على أنها " لا يوجد فرق

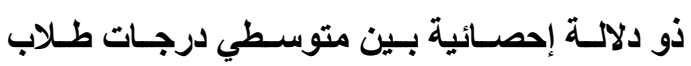

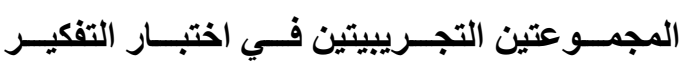
الابتكاري للتطبيق البعدي يرجـع إلى أثر اختلاف

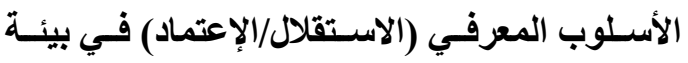

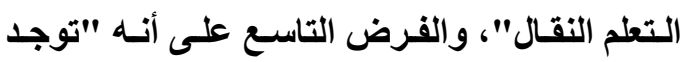
فروق ذات دلالـة إحصـائية بين متوسطات درجسات طـلاب المجموعـات التجريبيـة الأربـع فـي اختبـار التفكير الابتكاري البعدي ترجع إلى أثر التفاعل بين

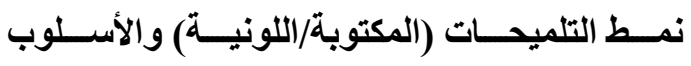
المعرفـي (الاســتقلال/الإعتماد) فــي بيــــة الــتملم

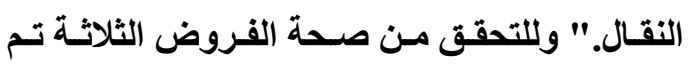
اسـتخدام نتـائج التطبيـق البعـدي لإختبـار التفكيـر

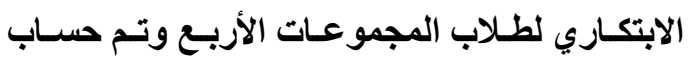
المتوسطات والاتحرفـات المعياريـة كمـا في جدول

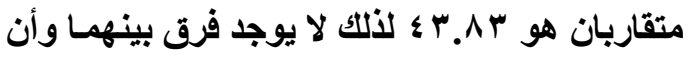

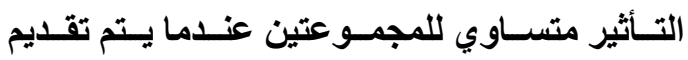
التلميحات اللونية لهما. ولتحديد مدى تأثير المتغير المستقل على المتغير التابع تم حساب (إيتا تربيع)

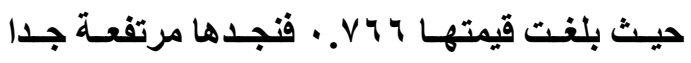

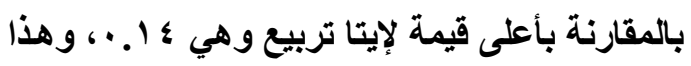

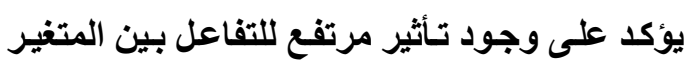

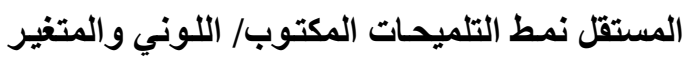
التصــنيفي الأســلـوب المعرفــي الأســقلال مقابـل الاعتماد على المتغير التابع وهو الأداء المهاري. الفرض السابع والثامن والتاسع: ينص الفرض السابع على أنه: "لا يوجد فرق

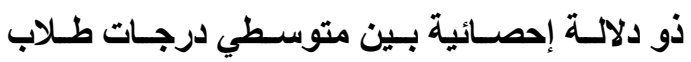

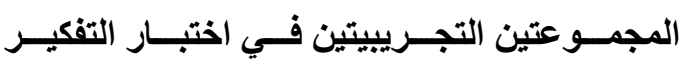
الابتكـاري للتطبيتق البعدي يرجـع إلى أثر اختلاف

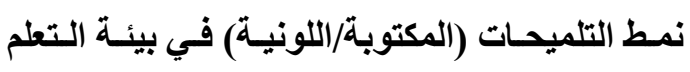

\begin{tabular}{|c|c|c|c|c|}
\hline الإنحراف المعياري & المتوسط & العدد & الأسلوب المعرفي & نمط التلميحات \\
\hline r. $\{r q$ & $\varepsilon r .4 r$ & ir & مستقل & المكتوب \\
\hline 1.101 & $\leq r . Y \leq$ & IV & معتمد & \\
\hline 1.290 & \& & rq & مجموع & \\
\hline $1 . \wedge 7 \wedge$ & $\leqslant 1.91$ & 11 & مستقل & اللوني \\
\hline 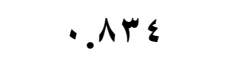 & $\varepsilon r . \wedge \varepsilon$ & 19 & معتمد & \\
\hline $1 . r 01$ & $\leq r .0$ & $r$. & المجموع & \\
\hline r.YYo & $\varepsilon r . v$. & rr & مستقل & \\
\hline$r .00$ & $\varepsilon r . \cdot r$ & rq & معتمد & المجموع \\
\hline r.7rq & $\leq r . q$. & $0 q$ & مجموع & \\
\hline
\end{tabular}


الجمعية المصرية لتكنولوجيا التعليم

ثنائي الاتجاه (Anova Tow Way) كما في جدول

ولحساب دلالة الفروق بين هذه المجموعات

$:(9)$

لاختبار التفكير الابتكاري تم استخدام تحليل التباين

جدول (9) نتائج تحليل التباين ثنائي الاتجاه لاختبار التفكير الابتكاري في التطبيق البعدي

\begin{tabular}{|c|c|c|c|c|c|c|}
\hline مستوى ه •. الدلالة عند & 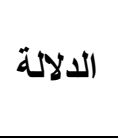 & قيمة (ف) & المربعات & الحرية & مجموع المربعات & مصدر التباين \\
\hline 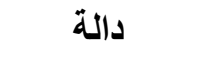 & $\because r \wedge$ & 0.94 & $1 Y .7 \leq 7$ & 1 & $1 Y .7 \leq 7$ & نمط التلميحات \\
\hline غير دالة & $\cdot$ rVA &.$v a r$ & $1.9 \vee v$ & 1 & $1.9 \vee V$ & الأسوب المعرفي \\
\hline \multirow[t]{3}{*}{ غير دالة } & .9194 & $1 . v \varepsilon$ & $\varepsilon . r \leqslant V$ & 1 & $\varepsilon . r \leqslant V$ & نمط التلميحات × الأسلوب المعرفي \\
\hline & & & r. $\leqslant q$. & $\Delta 0$ & $\mid r v . \leq 11$ & الخطأ \\
\hline & & & & $\Delta q$ & 1. 1 rरq. & 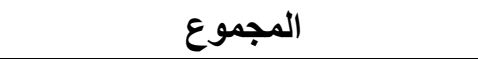 \\
\hline
\end{tabular}

- بالنســبة لــنمط التلميحــات (المكتوبة/اللونيــة)

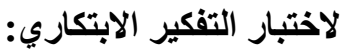

- بالنسبة للأسلوب المعرفي (مستقل/معتمد) لاختبار

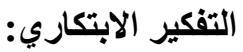

يتضح من جدول (9) أن قيمة ف هي Y Y V9.

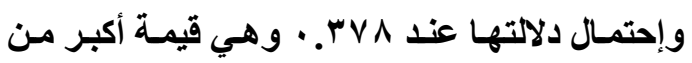

مستوي الدلالـة ه .. . وبالتـالي تعد غير دالـة ولا

يوجد فرق دال إحصائيا عند مستوي ه ... لاختبار

التفكير الابتكـاري، ممـا يشير إلى عدم وجود فرق

دال إحصــائيًا بـين المجمـوعتين التجـريبيتين، إذا لا

يوجد تأثير للأسلوب المعرفي على اختبار التفكير

الابتكاري وبالتـالي نقبل الفرض الصفري ونرفض

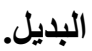

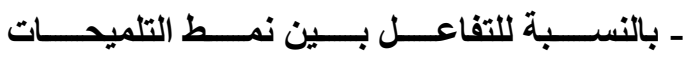

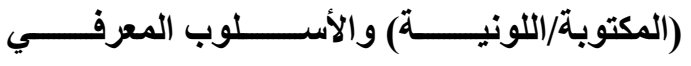

(المستقل/المعتمد) لاختبار التفكير الابتكاري:
يتضح من جدول (9) أن قيمة ف هي r 7 +.

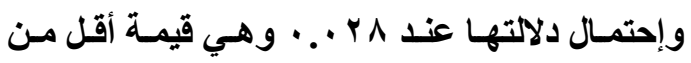

مستوي الدلالة ه . . • ويالتالي تعد دالة ويوجد فرق دال إحصـائيا عنــ مستـوي ه .. • لاختبـار التفكير

الابتكاري، ولتحديد اتجاه هذا الفرق من جدول (^) يتضح أن الفرق بين المجموعتين لصالح المجموعة التجريبيـة التـي قـدم لهـا تلميحـات مكتوبــة وكـان متوسـطها هـو اس.ب ؛ وهـو أكبـر مسن متوسـط المجموعة التجريبيـة التي قدم لها تلميحات لونيـة وهو · ه. ب ؛ ، ومن ثم يتم رفض الفرض الصفري وقبول الفرض البديل، مما يشير إلى وجود فرق دال إحصـائيًا بين المجموعتين التجريبيتين في اختبار التفكير الابتكاري لصسالح المجموعة التجريبية التي قدم لها تلميحات مكتوبة. 
الجمعية المصرية لتكنولوجيا التعليم

التلميحات اللونيـة في التعلم النقال وقد يرجع ذلتك لأن التلميحـات المكتوبــهـ يــــــهـا الطـلاب بطريقــة سـريعة لمــا يجـب أن يتعلمـوه بخــلاف التلميحسات اللونيـة فعملت على تثتتيت انتبـاه الطلاب وخاصـة مـع المحتوى المقدم وهو تعلهـه كيفية إتقان إنتـاج الإنفوجر افيـك التعليمس، وأيضًا طبيعـة بيئة التعلم النقال مـن حيث التجول الحر للمتعلمين ممـا يعمل على تثتتيت انبـاهم أيضًا لذلكت سـاعدت التلميحـات المكتوبه على توجيههم نحو المحتوى المراد تعلمه. ويمكـن تفسـير ذلــك على أسـاس مبـادى النظرية البنائية بحيث أن المتعلم يتعلم أكثر عندما يقـام لـه تلميحـات وإرشـادات ومســاعدات واضـحة لتيسر عليه تركيز انتباهـه نحو المحتوى المطلوب دراسته، وهذا مـا أثـارت إليهه نتائج البحث الحسالي مسن حيــث أن التلميحــات المكتوبــة أفضـلـل مـن التلميحات اللونية لرفع المستوى التحصيلي للطلاب نظرًا لسرعة فهمها من الطلاب عن اللونية، وهذا يتماشـى مـع نظريـة معالجـة المعلومـات حيث تركز هـذه النظريـهـ على العمليـات التـي يجريهــا الفـرد لمعالجــة المعلومــات التــي يسـتقبلها مـن العـالم الخارجي وهي التلميحات. فالتلميحات وفقَا لنظريـة معالجة المعلومـات تعد معالجة لإثارة وجذب انتباه المـتـلم؛ ليتفاعـل مــع موضـوعات الـتعلم، حتـى يستطيع اكتسـاب المعلومـات المطلويسة في النهايـة، وأكدت نظريـة الترميز الثنـائي على نتيجـة البحث الحالي من حيث أن التلميحات المكتوبـه تتبع النظام
يتضـح مسن جـدول (9) أن قيمسة فـ هـي

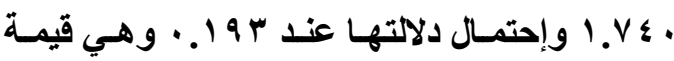
أكبر مـن مستوي الدلالـة ه . .. ويالتـالي تعد غير دالـة ولا توجد فروق دالـة إحصسائيا عنــ مستوي ه .. • في اختبـار التفكيـر الابتكــــ، إذا لا يوجـــ تـأثير للتفاعـل بـين نمـط التلميحـات والأســلوب المعرفـي علـى اختبـار التفكيـر إبتكــاري البعـدي وبالتالي نقبل الفرض الصفري ونرفض البديل.

\section{تفسير ومنـاقشة نتائج البمث:} ـ تفسير النتائج المرتبطة بالتحصيل الدراسي بيئة التعلم النقال على التحصيل الدراسي: وفقـا لنتـائج الفـرض الأول و الــي تـم رفضـه وقبـول الفـرض البـديل وهـو "يوجـ فـرق ذو دلالــة إحصـائية بين متوسطي درجـات طلاب المجموعتين التجريبيتين في اختبـار التحصيل الدراسـي للنطبيق البعـدي يرجـع إلـى أثـر اخـتلاف نمـــ التلميحسات (المكتوبة/اللونيـة) فــي بيئسة الـتـعلم النقـال لصـالح المجموعة التجريبية التي قام لها تلميحـات مكتوبـة"، ممسا يثسير إلـى تقدمها في التحصيل الدراسـي عن المجموعة التي قدم لها تلميحات لونية. وهذا يعني أن التلميحات المكتوبة أدت إلى تنمية التحصيل الدراسي للطلاب وذلك من خلال بيئة التعلم النقال. ترجع هذه النتيجة إلـي أن التلميحات المكتوبـة للتحصيل الدراسي تكون إفادتها للمتعلمين أكثر من 
الجمعية المصرية لتكنولوجيا التعليم

اللغة الإنجليزية ورفع التحصيل الدراسي من خلال بيئة تعلم عبر الويب.

كمـا اختلفت نتيجـة هـا الفـرض مـع نتـائج

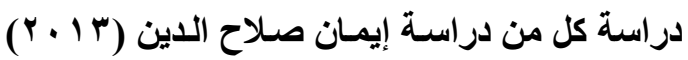
التي توصلت نتائجهـا أنسه لا يوجد فرق في تـأثير اختلاف نمط التلميحـات فلهمـا نفس درجـة التأثير على رفـع وتحفيـز المتعلمـين نحـو عمليـة الـتعلم وخاصة عند التحصيل الدراسي؛ ودراسـة ليو، لين، وياس Liu, Lin, and Paas (2013) على فاعلية التلميحات البصرية بالأسهم والخطوط بحيث لهمسا نفس التأثير على تحسـين التعليم مسن خـلال بيئـات الـتـطلم النقالــة؛ دراســة عبــــالله مســيعيد

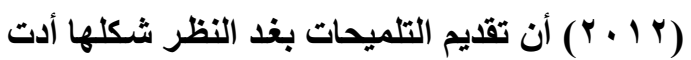
إلسى تحسـين التحصسيل الفـوري و المرجـأ للمفـاهيم الرياضية؛ دراسة شيرين سعد (11 + ץ) التي أكدت على فاعلية نمط التلميح اللوني على زيـادة تحصيل الطلاب؛ ودراسة حنان عبد الله ( • • ץ) أن فاعلية التلمسيح اللـوني على زيـادة تحصسيل الطـلاب هـو الأفضل؛ ودراسة هشـام الثحات (^ . . ץ أن شكل التلميحـات المجسـمة أكثـر فاعليـة علـى تحفيـز المتعلمين نحو عملية التعلم ممـا سـاعد على رفع التحصيل لـدى الطلاب ؛ ودراسـة نهى عبد الحكـ

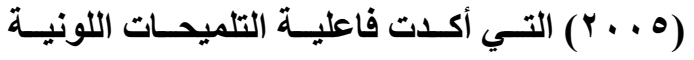
للنصوص فقط حيث أظهرت أعلى كفاعة في تنمية

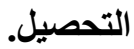

اللفظي وتعالج المعلومات اللفظية ويقوم هذا النظام بتوليد الكلام للكائنـات اللفظية، وتنظيمها في شكل ترابطات هرميـة، وهذا يحتاجـه التحصيل المعرفي نظرًا للكم النظري الذي يميزه بخـلاف التلميحـات اللونية التي كان أثرها ضعيقًا على زيادته. حيث اتفقت هذه النتيجة مـع نتائج عديد من البحوث والاراسـات التي أكلات أن تقديم التلميحـات المكتوبـه هـي الأنسب في رفع التحصيل الدراسـي لدى المتعلمـين مثل دراسـة يـانج (2016) Yang التي أكدت أن التلميحات المكتوبة ساعدت في خفض الحمـل المعرفي وزيــادة نسـبة التحصسيل؛ دراسـة

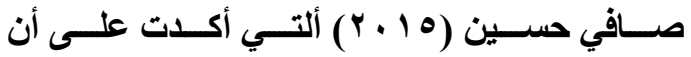
التميحات المكتوبه لها أثرًا فعالَا في تنميـة التحصيل الاراســي لـــى المتعــين؛ دراسـة بوشـيكس، لــو Bوتري، وجروف Boucheix, Lowe Putri, برe and Groff，(2013) التلميحات بالرسوم المتحركة مع النص المكتوب في القدرة على خفض الحمل المعرفي وزيـادة نسبة التحصيل الاراسـي؛ ودراسـة لين، كو، لين، لين، Lin, Kuo, Lin, Lin, Chang, تثـانغ، وليو and Liu (2012) التعلم النقال لها فاعلية على خفض الحمل المعرفي Kim, and لدى المتعلمين؛ دراسـة كيم، جيلمـان Gilman (2008) الرسومات فاعليتها أفضل في تنميـة تعلم مفرادات 
البعـدي يرجـع إلــ أثـر اخـتلاف الأسـلوب المعرفي (الاسـتقلال/الإعتماد) فـي بيــة الـتعلم النقـال لصـالح المجموعة التجريبية ذات الأسـلوب المعرفي المعتمد على المجـال"، ممـا يشير إلى تقدمها في التحصيل الاراســي عـن المجموعـة ذات الأســلوب المعرفـي المستقل عن المجال. وهذا يعني أن الطلاب المعتمدين كانوا أكثر تقدمًا في التحصيل الدراسي من خلال بيئة

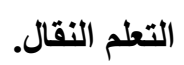

ويمكسن تفسير هـذه النتيجـة إلـى أن الطـلاب

المعتمـدين كـانوا أكثر إهتمامَّا بمتابعـة التلميحسات

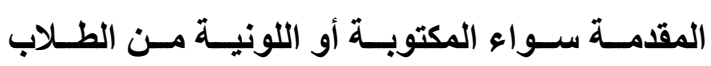
المستقلين مـن خـلال بيــة التعلم النقـال، ولكن التعلم النقـال يعطي الحريـة للمتعلمين بـالتجول الحر داخل البيئة التعليمية في أي وقت وأي مكان، فعملت هذه الحريـة على عـدم تركيـز الطـلاب المسـتقلين نحسو محتوى تعلمهم بالطريقة الجيدة حيث لأحظ الباحثان أن الطلاب المسـتقلين قلمـا اعتمـدوا علـى التلميحـات المقدمـة بخـلاف الطـلاب المعتمـدين، ولـلتلك سـاعدات التلميحات الطلاب المعتمدين في التعلم النقال كمثيرات فعالــة لجــب انتبـاههم نـــو المحتوى المـراد تعلمـه. وأيضًا ترجع هذه النتيجة إلى طبيعة المحتوى المراد تعلمـه وهــو إنتــاج الإنفوجر افيـك الثابــت بيرنسامج الفوتوشوب حيث يحتاج المتعلم بصفه مستمرة إلى بعض التوجيهات لتحسين منتجهـ من ناحيـة الجاتب المعرفي، فالطلاب المعتمدين يحتاجوا بإستمرار مثل هـذه التوجيهـات بخـلاف الطـلاب المسـتقلين اللـذين
يمكن للباحثنان أيضًا أن يفسروا هذه النتيجة

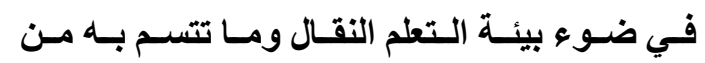
خصائص من حيث إتاحة المحتوى للطلاب في أي وقت ومكان، وإتاحة التفاعل بين المعلم والمتطمين وبعضهم البعض، أيضًا المرونـة في تقديم الأنثطة والتكليفـات وتقــيم التلميحـات إلـى المتعلمـين كـل حسب قدراته واستعدادته النفسية، وإتاحة التثـارك بطريقــة إيجابيـة فيمـــــين المتعلمـين وبعضــهم البعض، وهذا ما تؤكد علية مبادى ع النظرية البنائية من حيث أن التعلم النقـال يخلق بيــة تعلم جديدة، ومواقف تعليمية جديدة، تقوم على أسـاس التفاعل والتعلم التثاركي؛ والتكيف، فالتعلم النقال يقوم على جلى أساس تكيفه مـع حاجـات المتعلمين؛ ويمكن تفسير النتيجة أيضًا وفقَا لمبادى ع نظرية النشاط فإن التعلم

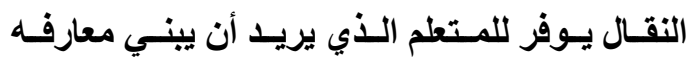
بنفسـه مـن خـلال البحـث والاكتثـــــ والتلخـيص والإطـلاع الفرصـة للنلك، وفي نفس الوقت تعطي للمتعلم الآخر الذي يحب التفاعل الإجتمـاعي مـع لـع الآخرين ويعتمد على الجو الإجتمساعي أيضًا نفس الفرصة بيئة التعلم النقال على التحصيل الدراسي: وفقـا لنتـائج الفـرض الثـاني والـذي تـم رفضـهـ وقبـول الفـرض البـديل وهـو "يوجـ فـرق ذو دلالــة إحصـائية بين متوسطي درجـات طلاب المجمو عتين التجريبيتين في اختبـار التحصيل الدراسـي للتطبيتق 
الجمعية المصرية لتكنولوجيا التعليم

تميزهم عن المعتمدين من حيث الاستقالية والاعتمـاد على الـنفس وعـد الإجتماعيـة، ولكن اختلفت هـذه النتيجة مـع عديد من نتائج الدراسـات كدراسـة أحمد فهيم (ـ ا ـ ץ) التي أثثتت أن الطلاب المستقلين أكثر تقدمًا في تحصيلهم الدراسي عن الطلاب المعتمدين؛

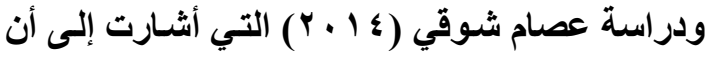
الأسلوب المعرفي للمتطلم لـه تأثير على نواتج التعلم والحمـل المعرفي، حيث أن الطـلاب المستقلين أكثر تفوقا من المعتمدين في اختبار نـواتج التعلم ومقياس الحمل المعرفي؛ ودراسـة ربيع رمود (r ا ـ r) التي أوصت بأن للأسلوب المعرفي ليس لـه أثرًا على كل من المستقلين والمعتمدين فكان تأثيره متسـاوي في تنميسة التحصـيل الدراســي؛ ودراسـة هبــه عثمــان

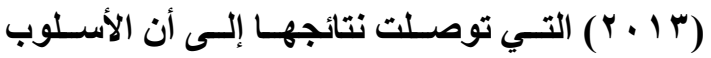
المعرفي الإعتمـاد في مقابل الاستقلال سـاعدا بثكل متساوي في تنمية التحصيل المعرفي؛ ودراسـة أميرة المعتصـم ( • ( + ) والتـي توصلت إلى عدم وجـود تأثير أساسي للأسلوب المعرفي الاستقلال في مقابل الاعتمـاد عن المجـال الإدراكي على تنميـة التحصيل، زمسن الـتطلم، والقابليـة للاسـتخدام؛ ودراســة زينـب

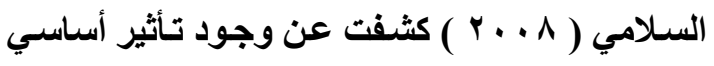
لأســلوب الـتـعلم علــى التحصـيل لصـــالح الطــلاب المستقلين.

- - تأثير التفاعل بين نمط التلميحات (المكتوبة/اللونية) والأسلوب المعرفي
يعتمـدون علـى أنفسـهم وهــا لا يصـلـح مــع إنتـــاج الإنفوجرافيك فدائما يحتاج المنتج إلى عمليات تقويم مستمرة وتقديم توجيهات لتحسينه. وترجع نتيجـة هذا الفرض أيضًا إلى خصـائص الطـلاب المعتمـدين علـى المجــال كتــعيمهم بييــات التعلم الاجتماعية، ويفضلون توجيه إستراتيجيات قبل توجيه التعلم، تقديم تلميحـات تخطيطية أو شفهية أو صوتية؛ يدعم التلميحـات البـارزة الخارجية من أمثلـة المنظمات المتقدمة؛ لهم اتجاهـات صريحة ويفضلون الإرشـاد ويتظوقون دائمَا للمسـاعدة؛ يفضلون تغذيـة راجعة واسعة وخاصة المثقفون منهم؛ ملائمة المنظم المتقدم مـع تلـك الصـفة (مـنظم لفظي أو شـفهي أو مصور)؛ وضـع نقـاط أساسية للمحتوى الدراسـي أو منظمسات تخطيطيـة؛ تقديم نمــاذج وأمثلـة تمهيديسة؛ الاحتياج إلى دعم تعليمي للمتعلمين على شكل (أمثلة،

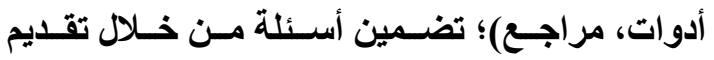
التعليم؛ الاهتمـام بالأسـلوب الاسـتنتاجي فـي تنظيم المحتوى وكذلك تقليم تتابعات إجرائية تعليمية، وهذا مـا يجدونــه الطـلاب بيئـة الـتعلم النقــال مـع تقـــيم

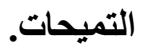
واتفقت هذه النتيجـة مـع نتيجـة إيمـان صـلاح

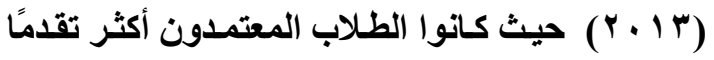
في التحصيل الار اسـي مـن الطلاب المستقلين نظرا إعتمـادهم على التلميحـات المقدمـه لهم بغض النظر عـن شـكلها بعكس الطـلاب المسـتقلين اللــين يقـل اعتمادهم على تلكك التلميحات فلهم خصائصهم التي

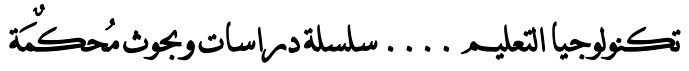


بشـكل متســاوي فـي تنميـة التحصـيل المعرفي ؛

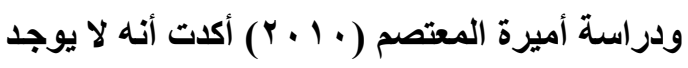
تفاعل والتي توصلت إلى عدم وجود تأثير أساسي

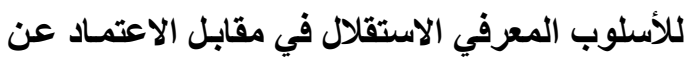
المجال الإدر اكي على تنمية التحصيل؛ ودراسة يـاتج Yang (2016)

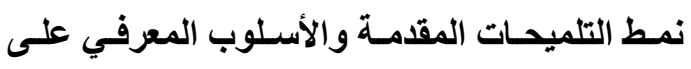
تنمية التحصيل الدراسي، ولكن اختلفت نتيجة هذاب

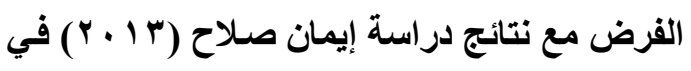

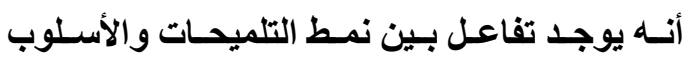

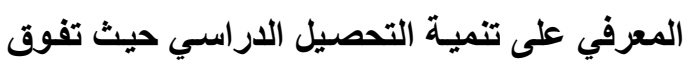
الطلاب المعتمدون على المجال مـع تقديم التلميحـات اللونية لهم على الطلاب المستقلون؛ ودراسـة زينب

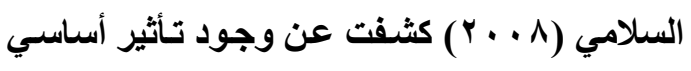

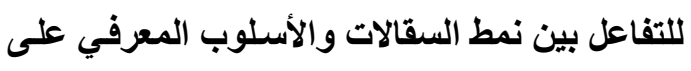

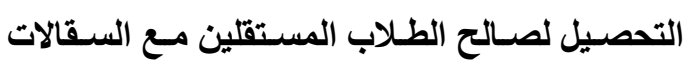
المرنة، ولكن كما تم ذكره هذا الاختلاف يرجع إلى الـى تعدد البيئـات المستخدمة في كل دراسـة، وكل بيئة

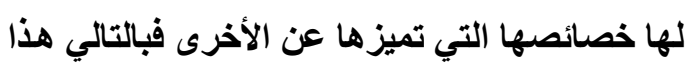

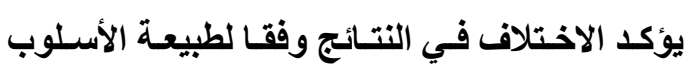

• تفسير النتائج المرتبطة بالأداء المهاري

- تأثير نمط التلميحات (المكتوبة/اللونية) بييئة التعلم النقال على الأداء المهاري:

وفقـا لنتائج الفرض الرابـع والذي تـم رفضـه وقبول الفرض البديل وهو "يوجد فرق ذو دلالـة إحصائية بين متوسطي درجات طلاب المجموعتين
(المستقل/المعتمد) ببيئة التعلم النقال على

$$
\text { التحصيل الاراسي: }
$$

وفقـا لنتـائج الفـرض الثالث والذي تـم رفضـه وقبول الفرض الصفري وهو "لا توجد فروق ذات

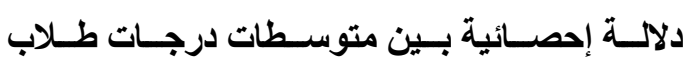

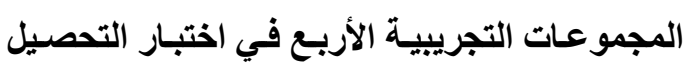

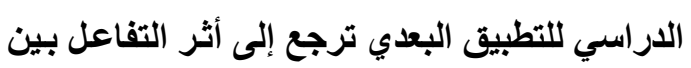

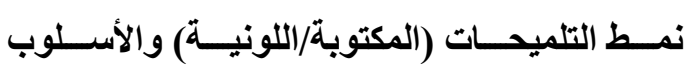

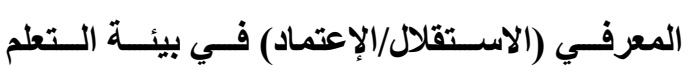

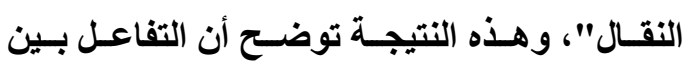
المتغير المستقل والمتغير التصنيفي لـم يؤدى إلى الـى

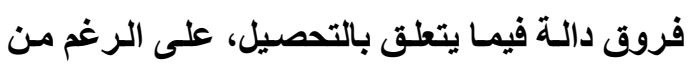

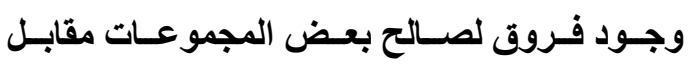
مجموعات أخرى فيما يتعلق بالتحصيل إلا أن هذا لـ لم

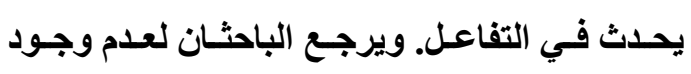

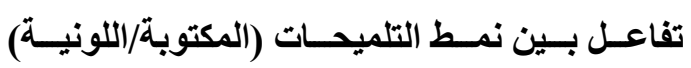

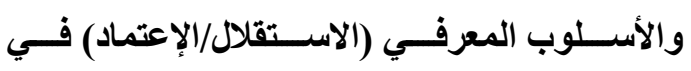

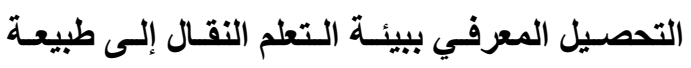

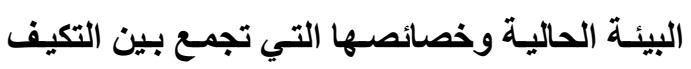

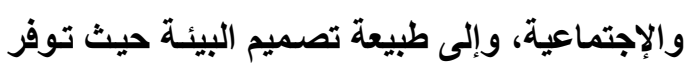

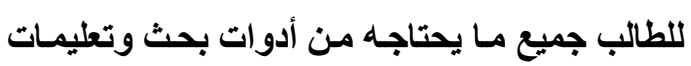

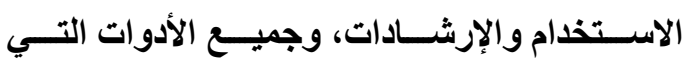
يحتاجهـا والمحتـوى والأنشـطة المختلفـة، وكيفيـة ولادية وضع الأثطة.

اتفقت نتيجة هذا الفرض مع نتائج دراسة هبه

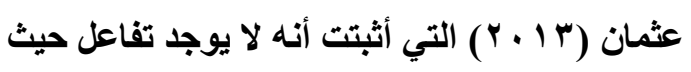
توصلت نتائجها إلى أن الأسلوب المعرفي الإعتمـاد

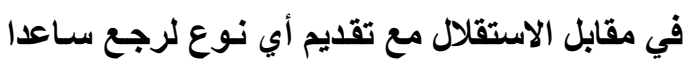


الجمعية المصرية لتكنولوجيا التعليم

المحتوى المـراد تعلمـه، وأكدت نتيجـة هذا الفرض

التجريبيتين في بطاقة تقييم الأداء للتطبيق البعدي وفَّا لمـا تتسـم بهـا التلميحـات بصـفة عامـة مـن

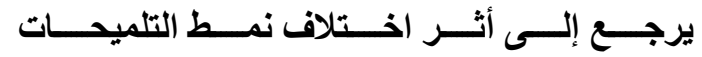
خصائص حيث ساعدت التلميحات وخاصة المكتوبـة (المكتوبة/اللونيـة) فـي بيئسة الـتعلم النقــال لصـالح الطلاب على أنها عملت على جذب الانتباه حيث أدت

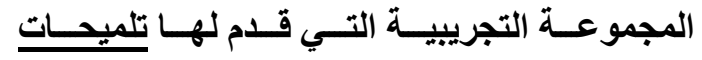
إلى توجيه انتباه الطلاب نحو المعلومـات التي يجب مكتوبة"، مما يشير إلى تقدمها في الأداء المهاري أن تحظى بالاهتمـام وتبعـده عن المعلومسات الأقل عن المجموعة التي قدم لها تلميحـات لونيـة. وهذا

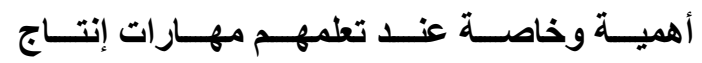
الإنفوجر افيك، بالتـالي سـاعدت على زيـادة قدرتهم يعنـي أن التلميحـات المكتوبـة أدت إلـى تنميـة الأداء المهاري للطلاب وذلك من خلال بيئة التعلم النقال. على الفهم والاستيعاب، وجعلت الطلاب قادرين على

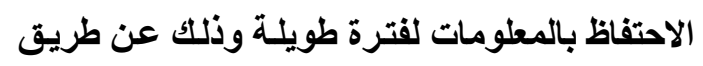
ربـط المعلومـات الجديـدة بالمعلومــات السـابقة ذات الصــله بموضــوع الـتعلم، بالإضــافة إلـى عمليـة اسـترجاع المعلومـات تـرتبط أيضًّــا بجــب الانتبـاه والفهم للمحتوى المطلوب تعلمـه حيث ينتبه ويفهم التلميح ثم يسترجع المتعلم المعلومات للاستخدام في المستقبل، أيضًا سـاعدت التلميحـات المكتوبـة على سـرعة توصيل الرسـالة عنــ مشــاهلتها مـا دامـت مناسـبة لمسـتوى فهـم مسن يتلقونهـا وهـم طـلاب

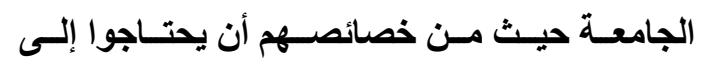
توضيح مكتوب وليس مساحات لونية أمسامهم لنقاط

$$
\text { اتعلم المطلوبة. }
$$

كما اتفقت نتائج الفرض الحالي مـع مـا أكدت عليـهـ النظريـة البنائيسة فـي أن بيـــة الـتعلم النقــال ساعدت على تنمية الأداء المهاري للاي الطلاب في إنتـاج الإنفوجرافيك، حيـث أن إتبـاع نهـج النظريـة البنائية وذلك من خلال التمثيل الفردي للمعرفة من

حملت نتائج هذا الفرض نفس توجهات نتائج الفرض الأول حيث تفوقت المجموعة التجريبية التي قدم لهـا تلميحـات مكتوبـة بثـكل واضـح في تنميـة الأداء المهاري أفضل من المجموعة التي قدم لها تلميحات لونيـة، حيث يرجع الباحثان هذه النتيجة إلسى نفس الأسباب التي فسرت تفوق المجموعـة التجريبية التي قدم لها تلميحات مكتوبـة في تنميـة التحصيل الاراسي، نظرًا لإتفاق التوجهات التي أدت لهذه النتيجة من وجهة نظر الباحثان، وأيضًا إرتباط التفسير بخصسائص التلميحـات وأهميـة تقديمها في بيئات التعلم النقال والنظريات المرتبطة بها، وأيضًا يضـاف إلى ذلك إلى أن طبيعة عملية التدريب في تعلـم المهـارات الخاصـة بإنتــاج الإنفوجر افيـك مسن خلال بيئات التعلم النقال تحتاج إلى تقديم التلميحات بصفة مستمرة للطلاب لتوجيههم نحو عملية التعلم وتجعلهم غير مشتتين نظرًا لما تتسم بـه بيــة التعلم النقال من أن للمتعلم كامـل الحريـة في عمليـة تعلمـه فلذلك عملت التلميحات على توجيـه وتحفيزة نحو

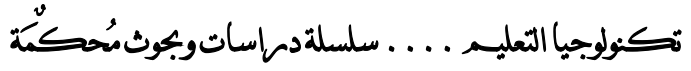


أداء المهارات، بخلاف ذلك اتفقت نتيجة هذا الفرض مع نتائج دراسة إيمـان صلاح الدين (T I ب Y) التي توصلت نتائجها أن تقايم التلميحات لها أهمية كبيزة في رفع أداء الطلاب في المهارات العملية؛؛ ودراسـة Boucheix, بوشسيكس، لـو بـوتري، وجـروف Lowe Putri, and Groff, (2013) على أهميـة التلميحـات المكتوبـة بجانـب اسـتخدام تلميحات أخرى لتوجيه الطلاب نحو عملية التعلم؛ Kim, and Gilman دراسـة كيم، جيلمسان (2008) أن التلميحــات المكتوبــة مـع الرســومات فاعليتهــا أفضـل مـن التلميحـات المسـموعة مــع الرسومات على تنميـة مهارات تعلم مفرادات اللغـة الإنجليزية من خلال بيئة تعلم عبر الويب؛ ودراسـة

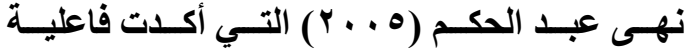
التلميحات اللونية للنصوص فقط حيث أظهرت أعلى كفاءة في تتمية المهارات عن التلميحات السمعية. - تأثير الأسلوب المعرفي (مستقل/معتمد) بييئة التعلم النقال على الأداء المهاري:

وفقا لنتائج الفرض الخـامس والذي تم رفضـه وقبول الفرض البديل وهو " يوجد فرق ذو دلالـة إحصائية بين متوسطي درجات طلاب المجموعتين التجريبيتين في بطاقة تقييم الأداء للتطبيق البعدي يرجــع إلــــ أثــــر اخــتلاف الأســلوب المعرفـــي (الاستقلال/الإعتماد) في بيئـة التعلم النقـال لصـالح المجموعة التجريبية ذات الأسلوب المعرفى المعتمد علـى المجـال، ممــ يشـير إلـى تقــدمها فـي الأداء
خـلال الاستكثــف النشــط، والمراقبـة، والتجهيـز، والتفسير، الذي يتيح للطلاب الانخر اط بعـق مـع المحتوى، وهذا من شـأنه أن يوفر فرصـة للطلاب ليس فقط في أن يكونـوا نشطين في عمليـة التعلم ولكن يسـاعد أيضًا في إظهار معرفتهم وقدراتهم

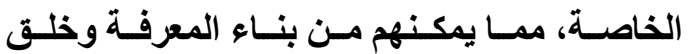
معسارف جديدة مبنيـة على التعلم السـابق بالتثـارك والتعـاون مـع أقرانـه في جـو إجتمــاعي، وتحقيـق المرونــة والتتعلم الـذاتي، كمـا يجعل الطـلاب أكثر

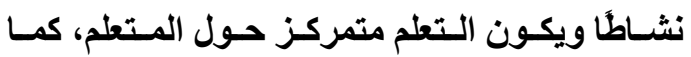
تســـل تقـــيم التلميحـات لهـم اتركيـز علـى تعـم المحتوى المراد تعلمه دون تثتيت. ولكن اختلفت نتيجـة هذا الفرض مـع نتـائج Lin, دراسـة لين، كو، لين، للين، تثــانغ، وليو Kuo, Lin, Lin, Chang, and Liu (2012) بــأن تقـــيم التلميحــات بــأي شـكل عنـــ استخدامها في التـطم النقـال لهـا فاعليـة ولا يوجد

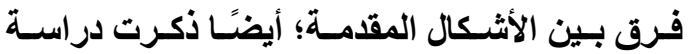

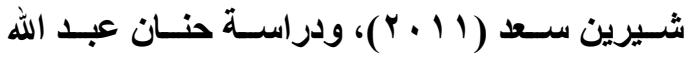

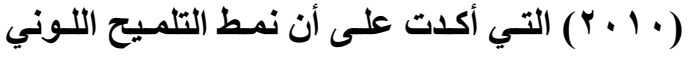
أفضـل مـن التلميـــات الأخـرى؛ ودراســة كـل مـن Mautone, and Mayer موتـون، مساير (2001)؛ ودراسـة زهـاريف، كريستين، مسكينزي Zahariev, Christine, and MacKenzie (2003) أن فاعلية التلميحات المسموعة أفضل من التلميحات البصرية في تحسين قدرة الطلاب على 
الجمعية المصرية لتكنولوجيا التعليم

(Zurit, \& Nussbaum, المتعلمين للتعلم 2007, p.p. 209-222) وهذا يؤكد على تفوق الطـلاب المعتمــدون علـى المسـتقلون فــي الأداء المهاري حيث تتفق خصائصهم مـع مبادى ن نظريـة النشاط، وهذا من خلال بيئة التعلم النقال.

- تأثير التفاعل بين نمط التلميحات (المكتوبة/اللونية) المعرفي (المستقل/المعتمد) ببيئة التعلم النقال على الأداء

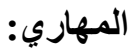

وفقا لنتائج الفرض السـادس والذي تم قبولـهـ وهـو "توجــ فـروق ذات دلالــة إحصــائية بـين متوسـطات درجـات طـلاب المجموعـات التجريبيـة الأربع في بطاقة تقييم الأداء للتطبيق البعدي ترجع

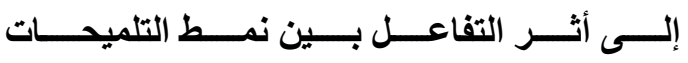

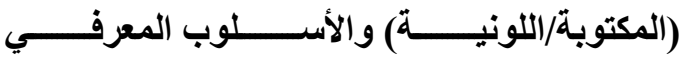
(الاستقلال/الإعتماد) في بيئـة التعلم النقـال لصـالح المجموعـة التجريبيـة التي التـى قدم لهـا تلميحـات مكتوبة للطلاب المعتمدون ويدل متوسطها المرتفع

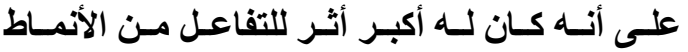
الأخرى. وهذا يعنـي أن تقديم التلميحـات المكتوبـة للطـلاب المعتمــدون ســاعدا علـى تنميــة أدائهــم المهــاري بشــل أكبـر مـن التلميحـات اللونيـة مـعـ الأسلوب المعرفي سواء المعتمد أو المستقل وذلك من خلال بيئة التعلم النقال.
المهــاري عـن المجموعـة ذات الأســلوب المعرفـي المسـتقلّ عـن المجــال. وهـــا يعـــي أن الطــلاب المعتمدين كانوا أكثر تقدمًا في الأداء المهاري من خلال بيئة التطلم النقال. حملت نتائج هذا الفرض نفس توجهات نتائج الفرض الثاني حيث تفوق الطلاب المعتمدون بشكل واضح في تنمية الأداء المهاري لايهم وكانوا أفضل من الطلاب المستقلون، حيث يرجع الباحثنان هذه النتيجة إلى نفس الأسباب التي فسرت تفوقهم أيضًا في التحصيل الار اسـي وذلك من خـلال بيئسة التعلم النقال وتقديم التلميحـات وخصائصـهم التي جعلتهم

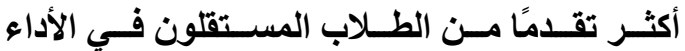
المهاري وتفاعلهم مع بعضهم البعض للتوصل ألى أفضــل منــتـج للإنفوجرافيـــ، حيــث أن إنتــــاج الإنفوجر افيك وخاصـة بيرنـامج الفوتوشـوب يحتـاج مـن الطـلاب بصـفة مسـتمرة آراء كـل مـن المعلـــ والأقران حيث يصل إلى أفضل شكل لتقديمه. ويشير الباحثنان أيضًا بأن نتيجة هذا الفرض توكدها نظريـة النشـاط حيث أنها تركز على التعلم التعـاوني والتثـاركي، حيث يحدث البنـاء المعرفي

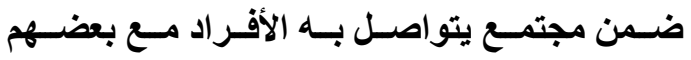
البعض، وبيئة أو نظسام يسـهم في مســاعدة الأفراد علـى طـرح تسـاؤلاتهم وتفسـير آرائهــم وعكس

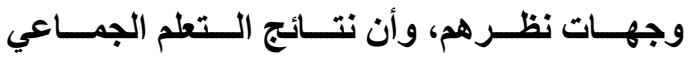

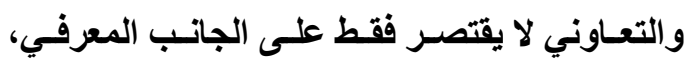

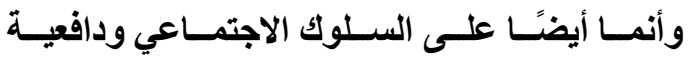

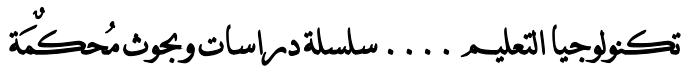


المسندة إليهم، ويفضلون التعلم في جو اجتمـاعي، والتعلم في أي وقت وأي مكان وهذا مـا أتاحتـه بيئة التعلم النقال في البحث الحالي لهم، وتلقي تلميحات مكتوبـة سـاعدتهم علـى تبـادل الأفكـار وتـوجيههم التوجيـه السليم نحو إنجـاز الأنثطة الخاصـة بهـ، وهذا جطلهم يكتسبون مهارات تصميم الإنفوجرافيك الثابت بدرجة أفضل من الطلاب المستقلون اللذين كانوا يعتمدون على أنفسهم دون الأهتمام بشكل جيد إلى التلميحات المقدمة سواء المكتوبة أو اللونية. ويرجع الباحثنان إلى وجود أثرًا للتفاعل بين نمط تقديم التلميحات (المكتوبة/اللونيـة) والأسلوب المعرفــي (المعتمد/المســتقل) لصــــالح الطــلاب المعتمدون المقدم لهم تلميحات مكتوبـة وذلتك لتنوع خصائص البيئة، وقيامها على مبادئ التعلم النشط والتعلم البنـائي والبنـائي الإجتمـاعي ممـا يولـا للاى

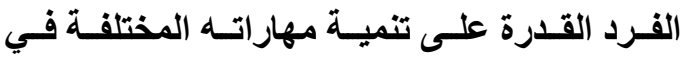

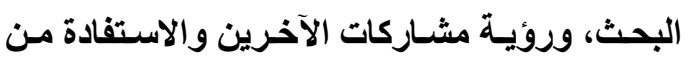

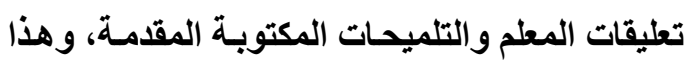
مـا اتفق مـع الطـلاب المعتمـدون بخـلاف الطلالـب المستقلون.

واختلفت نتيجة هذا الفرض مـع نتائج دراسـة

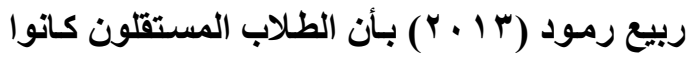
أفضل من المعتمدين في الأداء المهاري مـع التظذيـة

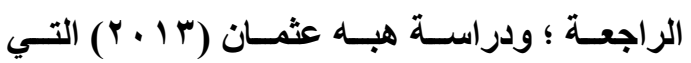
توصلت نتائجها إلى أن الأسلوب المعرفي الإعتمـاد في مقابل الاستقلال ساعدا بثكل متساوي في تنميـة الأداء المهاري مع التغذيـة الراجعة؛ ودراسـة سـعاد
تعارضت نتائج هذا الفرض مـع نتائج الفرض

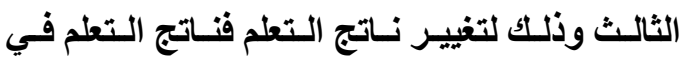
الفرض الثالث هو التحصيلي الدراسي ونـاتج التعلم في هذا الفرض هو الأداء المهاري، فكل نـاتج لـه طرقه الخاصة في تعلمه، فالتحصيل الاراسي يعتمد إلسى توجيهـات بسـيطة نظـرًا لوجـود مصـدر دائـم للحصول على المعرفة وهو المحتوى المتـاح عبر بيئـة التعلم النقـال، بخـلاف الأداء المهـاري للطـلاب فهو متجدد بإستمرار وغير ثُابت فبالتالي يحتاج إلى توجيهات بصفة مستمرة وهي متمثلة في التلميحات

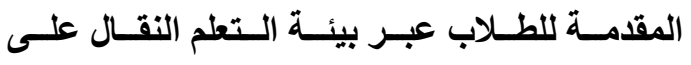
المنتجات التي قاموا بها من خلال تنفيذهم للأنشطة الخاصـة بالإنفوجر افيك، ولكن الطـلاب المعتمــون كسانوا أكثر إهتمـامَّا مـن الطـلاب المسـتقلون بتلــك التلميحات لذلك تفوقوا عليهم في أدائهم المهاري، وأيضًا بيئة التعلم النقال ساعدت الطلاب على تبادل الخبرات فيمـا بيـنهم مـن خـلال تواصلهم المستـمر ومشاركتهم أعمالهم فيما بينهم وتوجيه المعلم لهم وهـا مـا ينطبق على الطـلاب المعتمـدون، عكس الطـلاب المسـتقلون كـانوا يعتمـدون على أنفسـهـم وغيـر مهتمـين بالتلميحـات المقدمسة لـذلك تفوقـوا الطلاب المعتمدون عليهم في أدائهم المهاري في إنتاج الإنفوجر افيك. ويمكن تفسير هذه النتيجة أيضًا بـأن الطلاب المعتمدون اتفقت خصائصـهم مـع تقديم التلميحـات المكتوبة لهم عبر بيئة التعلم النقال، فهم يميلون إلى الإستفسار والاعتماد على الغير في إنجاز الأنشطة 
المجموعـة التجريبيـة التــي قــــم لهــا تلميـــات مكتوبــة."، وقبـول الفـرض الثـامن على أنـه " لا يوجد فرق ذو دلالة إحصائية بين متوسطي درجات طلاب المجموعتين التجريبيتين في اختبار التفكير الابتكـاري للتطبيتق البعدي يرجـع إلى أثر اختلاف

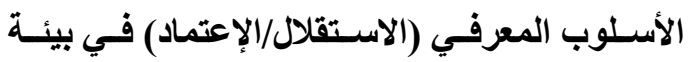
الـتعلم النقــال"، ورفضض الفـرض التاسـع وقبـول الفـرض الصـفري على أنـه "لا توجــ فـروق ذات

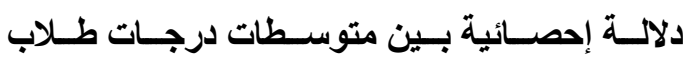
المجموعـات التجريبيـة الأربـع في اختبـار التفكير الابتكاري البعدي ترجع إلى أثر التفاعل بين نمط لهـ

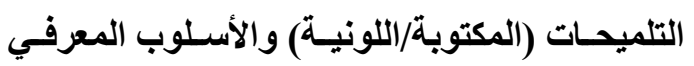
(الاستقلال/الإعتماد) في بيئة التعلم النقال." ترجع نتيجة الفرض السادس وهو وجود فرق لصالح المجموعة التي درست من خلال بيئـة التعلم

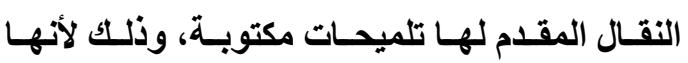

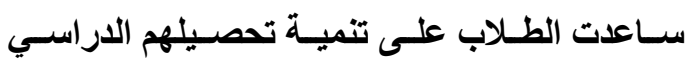

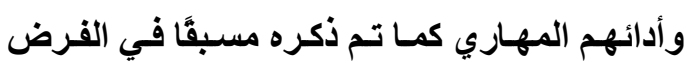

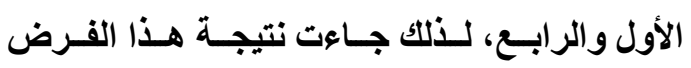

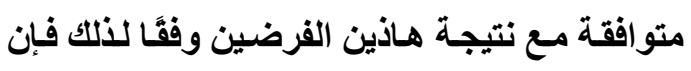
محصلة إرتفاع نواتج التعلم السابقة أدت بالتالي إلى ملى إرتفاع التفكير الابتكاري لاى الطلاب، ونظرًا لتميز التلميحات وخاصة المكتوبة بأنه تم تقديمها بطريقة متنوعة ومبدعة فساعدت المتعلمين على ربط التعلم الجديد بالتعلم السابق والاستفادة منه في المستقبل،

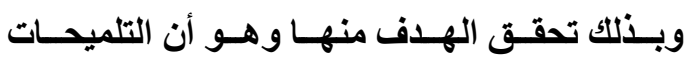
سـاعدت المتعلمـين على فهـم المعلومسات الجديـــة
شاهين (Y. . . V كثفت عن عدم وجود أثر للتفاعل بين التخصـص الأكساديمي والأسـلوب المعرفي في ولي تصـيم وإنتـاج ملـف الإتجـاز الإكترونسي؛ ودراسـة

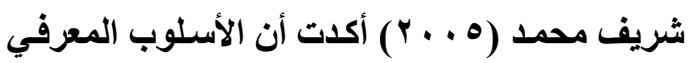
الاستقلال في مقابل الاعتماد عن المجال الإدراكي له أثر دال إحصائيًا على تحصيل الطلاب و على معدل

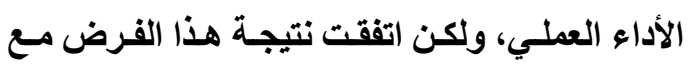

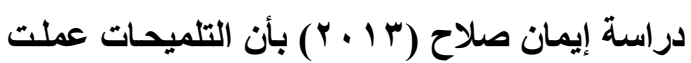
على تنمية الأداء المهاري بشكل أكبر للدى الطلاب المعتمدون، عكس الطلاب المستقلون فمستوالهم لـ يتغير وهذا يثبت أن يوجد تفاعل بين التلميحـات والأسـلوب المعرفي لصـالح المعتمـدون؛ ودراســة

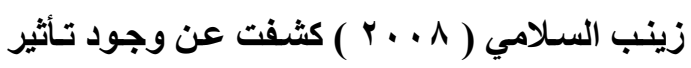
أساســي للأسـلوب المعرفـي على مهــارات الـتعلم الأتي لصالح الطلاب المعتمدين. • تفسير النتائج المرتبطة بالتفكير الابتكاري والأسلوب المعرفي (مستقل/معتمد) والتفاعل بينهم ببيئة التعلم النقال على ولى

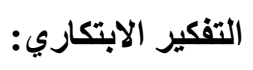

وفقــا لنتــائج الفـرض الســابع، الثـامن، و التاســـ والــي تـم رفض الفـرض الســابع وقبـول الفرض البديل بحيث يوجد فرق ذو دلالة إحصائية بــين متوســطي درجــات طــلاب المجمــوعتين التجريبيتين في اختبـار التفكير الابتكاري للتطبيق درجي

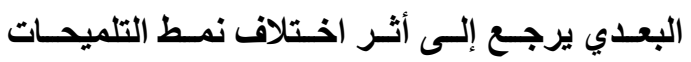
(المكتوية/اللونيـة) في بيئـة الـتعلم النقـال لصـالح

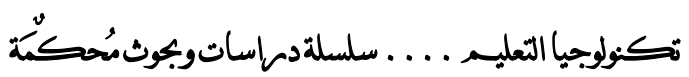




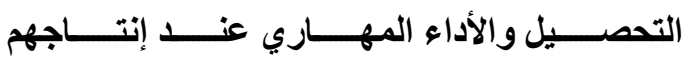
الإنفوجرافيك على الطلاب المستقلون ويإعتبار أن التفكير الابتكـاري تنميته محصلة لهم إلا أن نتيجـة

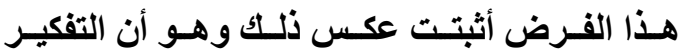

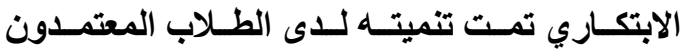
والمستقلون بثكل متساوى، وكمـا ذكر الباحثّان أن

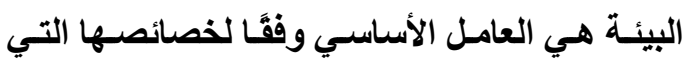

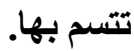

أيضًا تعارضت نتائج الفرض التاسع مع نتيجـة كل من الفرض الثالث والسـادس بأنها لا يوجد أثرًا للتفاعـل بـين نمــط التلميحـات المكتوبــة واللونيـة والأسـلوب المعرفي المستق والمعتمــ على تنميـة التفكير الابتكاري، وقد أرجع الباحثان هذه النتيجـة إلى أن التفكير الابتكاري من المهارات العليا للتفكير التي تعتمد على التأمل والإطلاع وهذا ما أتاحته بيئة التعلم النقـال لمـا تتسـم بهـا مـن خصـائص كمــا تـم ذكرهــا مســبقَّا، علــى الـرغم مــن أن التلميحــات المكتوبة المقدمة كانت أفضل من التلميحات اللونية في تنمية التفكير الابتكاري دون تصنيف الطلاب إلى معتمــدون ومسـتقلون، كمــا يـرتبط الـتـلم النقــال والأســلوب المعرفــي بأنمــاط التفكيـر كــالتفكير الابتكـاري، ممـا يسـاعد على إمكانيـة التببؤ بسلوك

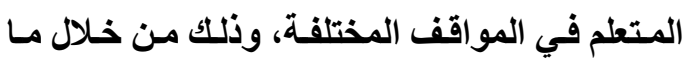
يتيحسه الأسـلوب المعرفي مـن الكثـف عن الفروق الفردية بين المتعلمين في كل من الجوانب النفسية و الاجتماعيـة والتـي تتميـز بالثبـات النسبي، ولمـا تتسـم بـه بيــة التعلم النقـال مـن أنها بيئسة متكيفـة
وانتقــال أثر التعلم ممـــــــاعدا على زيـادة التفكير الابتكـاري للدى الطلاب. ونظرًا لمسا تتسـم بـه بيــة التعلم النقال من أنها بيئة تعليمية متنقلة؛ فالتعلم يتم في أي وقت وأي مكان بمعنى إعطاء الحرية للمتعلم دون قيـود وقــــــؤدي هـذه الحريـة إلـى تثــيت

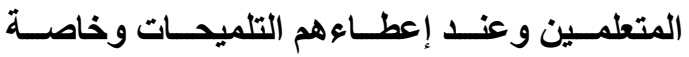
المكتوبـة ســاعدت على تنميسة تحصيلهم المعرفي وأدائهـــم المهـاري ممـــا أدات إلـى تنميـة تفكيـرهم الابتكاري، وذلك لأن التلميحات المكتوبـة أكثر فهمـا من التلميحـات اللونية للاى المتعلمين فعلت على تركيز هم في المحتوى المقدم لهـم وأيضًا متابعـة أعمال أقرانهم مما جعلتهم أكثر توليدا لأفكار جديد

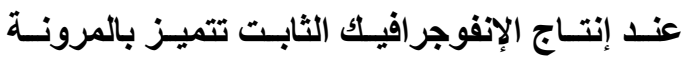
و الطلاقة والأصالة.

تعارضـت نتيجـة الفـرض الثـامن مـع كل مـن نتيجـة الفرض الثاني والخـامس بأنـه لا يوجد فرق بـين الطـلاب المعتمـدون والمسـتقلون فـي اختبـار التفكير الابتكاري عند دراستهم من خلال بيئة التعلم النقال سواء بتقديم التلميحات المكتوبـة أو اللونيـة،

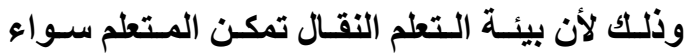
المعتمـــ أو المسـتقل مسن الوصـول إلـى البيئة في الوقت والمكان الذي يناسبه حسب رغبته؛ فالتعلم النقـال يخلـق بيــة تعلـم جليـدة، ومواقف تعليميـة جليدة، تقوم على أساس التفاعل والتعلم التشـاركي؛ التكيف، فـالتطلم النقـال هـو بطبيعتهـه تعلـم تكيفـي، بمعنى أنـاه يتكيف مـع حاجـات المتعلمين المختلفة، وعلى الـرغم مـن تقـــم الطـلاب المعتمـدون فـي 
الجمعية المصرية لتكنولوجيا التعليم

r. الأهتمــام بإكسـاب طـلاب تكنولوجيـا التعلـيم

مهارات إنتاج الإنفوجرافيك التعليمي لمـا لـه

مـن أهميـة كبيـرة فـي تبسـيط المحتـوى لهـي

التعليمي لجميع المستويات.

r. اســتخدام التلميحــات المكتوبــة مـــع الطــلاب

المعتمـين و المسـتقلين بشـكل متسـاوي لتنميـة

التفكير الابتكاري لاى المتطمين في بيئات التعلم

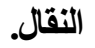

؛. ـ لفت نظر الباحثيين إلى وجود أثرًا للتفاعل

بـين متغيـرات البحــث لصــالح التلميحـات

المكتوبـة مـع الطـلاب المعتمـدون في بيـــة

الـتـطم النقــال لتنميـة كـل مسن التحصـيل

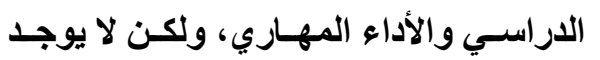

تفاعل عند تنمية التفكير الابتكاري.

\section{هقتز حات البمث:}

ا. ـ دراســة العلاقــة بـين أنمــاط أخــى مـن

التلميحـات والأســلوب المعرفـي فـي بيئـة

$$
\text { البحث الحالي. }
$$

r. دراسـة العلاقـة بـين كميـة التلميحـات وتوقيــ

تقليمها في تنمية بعض نواتج التعلم .

r. دراسة تأثير مصدر التلميحات مع بيئة التعلم

$$
\text { النقال في تنمية بعض نواتج التعلم. }
$$

ع. بــاء نظـام للتلميحـات التكيفيـة وقيـاس أثره

$$
\text { على نواتج التعلم. }
$$

تصــلح لجميـع المتعلمسين إذا أحسـن تصـميمها كمـا بالبحث الحالي.

وفي إطار نظرية التعلم الثبكي التي تستهدف وضع المتعلم في علاقات تثابكية مع آخرين كما في بيئة التعلم النقال التنفيذ أهداف عملية التعلم، حيث ساهم التعلم النقال في خلق سـاحة إلكترونية تســح

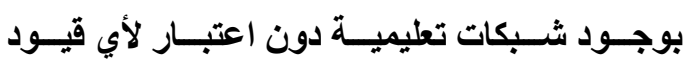
مكانيـة، فيؤدي ذلك إلى خلق بيئة محفزة للابتكار والإبداع، وخاصـة في ظل أن هذه السـاحة الثبكية الكبيرة يتم مـن خلالهـا تقديم كافـة المحتويـات في في إطـار من التوافق مـع الخصـائص المعرفيـة للمتعلم ممـا يـوفر بيــة خصـبة نحسو الوصـول إلـى أفكـار

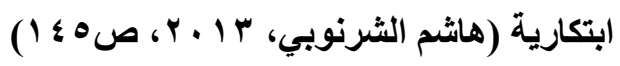
ويرجع الباحثان نتيجة البحث الحالي في أنه لا يوجد تأثير للتفاعل بين نمط التلميحات والأسلوب المعرفي إلى نفس الأسباب التي فسرت عدم وجود فـرق بـين الأسـلوب المعرفي، وأيضًا طبيعـة بيئسة التعلم بالبحث الحالي إدت إلى نفس النتيجة كمـاتم ذكر ذلتك مسبقًا.

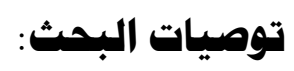
على ضوء ما أشارت بـه نتائج البحث يمكن تقديم التوصيات 1. الاستفادة من نتائج البحث الحالي في تصميم بيئات التعلم النقال مـع استخدام التلميحـات

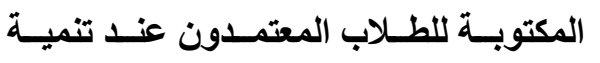

$$
\text { التحصيل المعرفي والجانب الأدائي. }
$$

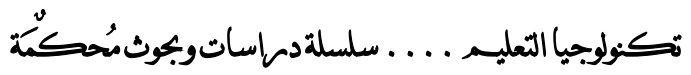


الجمعية المصرية لتكنولوجيا التعليم

The effect of the interaction between the style of cues (written/ colored) and the cognitive style in mobile learning on developing infographic production skills and innovative thinking for Educational Technology Students

\author{
Dr. Ayman Fawzy Khttab Madkour \\ Dr. Heba Othman Foud Alazab \\ Associate Professor of Educational Technology \\ lecturer of Educational Technology
}

Faculty of Specific Education- Menofia University Faculty of Specific Education- Menofia University

\title{
Abstract:
}

The aim of the current research is to reveal the study of the impact of the interaction between the cues of cues and the cognitive style in mobile learning on developing skills of fixed infographic production using Photoshop and innovative thinking among students of educational technology in the second year of the In a course to produce educational fees. it has been relayed on experimental design based on $(2 \times 2)$ was used to measure the effect of two independent variables, which are the two cues patterns (written/ colored), and the cognitive style of the mobile learning, on the dependent variables, which are cognitive achievement, and the skills of fixed infographic production using Photoshop and innovative thinking. The research tools consisted of an achievement test, a card to evaluate the performance of fixed infographic production skills using Photoshop, and an innovative thinking test. The research sample consisted of 59 male and female students and they were divided into four groups according to the cognitive method. The SPSS program was used to test the hypotheses of research, and the search results reached To: the presence of two hint cues in mobile learning in favor of written hints and that they are better than color hints on academic achievement

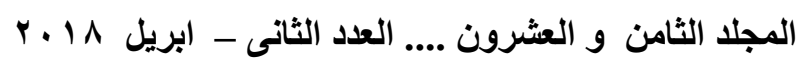


الجمعية المصرية لتكنولوجيا التعليم

development, skill performance, and innovative thinking; and that there is also an effect of cognitive style in mobile learning for the benefit of students. You provide that they are better than the independent ones when developing academic achievement, and their skillful performance, and there is no effect of the cognitive style when developing innovative thinking; and the presence of an interaction between the two cues of cognitive and cognitive style in mobile learning on the development of skill performance, and there is no effect of this interaction when developing academic achievement, and innovative thinking .

Key words: Mobile learning, Cues, Cognitive style, Infographic, Innovative thinking. 
الجمعية المصرية لتكنولوجيا التعليم

المراجع

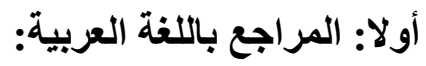

أحمد حسن خميس (r ا +r). المهام الsتقدمه في الفوتوشوب CS5. القاهرة: دار البراء.

أحمد صادق عبدالمجيد (10 1 ب). فعالية برنامج تدريبي مقترح قائم على التعلم المتنقل M-Learning في تنمية مهارات الانخراط في التعلم وتصميم وحدات رقمية لاى معلمي الرياضيات قبل الخدمة. المؤتص

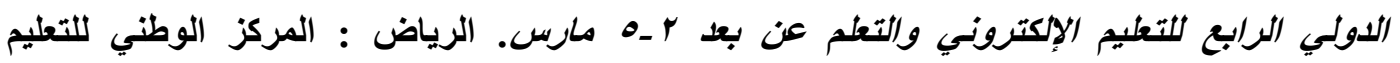
الإلكتروني.

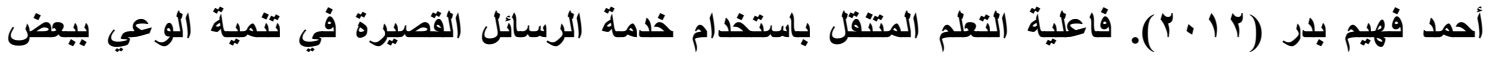

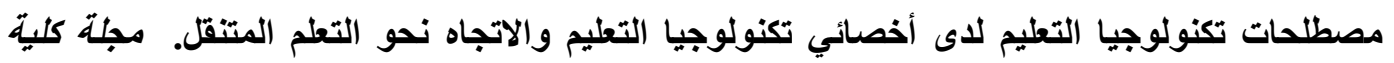

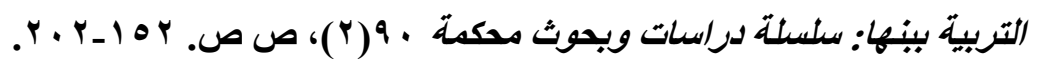

أحمد فهيم بدر (ع ا ب يناير). أثر التفاعل بين أنماط دعم التعليم والأسلوب المعرفي على كل من التحصيل

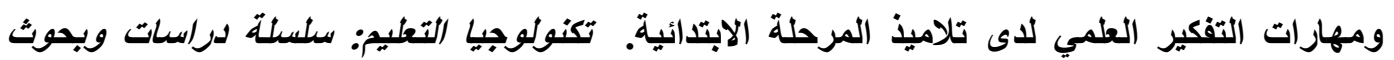

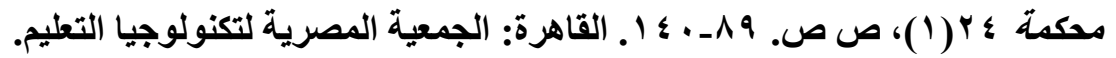
أحمد فهيم بدر (V ا ـ أكتوبر). أثر التفاعل بين نمط ممارسة الأنثطة التطليمية في بيئة التطم الإكتروني النقال وأسلوب التعلم على تنمية الدافعية للإنجاز والتحصيل المعرفي لدى تلاميذ المدرسة الإعدادية. تكنولوجيا التتربية:

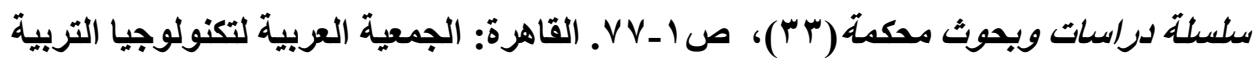
أسامة سعيد هناوي (ه . . ץ). فاعلية برنامسج مقترح قائم على الوسانط الفائقة فى تنمية مهارات طلاب شعبة تكنولوجيا التعليم وتفكيرهم الابتكارى فى التطبيقات التعليية للإنترنت. (رسالة دكتوراه، غير منشورة). كلية التربية ، جامعة الأزهر. أسامة سعيد علي هناوي، إبراهيم صبري الجيزاوي (^ ..ب أبريل). فاعلية اختلاف عدد التلميحات البصرية بيرامج الكمبيوتر التعليمية في تنمية مهارات قراءة الخرائط لاى تلاميذ الصف الرابع الابتدائي، مجلة

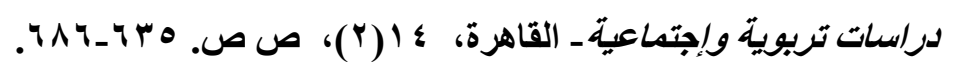

أسامة سعيد علي هنداوي، حمادة محمد مسعود إبراهيم، إبراهيم يوسف محمد محمود (9 . . Y). تكنولوجيا التعليم والدستحثات التكنولوجية. القاهرة: عالم الكتب.

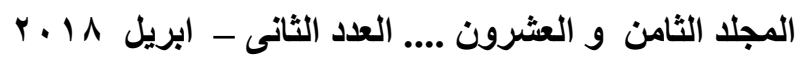


الجمعية المصرية لتكنولوجيا التعليم

أثرف أحمد عبداللطيف مرسي (Y V P أبريل). أثر التفاعل بين نمطي عرض وتوقيت الإنفوجرافيك في بيئة التعلم الإكتروني على التحصيل والاتجاه نحو بيئة التعلم لاى طلاب المرحلة الثانوية، العلوم التربوية.

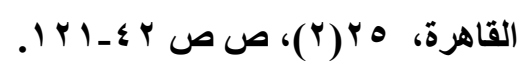

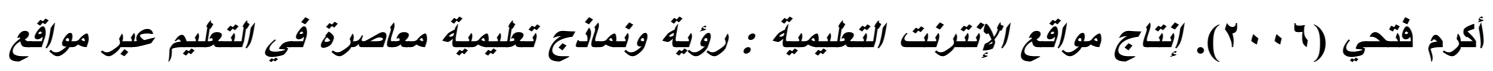

$$
\text { الإنترنت . القاهرة: عالم الكتب. }
$$

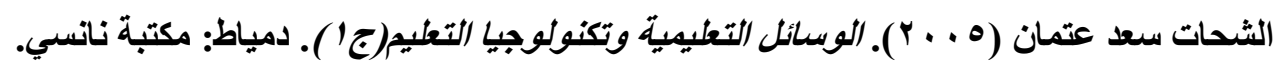

أمل شعبان أحمد خليل (7 1 • يوليو). أنماط الإنفوجرافيك التعليمي "الثابت/المتحرك/التفاعلي" وأثره في التحصيل وكفاعة تعلم الرياضيات لاى تلاميذ المرحلة الابتدائية ذوي الإعاقة الذهنية البسيطة، مجلة كلية

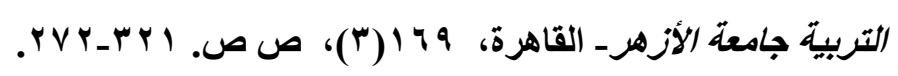

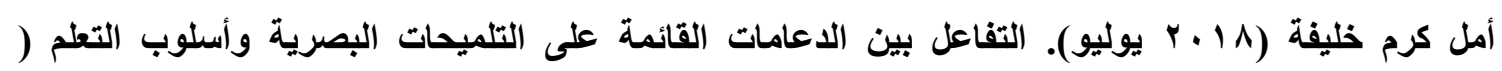
السطح//العميق ) وأثره في تنمية ممارسة الأنثطة الإكترونية وكفاءة التعلم ومهارات التفكير ما وراء

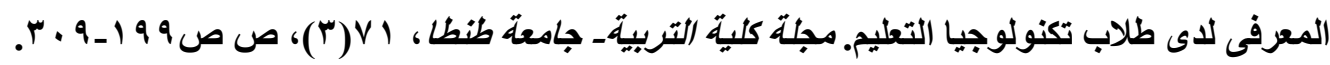

أميرة محمد المعتصم محمد غنيمي الجمل (• ( · ). أثر التفاعل بين أنماط القوائم في التعليم الإلكترونسي القائم على صفحات الويب وأسلوب التعلم على تنمية التحصيل وزمن التعلم والقابلية للاستخدام (دكتوراه، غير منشورة). كلية البنات، جامعة عين شمس.

أنور محمد الثرقاوي، وسليمان الخضري الثيخ (9^^ (1) ). اختبار الأثكال المتضنة (الصورة الجمعية): كراسة التعليمات ـ القاهرة: مكتبة الأنجلو المصرية.

أنور محمد الثرقاوي (990 (9) ). الأساليب المعرفية في بحوث علم النفس العربية وتطبيقاتها في التربية. القاهرة: مكتبة الأنجلو المصرية.

أنور محمد الثرقاوي (9 9 ( ) ). الإدراك فى نماذج تكوبين وتناول المعلومات ، مجلة علم النفس، القاهرة: الهيئة المصرية العامة للكتاب.

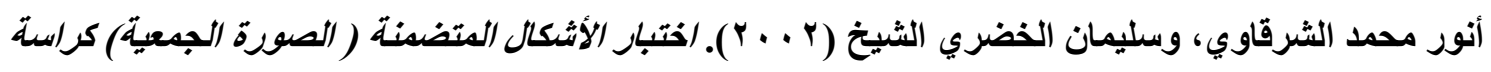
التعليصات. ( طه). القاهرة: مكتبة الأنجلو المصرية

91

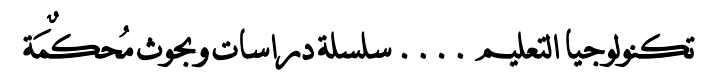


أنور محمد الثرقاوي (ץ . . ץ). علم النفس المعرفي المعاصر (طץ). القاهرة: مكتبة الأنجلو المصرية. إيمان جمال (1 ا • rيوليو). أنماط الاعم الإكتروني في بيئة التعلم النقال وأثره على تنمية بعض مهارات برمجة قواعد البيانات لاى طلاب تكنولوجيا التعليم. تكنولوجيا التربية: سلسلة دراسات ويحوث محكمة (َسم)، ص صץ ؟ ا ـ ـ ـ r. القاهرة: الجمعية العربية لتكنولوجيا التربية

إيمان صلاح الدين صالح (r ا • ب يناير). أثر التفاعل بين التلميحات البصرية والأسلوب المعرفي في الكتاب الإكتروني على التحصيل المعرفي والأداء المهاري وسهولة الإستخدام لدى تلاميذ المرحلة الثانية من

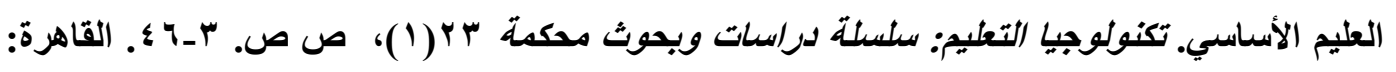
الجمعية المصرية لتكنولوجيا التعليم.

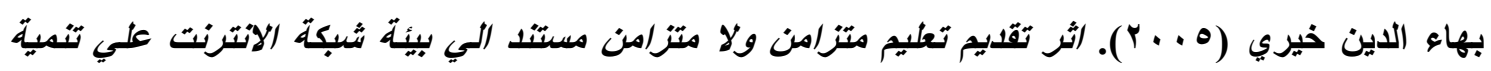

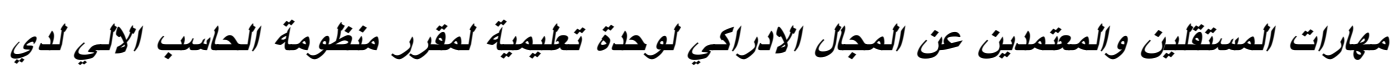
طلاب شعبة معلم الحاسب بكليات تربية نوعية (رسالة ماجستير، غير منشورة). معهد الدراسات التربوية، جامعة القاهرة.

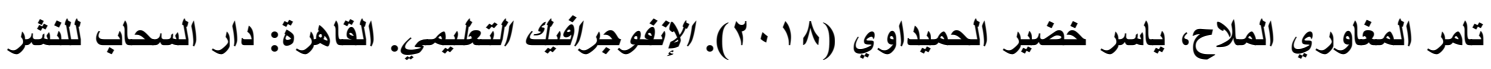
والتوزيع. حسن شحاتة، زينب النجار(r . ․ r). معجم المصطلحات التربوية والنفسية: عربي- انجليزي، انجليزي- عربي. القاهرة: الدار المصرية اللبنانية. حنـان أحمد عبد الله (• ( ب). العلاقة بين أسلوب عرض الأمثلـة والتلميحات البصرية فـي برامج الكمبيوتر التعليمية وبين تصحيح التصورات الخاطئة عن المفاهيم في العلوم لتلاميذ مرحلة التعليم الأساسسي (رسـالة ماجستير، غير منشورة). كلية التربية: جامعة حلوان.

حمدي على الفرماوي (ء 9 ( ) ). الأساليب المعرفية: بين النظرية والبحث. القاهرة: مكتبة الأنجلو المصرية. حمادة محمد مسعود، أيمن محمد عبدالهادي (17 ب أكتوبر). أثر استخدام الدعم الإكتروني في التعلم النقال على تنمية مهارات البحث في مصادر المعلومات الإكترونية لدى طلاب الدراسات العليا بكلية التربية. المجلة الدولية للعلوم التريوية والنفسية IJEPS : سلسلة دراسات ويحوث محكمة ع (1)، ص ص. 
الجمعية المصرية لتكنولوجيا التعليم

خالد محمد فرجون ( • • (Y). خطوة لتوظيف التعلم المتنقل بكليات التعليمي التطبيقي بلولة الكويت وفق مفهوم

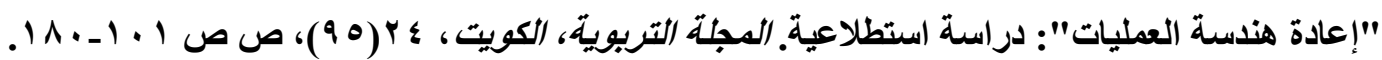
خليل ميخائيل معوض (99 (99). قدرات وسمات الموهوبين "ادراسة ميدانية" (طץ). القاهرة: مكتبة الأنجلو

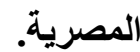

رفيق سعد البربري، حنان رجاء عبدالسلام (1 1 ـ ץ إبريل). فاعلية برنامج تدريبي مقترح قائم على تكنولوجيا التعلم المتنقل في علاج الأخطاء التدريسية الثائعة لاى معلمي المرحلة الثانوية. تكنولوجيا التعليم:

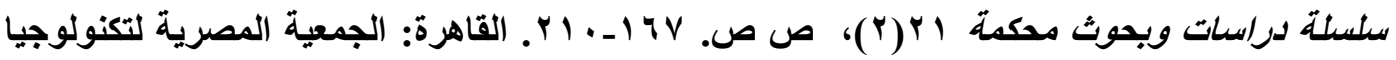
التعليم.

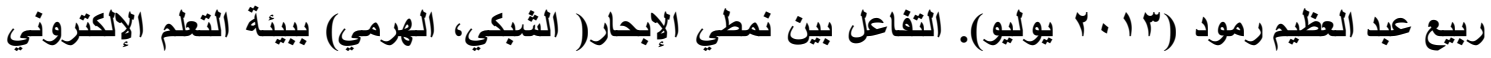
وأسلوب التعلم وأثر ذلك في التحصيل وتنمية مهارات تصميم صفحات الويب التعليمية لاى طلاب كلية التربية.

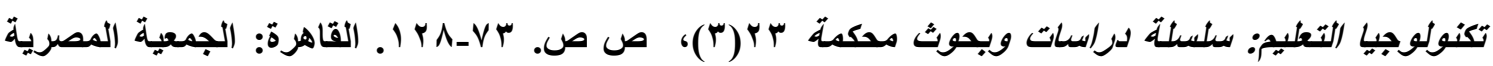
لتكنولوجيا التعليم.

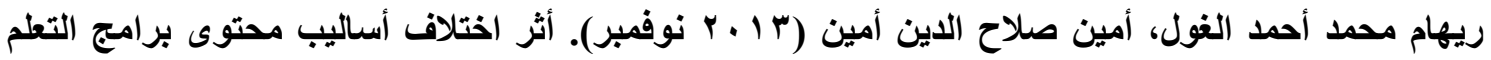
المتنقل على تنمية مهارات إنتاج البرامج الإكترونية التفاعلية لاى أعضاء هيئة التدريس. المناهج وطرق

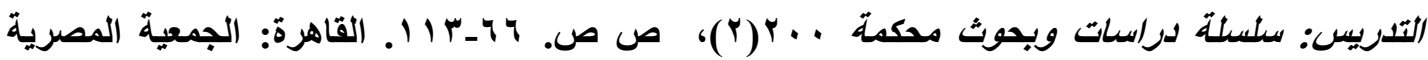
للمناهج وطرق التدريس. زينب حسن حامد السلامي (1 . ․ r). أثر التفاعل بين نمطين من سقالات التعلم وأسلوب التعلم عند تصديم برامج الكمبيوتر متعلدة الوسائط علي التحصيل وزمن التعلم ومهارات التعلم الذاتي لدى الطالبات المعلمات (رسالة دكتور اه، غير منشورة). كلية (البنات، جامعة عين شمس.

زينب محمد أمين (10 + r). المستحثثات التكنولوجية رؤي وتطبيقات. القاهرة: المؤسسة العربية للعلوم و الثقافة.

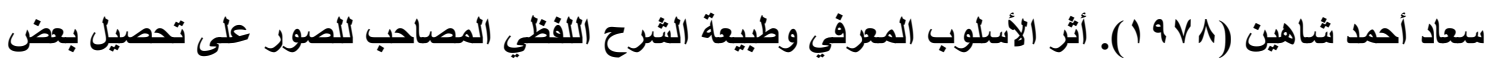
المعلومات العلمية لاى طلاب شعبتي التاريخ والفلسفة بكلية التربية جامعة طنطا (رسالة دكتوراه، غير منشورة). كلية التربية، جامعة طنطا.

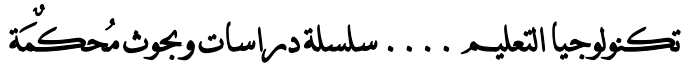


سعاد أحمد شاهين (V . . . يناير). أثر التخصص الأكاديمي والأسلوب المعرفي علي تصميم و إنتاج ملف الإنجاز الإكتروني E-Portfolio لدى الطلاب المعلمين بكلية التربية. تكنولوجيا التعليم: سلسلة دراسات

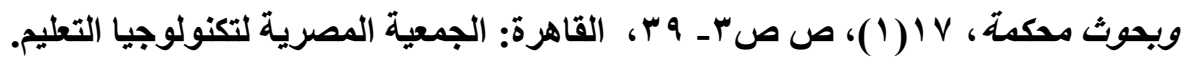

سماء عبد الفتاح عبد العزيز (r I ب ). أثر التلميحات البصرية لعروض الوسائط المتعلدة للمعاقين سمعيا على تنمية مهارات استخد/م برامج الحاسب الالمي ( رسالة ماجستير). كلية تربية، جامعة الفيوم. سماح عاطف محمد (V . . . . معايير تصميم المثيرات البصرية بكتب المواد الأدبية وفاعليتها في التحصيل الدراسي لطلاب المرحلة الثانوية ( رسالة ماجستير). كلية تربية، جامعة حلوان. سهام بنت سليمان محمد الجريوي (ع ا ب يناير). فعالية برنامج تدريبي مقترح في تنمية مهارات تصميم الخرائط الذهنية الإكترونية من خلال تقنية الإنفوجرافيك ومهارات الثقافة البصرية لاى معلمات قبل

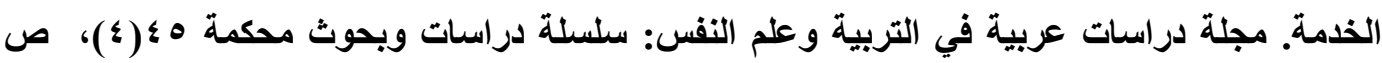

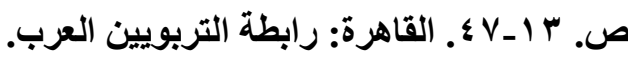
سيد خير الله (1919 1). اختبار القرة على التفكير الابتكارى، القاهرة: عالم الكتب. شاكر عبد الحميد (999 (19). دور الأخصائص النفسي في الكثف عن الواعدين بالإبداع في السباق التربوي. القاهرة: مركز البحوث والاراسات النفسية، الدورة التأسيسية الأولى للأخصائي النفسي. شريف أحمد إبراهيم محمد (0 . . Y). فاعلية اختلاف زوايا التصوير التلفزيوني في تنمية مهارات إنتاج بعض النماذج لاى طلاب شعبة تكنولوجيا التعليم المعتمدين والمستقلين علي المجال الإدراكي (رسالة ماجستير، غير منشورة). كلية التربية، جامعة الأزهر. شيرين سعد عبد العزيز(11 (Y). فعالية أنماط التلميح البصري في برامج الكمبيوتر التعليمية على تنمية تمييز الحروف الهجائية والكلمات لاى أطفال الروضة (رسالة ماجستير، غير منشورة). كلية التربية، جامعة حلوان.

صافي حسين مصطقى عبد الحميد (10 ب (10). التلميحات المكتوبة والمسموعة المصاحبة للألعاب التعليمية المستخدمة في التعلم الاكتروني وأثرها على التحصيل وتنمية مهارات حل المشكلات لاى تلاميذ المرحلة الإعدادية (رسالة ماجستير، غير منشورة). كلية التربية النوعية، جامعة المنوفية. 
الجمعية المصرية لتكنولوجيا التعليم

طلال شعبان عامر ( 1 . . Y). فعالية استخدام تكنولوجيا الوسائط المتعددة لإظهار البعدين الثانس والثالث فى حالتى السكون والحركة على التفكير الابتكارى لطلاب كليات التربية واتجاهاتهم نحو الرياضيات (رسالة دكتوراه،

غير منشورة). كلية التربية، جامعة المنوفية.

عادل عبدالرحمن، عبير عادل السيد، إيناس عبدالرعوف سيد (7 1 ـr يناير). دراسة تحليلية للإنفوجرافيك ودوره في العملية التعليمية في سياق الصياغات التثكيلية للنص (علاقة الكتابة بالصورة)، مجلة بحوث في

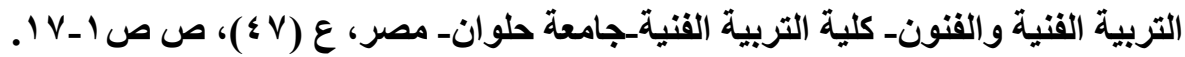
عاصم محمد إبراهيم (7 1 ـ ب يوليو). فاعلية استراتيجية مقترحة قائمة على الإنفوجرافيك فى اكتساب المفاهيم العلمية وتنمية مهارات التفكير البصري والاستمتاع بتعلم العلوم لاى تلاميذ الصف الخامس الإبتائي، مجلة

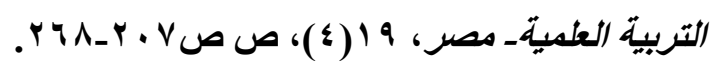

عبدالرحمن أحمد سالم (· ( + ( ). تصميم وإنتاج أنماط مختلفة من المساعدة والنصح في برامج المحاكاة الكمبيوترية التعليمية للتظلب على الإحباط ومواصلة التعلم في ضوء احتياجات الطلاب شعبة معلم الحاسب الآلي، دراسات ويحوث المؤتمر العلمي السادس بعنوان العلول الرقمبة لمجتمع التعلم لـ ــ نوفصبر: الجمعية العربية لتكنولوجيا التربية. عبد الستار إبراهيم (1 9 ( ). ثلاثة جوانب من التظور في دراسة الابلاع ـ القاهرة: عالم القكر. عبد الله سليمان، فؤاد أبو حطب ( • V ( ). اختبارات تورانس للتفكبير الابتكارى، القاهرة : دار المعارف. عبدالله عيد مسيعيد الرشيدي (r I ب r). أثر اختلاف توقيت عرض التلميح البصري في برامج الحاسوب متعلدة الوسائط على التحصيل الفوري والمرجأ للمفاهيم الرياضية لدي تلاميذ الصف الرابع الابتدائسي (رسالة ماجستير، غير منشورة). جامعة طيبة، المملكة العربية السعودية. عصام علي الطيب، ربيع عبده رشوان († + . ץ). علم النفس المعرفي - الذاكرة وتثثفير المعلومات، القاهرة: عالم الكتب. عصام شوقي شبل (צ 1 (Y). أثر بعض أساليب التوجيه الخارجي لبيئة تعلم فائقة قائمة على الويب على نواتج التعلم و الحمل المعرفي للتلاميذ المعتمدين و المستقلين عن المجال الإداركي. مجلة كلية التربية-جامعة

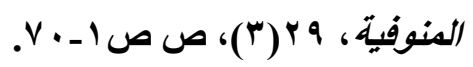


عمرو محمد أحمد درويش، وأماني أحمد محمد عيد الاخني (10 ب إبريل). نمطا تقديم الإنفوجرافيك (الثابت/المتحرك) عبر الويب وأثرها في تنمية مهارات التفكير البصري لاى أطفال التوحد واتجاهاتهم

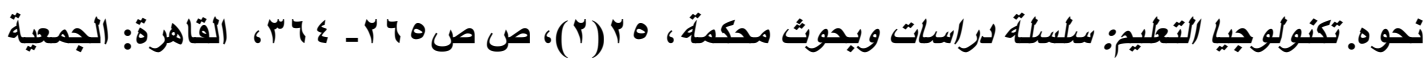
المصرية لتكنولوجيا التعليم.

ماريان ميلاد منصور (10 ـ ا أكتوير). أثر استخدام الإنفوجرافيك القائم على نموذج أبعاد التعلم لمارزانو على تنمية بعض مفاهيم الحوسبة السحابية وعادات العقل المنتج لاى طلاب كلية التربية. مجلة كلية التربية-

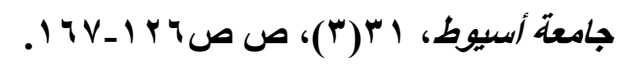

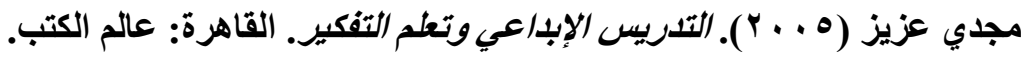

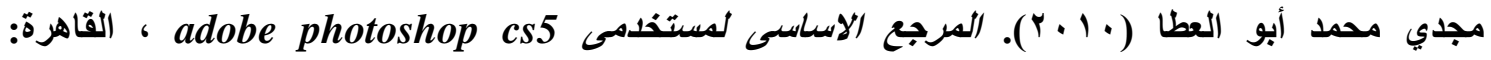
كمبيوساينس.

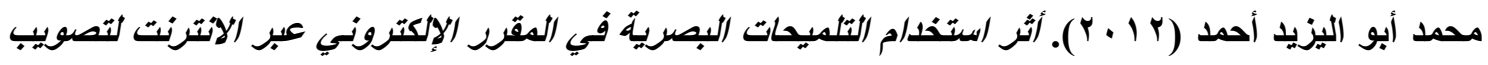
الأخطاء النحوية الشائعة في كتابات تلاميذ الهرحلة الإعدادية (رسالة ماجستير، غير منشورة). كلية تربية، جامعة حلوان. محمد الصاوي الفقي (9 . . . ). إنتاج الصور الفوتوغرافية. القاهرة: مطبعة أبناء وهبه وحسان. محمد سالم حسين درويش (7 1 ـ بمايو). فعالية استخدام الإنفوجرافيك على تعلم الأداء المهاري والتحصيل المعرفي لمسابقة الوثب الطويل. المجلة العلمية للتربية الرياضية والبلنية: سلسلة دراسات ويحوث

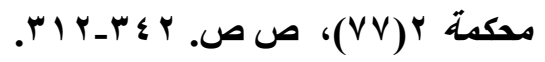
محمد عطية خميس (r . . . Y). عمليات تكنولوجيا التعليم. القاهرة: دار الكلمة.

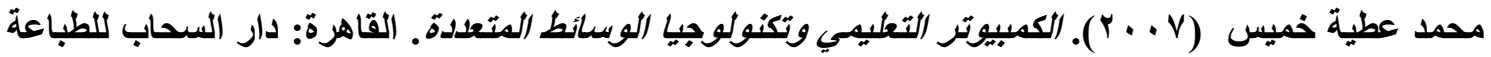
والنشر والتوزيع.

محمد عطية خميس (9 . . ץ). تكنولوجيا التعليم والتعلم. القاهرة: دار السحاب للطباعة والنشر والتوزيع. محمد عطية خميس (11 + (1). الأصول النظرية والتاريخية لتكنولوجيا التعلم اللإِكترونسي. القاهرة: دار السحاب للطباعة والنشر والتوزيع. 
الجمعية المصرية لتكنولوجيا التعليم

محمد عطية خميس (r Y P Y). النظرية والبحث التربوي في تكنولوجيا التعليم. القاهرة: دار السحاب للطباعة والنشر والتوزيع.

محمد عطية خميس (0 1 • Y). مصادر التعلم الإكترونسي : الأفراد والوسائط. الجزء الأول. القاهرة: دار السحاب للطباعة والنشر والتوزيع. محمد عطية خميس (1 I • ץ). بيئات التعلم الإكترونسي، ج ا. القاهرة: دار السحاب. محمد دسوقي موسى، مصطفى أبوالنور مصطفى (\& 1 (Y). فاعلية برنامج تدريبي قائم على دمج التعلم الإكتروني السحابي والمتنقل في تنمية مهارات استخدام بعض تطبيقات الهواتف الذكية في التعليم لاى معلم التعليم الأساسي. المؤتمر العلمي الرابع عشر بغنوان تكنولوجيا التعليم والتلريب الإكترونسي عن بعد

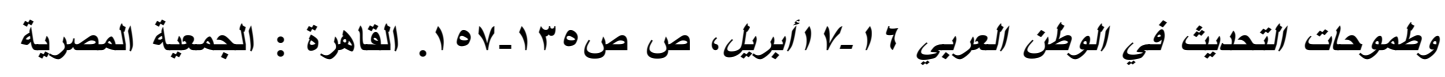
لتكنولوجيا التعليم. محمد محمد السعيد نعيم (q . . ץ). أثر التفاعل بين أنماط التعلم الإكتروني والأساليب المعرفية للطلاب على بعض نواتج التعلم. (رسالة دكتوراه غير منشورة)، معهد الدراسات التربوية، جامعة القاهرة. محمد محمود محمد أحمد (1^ • r). تصميم بيئة تعلم عبر الويب قائمة على الإنفوجر افيك الثابت (الرأسي-الأققي) وأثرها في تنمية مهارات تصميم واجهات المستخدم لاى طلاب قسم علم المكتبات. المؤتمر العلمي الرابع

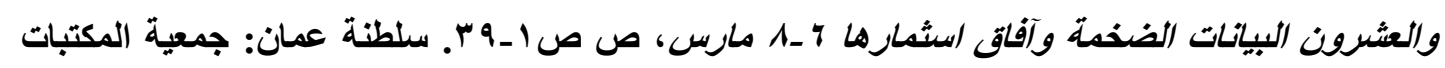
المتخصصة فرع الخليج العربي.

مختار عبدالخالق عطية (؟ 1 ـ ب يوليو). اتجاهات طلاب اللغة العربية كلغة ثانية نحو التعلم الجوال وحاجاتهم

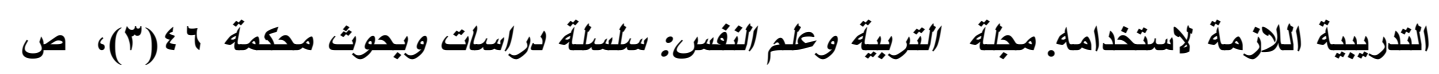

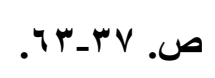

مصطفى سويف ( • V V ) ). الأسس الفنية للإبداع الفني في الثعر خاصة. القاهرة: دار المعارف.

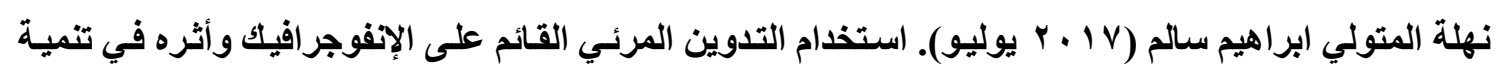

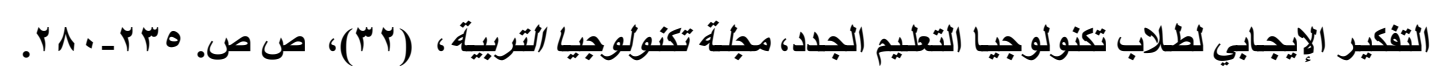
القاهرة: الجمعية العربية لتكنولوجيا التربية. 


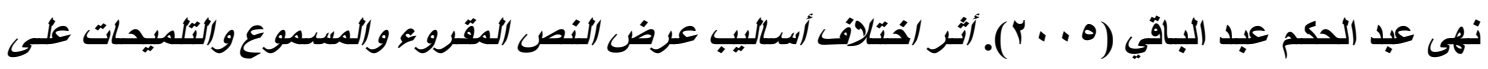
الشاثة التليفزيونية في برامج محو الأمية على التحصيل (رسالة ماجستير). كلية التربية، جامعة حلوان . ليلى الجهني (r ا ـ Y). فاعلية التعلم المتنقل عبر الرسائل القصيرة في تدريس بعض مفاهيم التعليم الإكتروني وموضوعاته لطالبات دراسات الطفولة. المؤتمر الدولمي الثالث للتعليم الإلكترونسي والتعلم عن بعد ؟_ V-

$$
\text { فبراير. الرياض : المركز الوطني للتعليم الإكتروني. }
$$

لولوه الدهيم (7 1 • بيوليو). أثر دمج الإنفوجر افيك في الرياضيات على تحصيل طالبات الصف الثاني المتوسط.

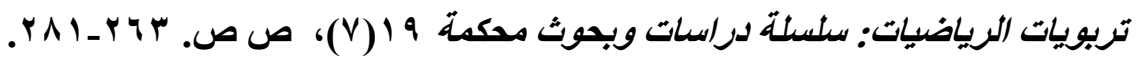

هاشم سعيد الثرنوبي (r I Y Y). فاعلية توظيف الثبكات الإجتاعية عبر الانترنت المصاحبة للمواقع التعليمية وأنماط الرسائل الاكترونية في التحصيل وتنمية مهارات تثغيل واستخدام الأجزة التعليمية الحديثة والقيم الأخلاقية الاكترونية لاى طلاب تكنولوجيا التعليم بكلية التربية. مجلة بحوث دراسات عربية فى

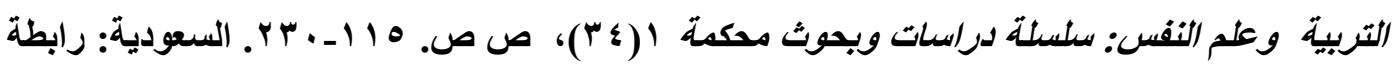
التربويين العرب.

هانى شفيق رمزى (Y 1 ـ ץ). فاعلية نظام إدارة المحتوى الاككترونى القائم على الهاتف النقال فى تنمية بعض مهارات استخدام المستحدثات التكنولوجية لاى معلمى المرحلة الاعدادية. مجلة بحوث عربية فى مجالات

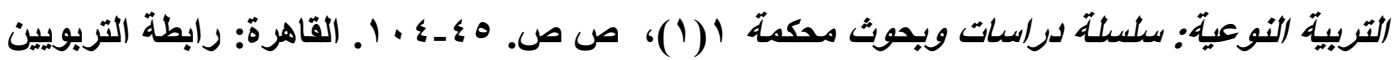

$$
\text { العرب. }
$$

هبه عثمان فؤاد العزب (r I † r). العلاقة بين التغذية الراجعة (موجزة، مفصلة) وأسلوب التعلم ببيئات التعلم الشخصية على تنمية التحصيل المعرفي والأداء المهاري والتنظيم الذاتي لدى طلاب تكنولوجيا التعليم (رسالة دكتوراه، غير منشورة). كلية البنات، جامعة عين شمس.

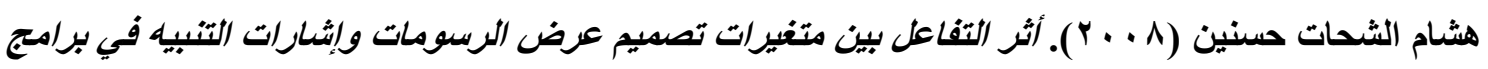
الحاسب الآلي التعليمية على تنمية التحصيل وتعديل اتجاهاتهم نحو تعلم الرياضيات (رسالة ماجستير، غير منشورة). كلية تربيه، جامعة حلوان. هشام محمد الخولي (r . . . Y). الأساليب المعرفية وضو/بطها في علم النفس. القاهرة: دار الكتاب الحديث. وليد سالم الحلفاوي (11 + ( ). التعليم الإكترونسي: تطبيقات مستحدثة. القاهرة: دار الفكر العربي. 
الجمعية المصرية لتكنولوجيا التطليم

$$
\text { يوسف قطامي (9 9 } 9 \text { ) ). سبكلوجية التعليم والتعلم الصفي. عمان: دار الثروق. }
$$

Attewell, J.(2005).Mobile Technologies and Learning. London: TRIBAL

Beale, I. (2005). Scaffolding and integrated assessment in computer assisted (CAI) for children with learning disabilities. Australasian Journal of Educational Technology, 21(2), pp. 173-191. http://www.ascilite.org.au/ajet21/BEALe.html

Berith, L., A.; Martin, L., J.; Ulrik Kold; \& Mikael, B. S. (2006). ISocialize: Investigating Awareness Cues For a Mobile Social Awareness Application. In OZCHI

https://pdfs.semanticscholar.org/b936/2d6d1c1ac76ecdb025f381e160d64ad2442 0.pdf

Brashears, M.T., Akers, C., Smith, J. (2005). The Effects of Multimedia Cues on Student Cognition in an Electronically Delivered High School Unit of Instruction. Southern Journal of Agricultural Education Research, 55(1), pp. 518.

Brashears, T., \& Baker, M. (2008). A Test of the Cue Summation Theory on Student Post-Test and Satisfaction in an Electronically- Delivered Unit of Instruction. NACTA Journal, 52(2), pp. 8-14.

Brashears, M.T., Fraze, S., \& Lawver, D. (2005). The Effects of Cue Summation on Student Cognition and Satisfaction in an Electronically-Delivered Secondary Agricultural Sciences Unit of Instruction. Proceedings of the Western Region Agricultural Education Research Conference, April 20-22, Prescott, AZ. 
Boucheix, J. M., Lowe, R. K., Putri, D. K., \& Groff, J. (2013). Cueing animation: Dynamic signaling aids information extraction and comprehension. Learning and Instruction, 25, pp.71-84.

Caudill, J.G. (2007). The Growth of M-Learning and the Growth of Mobile Computing: Parallel Developments. The International Review of Research in Open and Distance Learning, 8(2),pp. 1-13.

Chang, C., wong, w., \& chang, C. (2011). Integration of Project-Based Learning Strategy with Mobile Learning: Case Study of Mangrove Wetland Ecology Exploration Project, Tamkang, Journal of Science and Enginering, 14(3), pp. 265-274.

Chen,Y.S.; Kao, T.C. \& Sheu, J.P. (2003). A mobile learning system for scaffolding bird watching learning. Journal of Computer Assisted Learning, 19, pp. 347-359.

Chen, S. Y., Magoulas, G. D. \& Dimakopoulos, D. (2005), A flexible interface design for Web directories to accommodate different cognitive styles. Journal of the American Society for Information Science and Technology. 56, pp. 70-83. doi: 10.1002/asi.20103

Chen, G., Chang, C. \& Wang, C. (2008). Ubiquitous Learning Website: Scaffold Learners by .Mobile Devices with Information-aware Techniques. Computers \& Education, 50, pp. 77-90.

Crompton, H. (2013). A Historical Overview of Mobile Learning: Toward learnercentered education. In Z. L. Berge \& L. Y. Muilenburg (Eds.), Handbook of mobile learning, pp. 3-14. Florence, KY: Routledge.

Crooks, S. M., Cheon, J., Inan, F., Ari, F., \& Flores, R. (2012). Modality and cueing in multimedia learning: Examining cognitive and perceptual explanations for the modality effect. Computers in Human Behavior, 28, pp. 1063-1071.

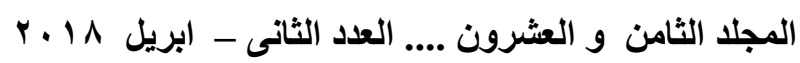
1. 
الجمعية المصرية لتكنولوجيا التعليم

Crompton, H., \& Burke, D. (2018). The use of mobile learning in higher education: A systematic review. Computers \& Education, 123, pp.53-64.

Dai, Siting (2014). Why Should PR Professionals EmbraceInfographics?, Faculty of the use Graduate School, Uniferisty Of Southern California.

Dean Ginther, Yuliang Liu (2002). Cognitive Styles and Distance Education. Journal of distance learning administration, 2(3).

De Koning, B. B., Tabbers, H. K., Rikers, R. M. J. P., \& Paas, F. (2007). Attention cueing as a means to enhance learning from an animation. Applied Cognitive Psychology, 21, pp. 731-746.

De Koning, B. B., Tabbers, H. K., Rikers, R. M. J. P., \& Paas, F. (2009). Towards a framework for attention cueing in instructional animations: Guidelines for research and design. Educational Psychology Review, 21, pp. 113-140.

De Koning, B. B., Tabbers, H. K., Rikers, R. M. J. P., \& Paas, F. (2011). Attention cueing in an instructional animation: The Role of presentation speed. Computers in Human Behavior, 27, 41-45.

Dwyer, F. (1978). Strategies for Improving Visiual Learning, Services, U.S.A.

Gehlbach, R. (1987). Creativity and instruction. Journal of Creative Behavior,1(22). 37.

Hamdan, Z. A. H. (2008). A Model for Designing And Adapting Mobile Learning Content, Master Thesis, Jordan, Middle East University for Graduate Studies.

Hanna, F., Z. (2017). The Effect of Mobile Learning on the Development of the Students' Learning Behaviors and Performance at Jordanian University. International Journal of Business and Management Invention. (6)3, 1-7. 
Johnston, K., A. (2016). The Use, Impact, and Unintended Consequences of Mobile Web-Enabled Devices in University Classrooms. Issues In Informing Science And Information Technology, 13, 25-46.

Iglesias, R., A.; García, R., B.; \& Sánchez, G., M., C. (2017). Collaborative learning and mobile devices: An educational experience in Primary. Education Computers in Human Behavior, v 72, p 664-677, July 1, 2017; ISSN: 07475632; DOI: 10.1016/j.chb.2016.07.019; Publisher: Elsevier Ltd

Fotouhi-Ghazvini, F.; Earnshaw , R. A.; Moeini, A.; Robison, D. \& Excell, P. S. (2011). From E-learning to M-learning - the use of mixed reality games as a new educational paradigm. IJIM, 5(2), pp. 17-25

Kim, K.-S. \& Allen, B. (2002), Cognitive and task influences on Web searching behavior. Journal of the American Society for Information Science and Technology, 53: pp. 109-119. doi: 10.1002/asi.10014

Kim, D., \& Gilman, D. A. (2008). Effects of Text, Audio, and Graphic Aids in Multimedia Instruction for Vocabulary Learning. Educational Technology \& Society, 11 (3), pp. 114-126.

King, K. P., \& Gura, M. (2007). Podcasting for Teachers: Using a new technology to revolutionize teaching and learning. Charlotte, NC: Information Age Publishing.

Kos, B. A., Sims, E. (2014): Infographics: The New 5-Paragraph Essay. In 2014 Rocky Mountain Celebration of Women in Computing. Laramie, WY, USA. .Infographics for Dummies. Wiley. http://site.ebrary.com/lib/sdl/reader.action?doclD=10882890\&ppg=17

Lester, P. M. (2006). Syntactic Theory of Visual Communication. From: http://paulmartinlester.info/writings/viscomtheory.html

المجلد الثامن و العشرون .... العدد الثانى - ابريل 1 1 ـ ب $1 \cdot r$ 
الجمعية المصرية لتكنولوجيا التعليم

Lin, L. (2011). Learning with Multimedia: Are Visual Cues and Self Explanation Prompta Effective?. Adissertation for the degree of doctor of philosophy. Arizona State University.

Lin, L.; \& Atkinson, R. K. (2011). Using animations and visual cueing to support learning and scientific concepts and processes. Computers and Education, 56, pp. 650-658.

Lin, I.,L.; Kuo, Y.,C; Lin, Y., C.; Lin, Y., C.; Chang, K., H.; \& Liu, T., C. (2012). Exploring the effect of "color cueing" on mobile learning in physical environments. Workshop Proceedings of the 20th International Conference on Computers in Education, ICCE 2012 2012, pp. 184-188.

Liu, T.; Lin, Y.; \& Paas, F. (2013). Effects of cues and real objects on learning in a mobile device supported environment. British Journal of Educational Technology, 44 (3), pp. 386-399.

Madsen, A.(2013). Studies of visual attention in physics problem solving. Kansas State University, Manhattan.

Matrix, S., \& Hodson, J. (2014). Teaching with infographics: Practicing new digital competencies and visual literacies. Journal of Pedagogic Development, 4(2). From: http://www.beds.ac.uk/jpd/volume-4-issue-2/teaching-with-infographics

Mautone, P. D., \& Mayer, R. E. (2001). Signaling as a cognitive guide in multimedia learning. Journal of Educational Psychology, 93, pp. 377-389. doi:10.1037/0022-0663.93.2.377.

Mileva, N. (2011). The effectiveness of mobile learning in the form of performance support system in higher education. (IJIM) International Journal of Interactive Mobile Technologies, 5(4), 17-21 
الجمعية المصرية لتكنولوجيا التعليم

Miller, G. A. (1956). The Magical Number Seven, Plus or Minus Two Some Limits on Our Capacity for Processing Information. Psychological Review, 101(2), pp. 343-352.

Oulasvirta, A., Petit, R., Raento, M., \& Tiitta, S. (2007). Interpreting and Acting on Mobile Awareness Cues. Human-Computer Interaction 22, pp. 97-135 (2007) 8. Carroll, J.M.

Pimmer, C.; Mateescu, M. ; Gröhbiel, U. (2016).Mobile and ubiquitous learning in higher education settings. A systematic review of empirical studies. Computers in Human Behavior, v 63, pp. 490-501, October 1, 2016; ISSN: 07475632; DOI: 10.1016/

Ryan, L. (2007). Advantage and Disadvantage of Mobile Learning . from:http://earticles.info/e/a/title/Advantages-and-Disadvantages-of-Mobile-Learning/

Roberts, W., E.(2009). The Use of Cues in Multimedia Instructions in Technology as a way to Reduce Cognitive Load (Doctoral dissertation). State University in partial fulfillment, Carolina.

Rogers, K., D. (2011). Mobile learning devices. Bloomington: A joint publication, Solution Tree and NAESP.

Salas Rueda, R. A. (2015). Use of infographics in virtual environments for personal learning process on boolean algebra. Revista de Comunicación Vivat Academia.130, pp. 37-47. DOI: http://dx.doi.org/10.15178/va.2015.130.64-74.

Semetko, H., \& Scammell, M. (2012). The SAGE Handbook of Political Communication, SAGE Publications.

Shih, Y. E. (2007). Dynamic language learning: Comparing mobile language learning with online language learning, PHD, United States- Minnesota, Capella University.

المجلد الثامن و العشرون .... العدد الثانى ـ ابريل 1 ـ r 
الجمعية المصرية لتكنولوجيا التعليم

Smiciklas, M. (2012). The power of infographics. Using Pictures to communicate and connect with your audiences. Estados Unidos, EU: Pearson

Tabbers, H. K., Martens, R. L., \& van Merriënboer, J. J. G. (2004). Multimedia instructions and cognitive load theory: Effects of modality and cueing. British Journal of Educational Psychology, 74, 71-81.

Terry, A. \& Fathi, E. (2004). Theory and practice of online learning. Athabasca university. From: http://cde.athabascau.ca/online_book/pdf/TPOL_book.pdf.

Tinajero, C. \& Paramo, M. F. (1997). Field Dependence- Independence and academic achievement. British Journal of Educational Psychology, pp. 67-78.

Ting, $T$ (2010). Web- based support system. Retrieved june,18,2012 from http://www.Booksgoogle.com.eg/Books?Isbn=1848826273

Thornton, P. \& Houser, C. (2005) Using mobile phones in English education in Japan. Journal of Computer Assisted Learning, 21, pp. 217-228.

Traintafillou E., Pomportsis, A., Demetriadis, s. \& Georgiadou, E. (2004). The value of adaptivity based on cognitive style: an empirical study. British journal of Educational Technology, 35(1), pp. 95-106.

Traxler,J. (2007). Defining, discussing and evaluating mobile learning: the moving finger writes and having writ, International Review of Research in Open and

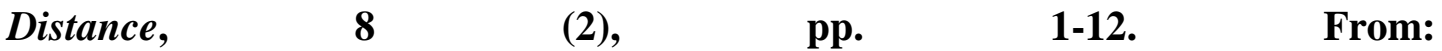
http://www.irrodl.org/index.php/irrodl/article/view/346/882

Torrance, E. P. (1972). Can We Teach Children To Think Creatively?. The Journal of Creative Behavior, 6, pp. 114-143. doi: 10.1002/j.21626057.1972.tb00923.x 
Voong, M. (2008). Contextual cues: Aiding wireless multimedia collaborative learning.Dimuat turun pada Februari 22, 2008 daripada. From: http://www.michaelvoong.com/documents/papers/michael_voongalpine_rendez-vous-contextual_cues.pdf

W3C (2017). Web content Accessibility Guidelines $2.0,24$.Web accessibility Initiative (WAI). From: http://www.w3.org/WAI/

Yang, H. Y. (2016). The Effects of Attention Cueing on Visualizers' Multimedia Learning. Educational Technology \& Society, 19 (1), p.p. 249-262.

Yang, S-H. (2012). Exploring College Students' Attitudes and Self-Efficacy of Mobile Learning. TOJET: The Turkish Online Journal of Educational Technology, 55(5), pp.552-575.

Zahariev, M. A., Christine, L., \& MacKenzie, ch. L. (2003). Auditory, Graphical and Haptic Contact Cues for a Reach, Grasp, and Place Task in an Augmented Environment. Canada: Simon Fraser University.

Zurita, G. \& Nussbaum, M. (2007). A conceptual Framework Based on Activity Theory for mobile CSCL. British Journal of Education Technology, 38(2), p.p. 211235.

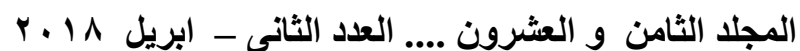

